Laura Rocha Prado

\author{
Taxonomia e análise cladística \\ de Cochabamba Bechyné, 1955 \\ (Coleoptera, Chrysomelidae, Galerucinae)
}




\author{
Laura Rocha Prado
}

\title{
Taxonomia e análise cladística de Cochabamba Bechyné, 1955 \\ (Coleoptera, Chrysomelidae, Galerucinae)
}

Dissertação apresentada ao Instituto de Biociências da Universidade de São Paulo, para a obtenção de Título de Mestre em Ciências, na Área de Zoologia.

Orientadora: Dra. Sônia Aparecida Casari

São Paulo 


Prado, Laura R.
Taxonomia e análise cladística de Cochabamba Bechyné,
1955 (Coleoptera, Chrysomelidae, Galerucinae)
88 páginas
Dissertação (Mestrado) - Instituto de Biociências da
Universidade de São Paulo. Departamento de Zoologia.
1. Taxonomia dos grupos recentes
2. Luperini
3. Diabroticites
I. Universidade de São Paulo. Instituto de Biociências.
Departamento de Zoologia.

Comissão Julgadora:

Dr.

Dr.

Dra. Sônia Aparecida Casari 
Aos meus pais 
Esas ambigüedades, redundancias y deficiencias recuerdan las que el doctor Franz Kuhn atribuye a cierta enciclopedia china que se titula Emporio celestial de conocimientos benévolos. En sus remotas paginas esta escrito que los animales se dividen en (a) pertenecientes al Emperador, (b) embalsamados, (c) amaestrados , (d) lechones, (e) sirenas, (f) fabulosos, (g) perros sueltos, (h) incluidos en esta clacificación, (i) que se agitan como locos, (j) innumerables, (k) dibujados con un pincel finísimo de pelo de camello, (l) etcétera, (m) que acaban de romper el jarrón, (n) que de lejos parecen moscas.

El idioma analítico de John Wilkins Jorge Luis Borges 


\section{Agradecimentos}

Gostaria de expressar meus sinceros agradecimentos a todos aqueles que contribuíram de maneira direta ou indireta para o desenvolvimento desse trabalho.

À minha família, pelo incentivo e suporte irrestritos, e em especial aos meus pais, pela generosidade, amor e por estimularem desde cedo a minha curiosidade (sempre oferecendo-me enciclopédias no lugar de respostas prontas).

À Dra. Sônia Casari, minha orientadora, pela confiança depositada em mim desde o primeiro dia de estágio em seu laboratório (quando eu ainda era botânica), pelos ensinamentos e por sempre estar disposta a auxiliar-me.

Ao Dr. Luciano Moura, por convencer-me a adotar os crisomelídeos logo no início da elaboração do projeto de pesquisa e pela ajuda inestimável e constante durante todo o período de trabalho.

Ao Dr. Carlos Roberto Brandão pelo acesso ao laboratório e ao Ricardo Kawada pelo auxílio na automontagem das fotografias dos hábitos dorsais.

À Dra. Simone Policena Rosa pelo asilo político em tempos de final de dissertação, pelas discussões, pela ajuda na investigação dos mistérios da análise cladística e pelas expedições de coleta ao cerrado.

Ao Fernando De Domenico e ao Guilherme Ide por tornar o meu relacionamento com o Photoshop mais simples e os momentos de procrastinação mais divertidos.

Aos ichtio-amigos, Carine Cavalcante e André Ferreira, pelo auxílio na confecção dos mapas.

À Dra. Cleide Costa, pelo acesso ao seu laboratório, sem o qual não seria possível confeccionar a automontagem das micrografias das genitálias estudadas.

À também crisomelidóloga, Flávia Fernandes, pelas discussões intermináveis (entomológicas ou não) e pela amizade.

Às funcionárias da biblioteca do MZUSP, em especial à Dione, Marta e Cláudia, por vasculharem os arquivos do MZUSP e do mundo atrás das publicações de que eu precisei e por (quase) nunca me importunarem pelos periódicos eternamente em atraso.

Ao Carlos Campaner por todo o auxílio com a coleção de Coleoptera do MZUSP.

Aos amigos de laboratório e de entomologia, Guilherme Ide (Gutto), Fernando De Domenico (Careca), Péterson Lopes (Jofre), Flávia Fernandes (Brasa), Ricardo Kawada (Cocadinha), Júlia Calhau de Almeida, Tiago Carrijo, Maurício Martins Rocha (Moura), Rodrigo Feitosa, Carlos Eduardo Sanhudo, Simeão Moraes, Lívia Pinheiro, Lucas Cezar, Paula Rodrigues, Ramon de Mello, pelo companheirismo, pelas discussões fundamentais e pelo cafezinho obrigatório no porão.

Às amigas ecólogas, Rachel Werneck, Denise Alves, Camila Mandai e Esther Gonzalez por tornarem os momentos de ansiedade e burocracia finais mais agradáveis.

Aos demais amigos de MZUSP, de IBUSP, de graduação (yo soy 04D) e de infância, 
pela amizade atemporal.

Meus agradecimentos, finalmente, ao Conselho Nacional de Desenvolvimento Científico

e Tecnológico e à Fundação de Amparo à Pesquisa do Estado de São Paulo, pelo apoio financeiro concedido, sem o qual a realização desse trabalho seria muito mais difícil. 


\section{Sumário}

$\begin{array}{ll}\text { Abstract } & 1\end{array}$

Resumo 2

1 Introdução 3

1.1 Família Chrysomelidae Latreille, $1802 \ldots$. . . . . . . . . . . . . . . . 3

1.2 Galerucinae s. s. X Galerucinae s. l. . . . . . . . . . . . . . . . . 4

1.3 Subfamília Galerucinae . . . . . . . . . . . . . . . . 5

1.4 Histórico do gênero Cochabamba Bechyné . . . . . . . . . . . . . 6

$\begin{array}{llr}2 & \text { Objetivos } & 7\end{array}$

3 Material e métodos $\quad 8$

3.1 Material-examinado . . . . . . . . . . . . . . . . . . . 8

3.1 .1 Material-tipo ................... 8

3.2 Estudo da morfologia . . . . . . . . . . . . . . . . . . . . . . . . . . 9

3.2 .1 Dissecções . . . . . . . . . . . . . . . . . . . . . 9

3.2 .2 Ilustrações . . . . . . . . . . . . . . . . . . . . . . . . . . . . . . . . 10

3.2.3 Redescrições e diagnoses . . . . . . . . . . . . . . . . . . . . . 10

3.3 Análise Cladística . . . . . . . . . . . . . . . . . . . . . . . 11

3.3 .1 Grupo-interno . . . . . . . . . . . . . . . . . . . . 11

3.3.2 Grupo-externo . . . . . . . . . . . . . . . . . . . 11

3.3.3 Levantamento e codificação de caracteres . . . . . . . . . . . . . . . 11

3.3 .4 Algoritmos . . . . . . . . . . . . . . . . . . . . . . . 12

3.3.5 Visualização das árvores e otimização dos caracteres . . . . . . . . . . 12

3.4 Terminologia - definições e comentários . . . . . . . . . . . . . . . . . . 12

3.4.1 Morfologia externa . . . . . . . . . . . . . . . 13

3.4 .2 Genitália masculina . . . . . . . . . . . . . . . . . . . . 14

3.4 .3 Genitália feminina . . . . . . . . . . . . . . . . . . 16

3.5 Distribuição geográfica . . . . . . . . . . . . . . . . . . 16

4 Resultados e discussão $\quad 17$

4.1 Análise cladística . . . . . . . . . . . . . . . . . . . . . . . . . 17

4.1 Topologias . . . . . . . . . . . . . . . . 17

4.1 .2 Lista de caracteres . . . . . . . . . . . . . . . . . 17

4.1.3 Monofilia de Cochabamba . . . . . . . . . . . . . . 26

4.1.4 Agrupamentos internos . . . . . . . . . . . . . . . . 26

4.1 .5 Grupo-irmão . . . . . . . . . . . . . . . . . 28

4.2 Taxonomia . . . . . . . . . . . . . . . . . . . . . . . 29 
4.2.1 Considerações taxonômicas . . . . . . . . . . . . . . . . . . . . . 29

4.2.2 Redescrição e discussão dos caracteres do gênero Cochabamba . . . 30

Chave de identificação para as espécies de Cochabamba Bechyné, 195534

4.2.3 Redescrição e discussão dos caracteres das espécies do grupo-interno

e descrição de espécie nova . . . . . . . . . . . . . . . . . 36

Cochabamba chacoensis (Bowditch, 1911) . . . . . . . . . . 36

Cochabamba chrysopleura (Harold, 1875) . . . . . . . . . . 38

Cochabamba diversicolor (Baly, 1890) . . . . . . . . . . . . . . 40

Cochabamba erythrodera (Baly, 1879) . . . . . . . . . . . 41

Cochabamba marginata (Harold, 1875) . . . . . . . . . . . 43

Cochabamba mera Bechyné, 1956 . . . . . . . . . . . . . 47

Cochabamba polychroma Bechyné, 1956 . . . . . . . . . . . . 48

Cochabamba rufolimbata (Baly, 1879) comb. nov. . . . . . . . . 50

Cochabamba rugulosa (Baly, 1886) . . . . . . . . . . . . 52

Cochabamba variolosa (Jacoby, 1878) . . . . . . . . . . . 53

Cochabamba sp. nov. . . . . . . . . . . . . . . 54

Espécie excluída de Cochabamba . . . . . . . . . . . 55

$\begin{array}{lll}5 & \text { Conclusões } & 57\end{array}$

6 Referências bibliográficas $\quad 58$

7 Apêndices $\quad 64$

\section{Tabela}

1 Matriz de dados morfológicos . . . . . . . . . . . . . . 64

\section{Figuras}

1 Cladograma de consenso obtido a partir das árvores mais parcimoniosas com pesos iguais . . . . . . . . . . . . . . . . . . 65

2 Cladogramas resultantes da busca exaustiva com pesagem sucessiva dos caracteres . . . . . . . . . . . . . . . . 66 66

3 Cladograma de consenso obtido a partir das árvores mais parcimoniosas com pesagem sucessiva dos caracteres . . . . . . . . . . . . . . 67

4 Cladograma resultante da busca exaustiva com pesos iguais, excluindo-se o grupo-externo Paranapiacaba teinturieri . . . . . . . . . . . . . . . . 68

5 Diagramas esquemáticos . . . . . . . . . . . . . . . . . . 69

6 Cabeças, diagramas esquemáticos e vista frontal de Cerotoma variegata . . 70 
7 Cabeças, vista frontal . . . . . . . . . . . . . . . 71

8 Cabeças, vista frontal . . . . . . . . . . . . . . . . . . 72

9 Antenas, vista lateral . . . . . . . . . . . . . . . . 73

10 Pronotos . . . . . . . . . . . . . . . . . . . . . 74

11 Pronotos . . . . . . . . . . . . . . . . . . 75

12 Hábitos dorsais . . . . . . . . . . . . . . . . . . . 76

13 Hábitos dorsais . . . . . . . . . . . . . . . . . . . . . . . . . . 77

14 Élitros esquerdos, em vista dorsal . . . . . . . . . . . . . . . 78

15 Micrografias eletrônicas de varredura (C. marginata $)$. . . . . . . . . . 79

16 Micrografias eletrônicas de varredura $($ C. marginata $)$. . . . . . . . . 80

17 Lobos-médios . . . . . . . . . . . . . . . . . . . . . . . . 81

18 Região central esclerotizada da bursa copulatrix . . . . . . . . . . . . . . . 82

19 Palpos vaginais . . . . . . . . . . . . . . . . . . . . . . 83

20 Espermatecas .......................... 84

21 Esternito VIII (spiculum ventrale) . . . . . . . . . . . . . . . . 85

22 Estruturas sem variação inter-específica no gênero Cochabamba . . . . . . . 86

23 Distribuição geográfica das espécies de Cochabamba e Paranapiacaba volxemi 87

24 Distribuição geográfica das espécies de Cochabamba e Paranapiacaba volxemi 88 


\begin{abstract}
Cochabamba Bechyné, 1955 is a strictly neotropical genus, recorded only from Central and South America. This genus belongs to the Galerucinae diabroticines, a group which includes well studied taxa of economic importance, but has a poorly understood systematics. The present study provides the first revisional and cladistic treatment of this group, up to now composed by 10 species. The morphological study of all specimens followed the traditional methods of dissection and illustration of specimens (at least one male and female of every species, if available). The cladistic analysis was based on 15 terminal taxa and 58 morphological characters (including 5 referring to coloration and 13 to genitalia). Since there were no previous phylogenetic hypothesis for the relationships of this genus, the outgroups were selected among the representatives of the subfamily Galerucinae. The analysis using equally weighted characters produced 13 equally most-parcimonious trees $(\mathrm{L}=102)$, which resulted in a consensus diagram 108 steps long. The analysis conducted after sucessive weighting of characters found 3 most-parcimonious trees, which resulted in a consensus diagram 103 steps long (CI= $74 ; \mathrm{RI}=60$ ). According to the observed topologies, Cochabamba as previously defined is a merophyletic group. To recover its monophyly, the taxon C. volxemi must be transferred back to genus Paranapiacaba Bechyné, 1955 (reinstated combination) and Diabrotica rufolimbata (new combination) included into the genus. An identification key to species is presented, as well as the redescription of all 11 Cochabamba species, including the description of a new species. Maps showing the geographic distribution of the species are also presented, based on the labels of studied material and data collected from literature.
\end{abstract}

Keywords: Hexapoda, systematics of Coleoptera, Diabroticites. 


\section{Resumo}

O gênero Cochabamba Bechyné, 1955 é estritamente neotropical, com registros de ocorrência confirmados apenas para a América Central e América do Sul. O gênero faz parte do grupo dos Galerucinae diabroticinos, o qual inclui táxons muito estudados por sua importância econômica, mas que, apesar disso, tem a sistemática pouco resolvida. Realizou-se a revisão taxonômica e a análise cladística do gênero, uma vez que não existia nenhum estudo desta natureza para o grupo que incluía, até o presente trabalho, 10 espécies. O estudo morfológico foi executado segundo protocolo tradicional, que inclui dissecção e ilustração dos espécimes (pelo menos um macho e uma fêmea de cada espécie, quando disponível). A análise cladística baseou-se em 15 terminais e 58 caracteres morfológicos (sendo 5 referentes à coloração, e 13 à genitália). Considerando a inexistência de informações filogenéticas para o gênero, os terminais do grupo externo foram selecionados dentre representanes da subfamília Galerucinae. A busca exaustiva com pesos iguais dos caracteres encontrou 13 árvores mais parcimoniosas $(\mathrm{C}=102)$, cujo consenso teve comprimento igual a 108 passos. A análise com pesagem sucessiva dos caracteres encontrou 3 árvores mais parcimoniosas $(\mathrm{C}=102)$, cujo consenso teve comprimento igual a 103 passos $(\mathrm{IC}=74, \mathrm{IR}=60)$. As topologias encontradas indicam que o gênero Cochabamba como configurado até o presente trabalho era merofilético. A monofilia de Cochabamba é recuperada com a transferência de C. volxemi para o gênero Paranapiacaba Bechyné, 1955 (combinação revalidada) e a inclusão de Diabrotica rufolimbata (nova combinação). Apresenta-se uma chave de identificação para as espécies de Cochabamba, além da redescrição de todas as espécies incluídas, bem como a descrição de uma espécie nova, o que resulta em 11 espécies. Apresentam-se, ainda, mapas indicando a distribuição geográfica do gênero, os quais foram confeccionados a partir de informações de localidade presentes nas etiquetas de cada exemplar examinado, além dos dados obtidos na literatura.

Palavras-chave: Hexapoda, sistemática de Coleoptera, Diabroticites. 


\section{Introdução}

\subsection{Família Chrysomelidae Latreille, 1802}

A família Chrysomelidae, incluída na subordem Polyphaga Emery, 1886, série Cucujiformia Lameere, 1938, superfamília Chrysomeloidea Latreille, 1802 (Crowson, 1967; Lawrence \& Newton, 1995), é constituída de besouros fitófagos de forma corporal e padrões de coloração extremamente variados, freqüentemente de coloração brilhante ou metálica (Riley et al., 2002).

Uma das maiores famílias de Coleoptera, Chrysomelidae compreende mais de 36.500 espécies descritas (Costa, 1999), número que, estima-se, passará de 60.000 se houver levantamentos faunísticos e estudos taxonômicos adequados (Reid, 1995). No Brasil foi registrada a ocorrência, provavelmente subestimada, de aproximadamente 4.200 espécies distribuídas em 345 gêneros (Costa, 1999).

Os crisomelídeos têm corpo relativamente pequeno, variando de 1,5-22,0 mm de comprimento. A cabeça é prognata ou hipognata e se encaixa parcial ou quase totalmente no protórax. As antenas são relativamente curtas (menores do que metade do comprimento do corpo), filiformes ou engrossando gradualmente da base até o ápice (raramente denteadas ou pectinadas), com 11 antenômeros. As pernas têm coxas anteriores globulares ou transversas e normalmente distintamente separadas, fêmures posteriores que podem ser dilatados para saltar (subfamília Alticinae) e tarsos pseudotetrâmeros com tarsômero III geralmente bilobado (Costa Lima, 1931; Crowson, 1981).

As larvas de Chrysomelidae têm morfologia bastante variada, sendo freqüentemente alongadas e encurvadas. Em geral têm cabeça defletida, antenas com 3 antenômeros (freqüentemente com 1-2 antenômeros), mandíbulas palmadas com 2-5 dentes na margem distal, sem mola; pernas torácicas bem desenvolvidas, próprias para a locomoção, com 5 segmentos ou menos (ou ausentes), pulvilo freqüentemente presente no tarsúngulo, espiráculos geralmente anulares (Lawson, 1987; Costa et al., 1988).

Os crisomelídeos têm hábitos fitófagos diversos, podendo alimentar-se de quase todas as partes vegetais, incluindo o sistema radicular subterrâneo (no estágio larval). Há espécies que se alimentam de plantas aquáticas ou de folhas mortas, outras que são minadoras de folhas ou formam galhas, e ainda outras que vivem como comensais em ninhos de formigas. A família tem grande importância econômica, uma vez que muitas de suas espécies são consideradas pragas agrícolas importantes por predarem ativamente diversos cultivares comuns, como tomate, batata, feijão e soja (Crowson, 1981; Costa Lima, 1931; Lawson, 1987; Riley et al., 2002).

A sistemática da família é controversa no que diz respeito ao número de subfamílias. O sistema de organização de Chrysomelidae proposto por Chapuis em 1874 considerava 15 "tribos", as quais representam a base para todas as classificações subseqüentes (Seeno 
\& Wilcox, 1982). Desde então, novos sistemas foram propostos baseados em caracteres variados, e o número de subfamílias oscilou, atingindo o número máximo de 18 (ver, por exemplo, Lawrence \& Newton, 1995). Estudos filogenéticos mais recentes indicam uma tendência na redução no número de subfamílias (Borowiec, 1995; Lawrence \& Newton, 1995; Reid, 1995; Farrell, 1998; Reid, 2000; Staines, 2002). Atualmente 11 subfamílias são aceitas: Bruchinae, Chrysomelinae, Criocerinae, Cryptocephalinae (incluindo Clytrinae e Chlamisinae), Donaciinae, Eumolpinae (incluindo Megascelidinae e Synetinae), Galerucinae (incluindo Alticinae), Cassidinae (incluindo Hispinae), Lamprosomatinae (incluindo Sphaerocharitinae), Sagrinae (Borowiec, 1995; Lawrence \& Newton, 1995; Reid, 1995; Staines, 2002) e Spylopirinae (Reid, 2000).

\subsection{Galerucinae $s . s . \mathrm{X}$ Galerucinae $s . l$.}

A sistemática de Galerucinae ainda está em ampla discussão e há várias hipóteses filogenéticas conflitantes. O principal problema em debate é o relacionamento entre Galerucinae e Alticinae, sua monofilia e status filogenético. Lingafelter \& Konstantinov (1999) revisaram o histórico da questão e reconheceram duas correntes principais, opostas, na classificação do grupo. Uma das correntes segue Newman (1835), que considerou Alticinae pela primeira vez como uma subfamília independente de Galerucinae e as duas subfamílias como grupos irmãos. A segunda corrente concorda com a classificação inicial do grupo, proposta por Latreille (1802), que trata os alticíneos como um subgrupo de Galerucinae.

$\mathrm{Na}$ última década, três principais hipóteses para o relacionamento entre alticíneos e galerucíneos foram propostas, fundamentadas por caracteres morfológicos e/ou moleculares:

1. Alticinae e Galerucinae como grupos-irmãos (Farrell, 1998; Farrell \& Sequeira, 2004; Gillespie et al., 2004; Gómez-Zurita et al., 2008);

2. Alticinae como agrupamento parafilético que incluiria os Galerucinae sensu stricto, grupo monofilético (Kim et al., 2003; Gillespie et al., 2003; Duckett et al., 2004; Bünnige et al., 2008; Gillespie et al., 2008);

3. Alticinae como um grupo monofilético, incluído em Galerucinae, grupo parafilético (Lingafelter \& Konstantinov, 1999).

No entanto, nenhuma das hipóteses mencionadas está livre de ressalvas (Reid, 2000) e o debate indica que a reconstrução da história evolutiva desses táxons está longe de ser trivial (Kim et al., 2003).

Tendo em vista a indefinição da posição sistemática dos alticíneos, a terminologia adotada aqui é coerente com a hipótese mais conservadora de classificação do grupo, que adota os termos Galerucinae e Galerucinae s. s. como equivalentes. 


\subsection{Subfamília Galerucinae}

A subfamília Galerucinae inclui aproximadamente 5.800 espécies distribuídas em 480 gêneros e cinco tribos: Oidini, Galerucini, Metacyclini, Sermylini e Luperini (Seeno \& Wilcox, 1982), e tem como características gerais: corpos ovais ou alongados; cabeça não inserida profundamente no protórax; antenas normalmente longas e aproximadas na base; olhos inteiros; élitros inteiros, aparentemente não fortemente esclerotizados; epipleuras elitrais simples ou ausentes; procoxas normalmente contíguas, fêmures posteriores de aspecto alongado (em oposição aos fêmures dilatados atribuídos aos Alticinae), tarsômero III bilobado (Costa Lima, 1931).

A tribo Luperini está dividida em três subtribos: Aulacophorina, Diabroticina e Luperina. A subtribo Diabroticina, com 40 gêneros, dos quais 32 são sul-americanos, é separada em quatro seções, a saber: Diabroticites, Cerotomites, Phyllecthrites e Trachyscelidites (Seeno \& Wilcox, 1982; Smith \& Lawrence, 1967). Essa subtribo neotropical é muito estudada por incluir diversas espécies de importância econômica para o homem (Costa Lima, 1931; Wilcox, 1965).

A principal característica que diferencia os diabroticinos dos demais Galerucinae é a presença de garras tarsais bífidas, com lobo interno estreito e afiado (Smith \& Lawrence, 1967; Riley et al., 2002). O gênero Cochabamba Bechyné está incluído na seção Diabroticites, que compreende todas as espécies que são ou já foram incluídas no gênero Diabrotica antes de 1947, o que resulta num total de 16 gêneros (Smith \& Lawrence, 1967; Seeno \& Wilcox, 1982).

O gênero Cochabamba, atualmente com 10 espécies, tem como principal caráter diagnóstico, segundo Bechyné (1955b), metepisterno coberto por pilosidade muito densa, que encobre completamente o esclerito, impossibilitando a visualização da sua escultura - a qual pode estar também presente em áreas vizinhas. Outros caracteres diagnósticos são: antenômero II curto, III pouco mais longo que o II e ambos juntos com comprimento igual ou maior à metade do comprimento do IV, espaço genal menor do que um quarto do máximo diâmetro ocular, tarsômero I das pernas protorácicas dos machos com órgão adesivo que ocupa apenas a sua porção basal (Bechyné \& Bechyné, 1962; Cabrera, 1999).

As larvas de Galerucinae em geral são ortossomáticas, de mandíbulas palmadas, com 4-5 dentes, antenas com 1-2 antenômeros, relativamente curtas, labro livre, com emarginação mais ou menos profunda, palpos maxilares com 3-4 palpômeros, palpos labiais com 2 palpômeros, abdômen com 9 ou 10 segmentos (Lawson, 1987). Não foram encontrados registros na literatura de quaisquer estágios imaturos de Cochabamba. Tampouco foi possível coletar larvas desse gênero durante o desenvolvimento desse projeto, apesar de diversas tentativas nesse sentido. 


\subsection{Histórico do gênero Cochabamba Bechyné}

O gênero Cochabamba foi criado em 1955 por Bechyné para incluir quatro espécies de Diabrotica Dejean: D. chrysopleura Harold, D. chacoensis Bowditch, D. marginata (Harold, 1875) e D. variolosa Jacoby. Diabrotica marginata (Harold, 1875), do Brasil (Rio de Janeiro), foi estabelecida como espécie-tipo do gênero. Em 1956, Bechyné transferiu para Cochabamba, Diabrotica rugulosa Baly e D. viridilimbata Baly e descreveu, ainda, C. polychroma e C. mera.

Smith \& Lawrence (1967), examinando o material-tipo de todas as espécies descritas à época em Diabroticites, incluíram em Cochabamba outras duas espécies pertencentes a Diabrotica: D. diversicolor Baly, 1890 e D. erythrodera Baly, 1879. Além disso, os autores, baseando-se no holótipo de C. viridilimbata (Baly, 1879), transferiram a espécie de volta ao gênero Diabrotica. Em 2003, Moura transferiu outra espécie de Diabrotica para Cochabamba: C. volxemi (Baly, 1889), anteriormente incluída em Synbrotica Bechyné, 1956 e depois em Paranapiacaba Bechyné, 1958 por Bechyné. Assim, as espécies atualmente incluídas em Cochabamba são:

1. C. chacoensis (Bowditch, 1911);

2. C. chrysopleura (Harold, 1875);

3. C. diversicolor (Baly, 1890);

4. C. erythrodera (Baly, 1879);

5. C. marginata (Harold, 1875) - espécie-tipo;

6. C. mera Bechyné, 1956;

7. C. polychroma Bechyné, 1956;

8. C. rugulosa (Baly, 1886);

9. C. variolosa (Jacoby, 1878);

10. C. volxemi (Baly, 1889).

O gênero apresenta distribuição estritamente neotropical, com ocorrências registradas apenas para a América Central e do Sul (Weise, 1924; Bechyné, 1955b, 1956; Smith \& Lawrence, 1967; Seeno \& Wilcox, 1982; Cabrera, 1999). A literatura encontrada para o gênero trata apenas das descrições originais específicas, novas combinações e citações em catálogos. Há ainda um estudo realizado por Cabrera (1999), cujo objetivo foi redescrever C. polychroma e C. chacoensis com base na morfologia da genitália masculina e feminina e na morfometria. Não há trabalhos semelhantes para as demais espécies e não existem chaves de identificação para o nível específico. O conhecimento a respeito da biologia do gênero é escasso, o que é surpreendente pelo fato de que ele faz parte dos diabroticinos, grupo tão estudado por sua importância econômica. 


\section{Objetivos}

São objetivos deste trabalho:

- Realizar análise cladística para testar o monofiletismo do gênero e estabelecer as relações entre as espécies, mediante estudo morfológico comparativo;

- Revisar taxonomicamente o gênero Cochabamba Bechyné, buscando novos caracteres morfológicos externos e internos para uma melhor delimitação e caracterização do gênero e de suas espécies;

- Estabelecer diagnoses atualizadas para as espécies;

- Atualizar as informações sobre a distribuição geográfica de cada espécie e confeccionar mapas de distribuição a partir dos dados compilados dos rótulos dos espécimes estudados e também da literatura. 


\section{Material e métodos}

\subsection{Material-examinado}

O material examinado, no total de 823 exemplares e algumas fotografias digitais, é proveniente das instituições listadas abaixo (ordenadas pelo acrônimo, segundo Arnett-Jr. et al. (1993), seguidas do nome completo da instituição, localização e curador responsável):

- BMNH (Natural History Museum), Londres, Inglaterra - Dra. Sharon Shute;

- DZUP (Departamento de Zoologia da Universidade Federal do Paraná), Curitiba, PR - Dra. Lúcia Massutti de Almeida;

- FIOC (Fundação Instituto Oswaldo Cruz), Rio de Janeiro, RJ - Dra. Jane Margaret Costa von Sydow;

- INBio (Instituto Nacional de Biodiversidad), Santo Domingo, Costa Rica - Dr. Angel Solís;

- IRSNB (Institut Royal des Sciences Naturelles de Belgique), Bruxelas, Bélgica - Dr. Limbourg, Dr. P. Grootaert;

- MCZC (Harvard University, Museum of Comparative Zoology), Cambridge, Estados Unidos - observação das fotografias dos holótipos de C. chacoensis e C. variolosa, disponíveis online no endereço <http://insects.oeb.harvard.edu/MCZ/index.htm>;

- MNHN (Museum National d'Histoire Naturelle), Paris, França - apesar de não existir material examinado proveniente dessa instituição, o acrônimo consta de alguns tipos;

- MNRJ (Museu Nacional da Universidade Federal do Rio de Janeiro), Rio de Janeiro, RJ - Dr. Miguel A. Monné;

- MPEG (Museu Paraense Emilio Goeldi), Belém, PA - Dr. Orlando Tobias;

- MZSP (Museu de Zoologia da Universidade de São Paulo), São Paulo, SP - Dra. Sônia Casari;

- NHMB (Naturhistorisches Museum Basel), Basiléia, Suíça - Dra. Eva Sprecher;

- NHRS (Naturhistoriska Riksmuseet), Estocolmo, Suécia - Dr. Bert Viklund;

- USNM (Smithsonian National Museum of Natural History), Washington, E. U. A. - Dr. Alexander S. Konstantinov, Dr. David G. Furth.

\subsubsection{Material-tipo}

Em 1967, Smith \& Lawrence publicaram uma revisão detalhada dos táxons publicados na seção Diabroticites até aquele momento, incluindo um catálogo dos tipos válidos, bem como as instituições nas quais estavam depositados. Juntamente com as descrições originais, esse trabalho constitui uma fonte confiável para avaliação dos tipos examinados. A seguir estão citadas as espécies, a categoria típica e a instituição depositária dos exemplares-tipo estudados, com alguns comentários. 
1. C. chacoensis - holótipo (MCZC) - foi possível apenas observar fotografias coloridas desse exemplar, disponíveis no sítio da instituição;

2. C. chrysopleura - tipo não examinado - segundo Smith \& Lawrence, não foi possível localizar nenhum exemplar-tipo desse táxon. Bechyné (1955b), entretanto, afirmou ter examinado tipos na coleção Oberthür, à época depositada no MNHN;

3. C. diversicolor - holótipo $(\mathrm{BMNH})$ - examinado em visita à instituição;

4. C. erythrodera - holótipo $(\mathrm{BMNH})$ - examinado em visita à instituição;

5. C. marginata - tipo não examinado - Smith \& Lawrence designaram um lectótipo para o táxon, que está depositado no MNHN;

6. C. mera - holótipo (NHMB) - examinado, por empréstimo;

7. C. polychroma - holótipo, alótipo (NHMB) - examinados, por empréstimo; parátipos (MZSP) - examinados;

8. C. rugulosa - tipo não examinado - foi examinado exemplar identificado como lectótipo na coleção do BMNH, que depois verificou-se não ser válido. Smith \& Lawrence citam etiquetas que não foram encontradas no espécime examinado e, além disso, a comparação com a descrição original, de Baly (1886), e material identificado por Bechyné, oriundo da coleção do NHMB, indicam que o exemplar observado em Londres não se trata de tipo e, tampouco, de representante do táxon em questão;

9. C. variolosa - holótipo (MCZC) - foi possível apenas observar fotografias coloridas desse exemplar, disponíveis no sítio da instituição;

10. C. volxemi - holótipo $(\mathrm{BMNH})$ - examinado em visita à instituição; parátipos (MZSP) - examinados.

\subsection{Estudo da morfologia}

O estudo da morfologia foi realizado principalmente com o auxílio de estereomicroscópio Zeiss e microscópio óptico Zeiss. As eletromicrografias de varredura foram obtidas apenas para a espécie-tipo do gênero, no Laboratório de Microscopia Eletrônica do Museu de Zoologia da Universidade de São Paulo.

\subsubsection{Dissecções}

As dissecções seguiram o protocolo descrito por Smith (1979), ligeiramente modificado, que revelou ser o método mais rápido e eficiente. O protocolo completo é descrito a seguir:

1. Aquecer o espécime alfinetado em água destilada por 2 ou 3 minutos, sem ferver (quanto maior o exemplar, maior o tempo de aquecimento);

2. Em água destilada fria, retirar o alfinete e remover o abdômen;

3. Remover a asa membranosa para estudo em estereomicroscópio;

4. Retirar as peças bucais e montá-las em lâmina provisória para observação em microscópio óptico (em glicerina ou álcool gel); 
5. Aquecer o abdômen em solução 1:10 de hidróxido de potássio e água destilada por 2 ou 3 minutos, sem ferver;

6. Em água destilada fria, rebater os tergitos, abrindo o abdômen pela margem lateral esquerda;

7. Repetir o passo 5 até que o abdômen esteja amolecido;

8. Em água destilada fria, separar a genitália do trato intestinal;

9. Enxaguar a genitália em uma mistura de 1:3 de ácido acético glacial e etanol (70\%);

10. Transferir a genitália para glicerina misturada com água destilada para estudo;

11. Montar edeago ou espermateca em lâmina provisória para observação em microscópio óptico (em glicerina ou álcool gel).

Uma solução detergente pode ser adicionada à água destilada no processo de aquecimento para limpar o espécime.

Após o estudo das partes dissecadas, as mesmas foram acondicionadas de maneira específica e mantidas junto ao exemplar de origem. Asas e escleritos abdominais amolecidos foram montados em cartões, enquanto peças bucais e estruturas da genitália interna foram acondicionadas em tubinhos plásticos com glicerina. Os exemplares sem a porção abdominal e/ou asas membranosas foram lavados em álcool antes de serem remontados, em alfinetes ou colados a triângulos entomológicos, dependendo da sua condição original.

\subsubsection{Ilustrações}

As ilustrações foram realizadas com auxílio de câmara clara acoplada ao estereomicroscópio e microscópio óptico. Os desenhos foram feitos a lápis e depois escaneados e transferidos para os programas Adobe Illustrator CS3 e Adobe Photoshop CS3, nos quais foi realizada a arte final, com auxílio de mesa digitalizadora Wacom Bamboo.

Para a obtenção das eletromicrografias, foi necessário que o material fosse totalmente desidratado (ponto crítico) e metalizado com uma camada de ouro. Os espécimes metalizados foram acondicionados em via seca, em vidros, com suas etiquetas.

Fotografias coloridas dos exemplares foram obtidas com câmera digital acoplada a estereomicroscópio Leica. As camadas foram, então, sobrepostas através do software de automontagem, Helicon Focus.

\subsubsection{Redescrições e diagnoses}

As redescrições foram baseadas no estudo morfológico do material estudado. Apresentam-se as redescrições do gênero e das espécies do grupo-interno, além da descrição de uma espécie nova. As redescrições incluem dados de catálogo, diagnose, lista de material examinado, dados de distribuição geográfica e discussão dos caracteres utilizados. 


\subsection{Análise Cladística}

A análise cladística foi implementada com base em 15 táxons terminais, com auxílio do programa TNT, versão 1.1 (Goloboff et al., 2008).

\subsubsection{Grupo-interno}

O grupo-interno foi composto pelas 10 espécies anteriormente incluídas em Cochabamba e uma espécie não identificada que revelou-se nova, indicada como $C$. n. sp.

\subsubsection{Grupo-externo}

Seguindo a classificação adotada por Seeno \& Wilcox (1982), Galerucinae está dividida em cinco tribos, das quais apenas três possuem registros para a biota neotropical, a saber: Galerucini, Metacyclini e Luperini. A subtribo Diabroticina inclui-se nesta última tribo e está dividida em quatro seções de gêneros (Diabroticites, Cerotomites, Phyllecthrites e Trachyscellidites).

Considerando a inexistência de informações filogenéticas para o gênero, a escolha do grupo-externo para análise cladística foi realizada a partir de análise preliminar utilizando espécies de gêneros representantes para parte da subfamília Galerucinae, preferencialmente de ocorrência neotropical. Iniciou-se a busca por espécies-tipo para os gêneros, mas, devido à escassez de material, foram selecionadas espécies com disponibilidade de exemplares na coleção do MZSP.

Assim, as quatro espécies selecionadas para a análise final foram: Coelomera cajennensis (Fabricius), espécie-tipo do gênero e da seção - Galerucini, Coelomerites; Cerotoma variegata (Fabricius) - Luperini, Diabroticina, Cerotomites; Diabrotica rufolimbata Baly - Luperini, Diabroticina, Diabroticites e Paranapiacaba teinturieri (Allard)- Luperini, Diabroticina, Diabroticites.

\subsubsection{Levantamento e codificação de caracteres}

Dada a ausência de informações sobre os estágios imaturos dos terminais incluídos na análise, apenas caracteres referentes à morfologia dos adultos foram analisados. A matriz de dados apresenta um total de 58 caracteres, sendo 45 referentes à morfologia externa geral (dos quais 5 são relacionados à coloração) e 13 à genitália.

Os caracteres foram selecionados seguindo critérios de facilidade de visualização, variabilidade nos grupos examinados e citação nas descrições originais. Esse último critério foi incluído de forma a testar a validade de alguns dos caracteres citados por autores anteriores em diagnoses em diversos níveis taxonômicos. A codificação dos caracteres seguiu o método de padronização sugerido por Sereno (2007). A contingência 
de caracteres, quando houver, está indicada na Lista de Caracteres (p. 17). A matriz de dados (Tab. 1) foi confeccionada com auxílio do programa Mesquite, versão 2.73. (Maddison \& Maddison, 2010).

\subsubsection{Algoritmos}

Pelo tamanho reduzido do conjunto de dados (58 caracteres versus 15 táxons terminais e 16 estados), foi possível utilizar o algoritmo branch-and-bound de busca exaustiva (opção "Implicit Enumeration" do menu "Analyze"). Posteriormente à busca com pesos iguais, uma nova análise foi realizada, utilizando o algoritmo de pesagem sucessiva de Farris (1969), implementado no TNT a partir do script "REWT.run", rodado a partir do índice de consistência (IC) obtido para as árvores mais parcimoniosas encontradas na busca exaustiva.

Como não há evidências ou hipóteses prévias para a transformação dos estados observados, todos os caracteres foram tratados como não-ordenados.

O enraizamento foi realizado a posteriori (Nixon \& Carpenter, 1993), no grupo-externo de relacionamento hierárquico mais distante (Coelomera cajennensis). Árvores de consenso foram obtidas em cada análise, a partir do comando "Nelsen" (menu "Trees", opção "Consensus").

A discussão das topologias seguiu a proposta de Amorim (1982)de classificação por sequenciação, na qual um clado em uma dada árvore é denominado "grupo", seguido do nome do terminal precoce e o símbolo "+".

\subsubsection{Visualização das árvores e otimização dos caracteres}

Tanto a visualização das árvores, como a otimização dos caracteres foram implementadas com auxílio do programa WinClada, versão 0.9.9 (Nixon, 1999). Os caracteres ambíguos estão indicados na Lista de Caracteres, juntamente com o algoritmo de otimização utilizado (ACCTRAN ou DELTRAN), quando for o caso.

\subsection{Terminologia - definições e comentários}

A terminologia adotada segue, em grande parte, Lingafelter \& Konstantinov (1999) - morfologia externa, peças bucais e genitália feminina; e Moura (2009) genitália masculina. Devido a certas particularidades observadas na morfologia de Chrysomelidae/Galerucinae e para esclarecer alguns conceitos, utilizados, por vezes, de maneira obscura na literatura, alguns termos foram selecionados e discutidos. O termo adotado aqui é o primeiro de cada parágrafo, em negrito. Entre parênteses, após o termo, está indicada a referência na qual é encontrado (e, às vezes, definido) e entre colchetes estão citados os termos considerados sinônimos (em tradução livre, feita pela autora, para o português, se não houver referência na literatura em língua portuguesa), quando houver. 
Muitas das definições foram inferidas a partir de ilustrações ou utilizações gerais, sem autor específico, e por isso aparecem sem referência (sendo assim a definição é dada pela autora a partir da interpretação da literatura). Aquelas que foram definidas claramente em algum estudo são referenciadas.

\subsubsection{Morfologia externa}

Os taxonomistas especialistas em Chrysomelidae normalmente fazem uso, no que se refere à morfologia externa, da terminologia considerada clássica para os insetos, encontrada, por exemplo, em Snodgrass (1935). Na obra clássica de Crowson (1981), diversos termos introduzidos por Snodgrass foram discutidos e adaptados, de forma a incorporar as peculiaridades dos coleópteros, descritas nos trabalhos disponíveis à época. Diagramas esquemáticos são apresentados nas Figs. 5 e 6.

Calos antenais (Lingafelter \& Konstantinov, 1999)[= calos supra-antenais (Bechyné \& Bechyné, 1961), tubérculos frontais (Wilcox, 1965), processos frontais (Cabrera, 1999), tubérculos anteníferos (Moura, 1998)]: duas áreas elevadas da parede cranial, localizadas na porção inferior do vértice, em posição dorsal em relação às inserções antenais (Lingafelter \& Konstantinov, 1999).

Calo do hipômero: região elevada, geralmente ovóide, que ocupa grande parte da porção apical do hipômero - Fig. 15c.

Carena inter-antenal (Wilcox, 1965): região elevada da fronte, entre as inserções antenais, que continua até a porção fronto-clipeal, com aspecto de "T" invertido.

Esporão tibial (Crowson, 1981): esporão localizado no ápice da tíbia, na margem interna - Fig. 16h.

Estrias elitrais (Spilman, 1971): linhas longitudinais que se estendem desde a base até o ápice do élitro, presentes em toda a sua área, frequentemente sulcadas (originárias de sulcos do tegumento elitral) ou pontuadas (formadas por pontos em depressões do tegumento elitral) (Spilman, 1971) - Fig. 14a.

Plicas umerais (Krysan \& Smith, 1987): depressões longitudinais do tegumento elitral, que se iniciam na base da porção umeral, terminando geralmente antes do terço apical do élitro - Fig. 14f. Diferentemente das estrias elitrais, as plicas umerais não são bem definidas, ocorrendo em menor número.

Pontuação elitral reticulada (Bechyné, 1955b): padrão de organização da pontuação elitral, no qual os pontos, em geral, são considerados grossos, isto é, de diâmetro e profundidade relativamente grandes, e sua disposição é considerada irregular (citada como "confusa" por autores antigos, como Chevrolat), de forma que o 
tegumento apresenta inúmeras saliências, formando células (os pontos) delimitadas por nervuras (tegumento) entrecruzadas, tal como redes ou rendas - Fig. 12b. Essa expressão provavelmente foi retirada da Botânica, área em que é utilizada para descrever o padrão de nervação de certas folhas.

Porção adesiva do tarsômero (Cabrera et al., 2008) [= pulvilo tarsal (Wilcox, 1965)]: região de formato ovóide, que pode ocupar a parcial ou totalmente a superfície ventral do tarsômero basal, nos machos, onde estão localizadas cerdas de ápice dilatado, em forma de espátula - Fig. 16e.

Sutura fronto-clipeal (Lingafelter \& Konstantinov, 1999) [= sutura epicranial (Snodgrass, 1935), sulco ântero-frontal (Cabrera et al., 2008)]: linha transversal que demarca o limite entre a fronte e o clípeo - Fig. 6a.

Ventrito V (Crowson, 1981)[= esternito VII (Snodgrass, 1935), urosternito V (Moura, 1998)]: último esternito abdominal visível (Crowson, 1981).

\subsubsection{Genitália masculina}

Em relação à genitália masculina, há certa variação na terminologia utilizada nos trabalhos relacionados a Chrysomelidae, provavelmente resultado da grande variabilidade de formas encontradas nesse grupo, o que dificulta a inferência da homologia das partes. Em artigo recente, Moura (2009) resumiu a terminologia mais utilizada em Galerucinae, citando algumas definições, baseadas principalmente nas obras de Sharp \& Muir (1912), Powel (1941), Lindorth \& Palmen (1956) e Wilcox (1965).

Aba apical (Powel, 1941): aba laminar, presente no ápice da placa dorsal do lobo-médio, que está presente em alguns grupos de Galerucinae e aparentemente tem como função proteger o óstio (Moura, 2009) - Fig. 5c.

Edeago (Sharp \& Muir, 1912): conjunto formado pelo lobo-médio e tégmen, que são ligados entre si através da membrana conectiva (Sharp \& Muir, 1912).

Escleritos do saco interno (Lindorth \& Palmen, 1956): presentes no saco interno de muitas espécies de Galerucinae, os escleritos podem ter forma de espinhos, dentículos, papilas, placas laminares e outras estruturas complexas, as quais auxiliam a fixação do saco interno na genitália feminina durante a cópula. Na subfamília Galerucinae o número de escleritos varia, ao que se sabe, de nenhum a cinco escleritos bem definidos (Flowers \& Eberhard, 2006) - Figs. 17c, f, i, l, o.

Ganchos basais (Wilcox, 1965): extremidade da região basal do lobo-médio, com projeções em forma de ganchos, que delimitam o orifício basal. Acredita-se que os ganchos basais evitem que o lobo-médio seja totalmente extrovertido durante a 
cópula, uma vez que suas extremidades prendem-se ao redor da borda posterior do último segmento abdominal (Verma, 1969) - Fig. 17q.

Lobo-médio (Sharp \& Muir, 1912) [=pênis (Crowson, 1981)]: porção central do edeago, presumidamente a estrutura esclerotizada que é introduzida na genitália feminina durante a cópula. Em Chrysomelidae, o lobo-médio é uma peça tubular, de forma variada e aspecto curvado (Powel, 1941) - Fig. 17c.

Orifício apical (Powel, 1941) [= orifício médio (Sharp \& Muir, 1912), óstio (Moura, 2009)]: abertura no ápice do lobo-médio através da qual o saco interno é extrovertido durante a cópula (Moura, 2009).

Orifício basal (Powel, 1941): abertura na base do lobo-médio, através do qual passa o ducto ejaculatório mediano (Moura, 2009).

Saco interno (Sharp \& Muir, 1912) [= ectophallus+endophallus (Snodgrass, 1935), $=$ endophallus (Flowers \& Eberhard 2006)]: porção membranosa interna do edeago, quando em repouso, que é evertida no momento da cópula, com função importante na transferência de esperma para a fêmea (Mann \& Crowson, 1996). Segundo Snodgrass (1935), o saco interno seria o resultado da retração da parede externa do lobo-médio. Como Verma (1969) observou para algumas espécies do gênero Galerucella, nem sempre é possível distinguir a porção do saco interno nos Galerucinae que se everte no momento da cópula (definida como ectophallus) daquela que seria, como definiu Snodgrass (1935) originária da "fusão das faces côncavas mesais dos tubos fálicos primários", o endophallus verdadeiro. Por esse motivo, seguindo Verma (1969), o nome saco interno é utilizado para caracterizar todas as partes membranosas internas no lobo-médio.

Spiculum gastrale (Sharp \& Muir, 1912)[= segundo espículo (Verma, 1996)]: nos galerucíneos, é uma estrutura hastiforme esclerotizada em forma de "U", "V" ou "Y", de tamanho variável, conectada por membranas ao ventrito $\mathrm{V}$ e que em geral envolve o edeago ventralmente (Moura, 2009) - Fig. 5c.

Tégmen (Sharp \& Muir, 1912) [= spiculum (Verma, 1969), membrana + ganchos basais + spiculum (LeSage, 1986)]: estrutura que está conectada ao lobo médio e ao segmento abdominal apical através de duas membranas conectivas. De maneira geral, os membros de Galerucinae formam um grupo com tégmen reduzido, de estrutura bifurcada e disposta ventralmente ao lobo-médio (Wilcox, 1965; Verma, 1969). Entretanto, Verma (1969), relembrando Muir (1918), chegou à conclusão de que essa estrutura não pode ser comparada consistentemente entre os crisomelídeos, já que ela parece ter se originado diversas vezes e de maneiras diferentes na família - Fig. 5c. 


\subsubsection{Genitália feminina}

Apenas há pouco mais de três décadas é que se passou a dar importância à genitália feminina em Coleoptera como fonte de caracteres para diagnosticar táxons em diversos níveis e entender o seu relacionamento filogenético (Konstantinov, 2002). Em Chrysomelidae, há grande dificuldade em estabelecer homologias para as estruturas que formam o complexo genital feminino, devido à grande especialização de alguns grupos. Os termos citados aqui foram reunidos em Konstantinov (1998) e Leschen et al. (2010).

Bursa copulatrix (Snodgrass, 1935) [= vagina (Konstantinov, 1998), vagina + bursa (Cabrera \& Walsh, 2004), bursa vaginal (Leschen et al., 2010)] : parte expandida da câmara genital, em forma de saco, onde há a inserção do oviduto comum e do ducto da espermateca (Leschen et al., 2010) - Fig. 5b.

Palpos vaginais (Mickoleit, 1973) $[=$ ovipositor (Crowson \& Crowson, 1996), gonocoxitos (Duckett, 1995), hemiesternitos (Reid, 1988), coxitos (Cabrera, 1999)]: presentes tipicamente nos galerucíneos, são estruturas pareadas, alongadas, frequentemente com cerdas, localizadas no interior da câmara genital. Não há hipótese conclusiva para a origem evolutiva dessas estruturas, que provavelmente têm função sensorial durante a cópula e talvez atuem na seleção sexual críptica (Konstantinov, 1998) - Figs 5b.

Spiculum ventrale (Leschen et al., 2010) [= spiculum gastrale (Verma, 1969), tignum (Konstantinov, 1998)]: projeção alongada, esclerotizada do esternito VIII membranoso, que fica voltada ventralmente no abdômen (Leschen et al., 2010) Fig. 5b.

Vulva (Snodgrass, 1935) [= vagina (Cabrera, 1999)]: abertura que comunica a câmara genital com o exterior do corpo.

\subsection{Distribuição geográfica}

Os dados utilizados para atualização da informação referente à distribuição geográfica das espécies foram compilados a partir das etiquetas de cada exemplar e também retirados da literatura. Tais dados estão disponíveis em banco de dados eletrônico elaborado a partir do software Microsoft Access. A transcrição das etiquetas está disponível na lista de material examinado de cada espécie. As informações foram ordenadas, quando possível, pela orientação da localidade (país, estado/departamento) de origem (de Norte a Sul, de Oeste a Leste) e, secundariamente, em ordem alfabética.

Os mapas (Figs. 23 e 24) foram confeccionados com auxílio do software Quantum GIS, a partir de coordenadas geográficas obtidas nos bancos de dados eletrônicos Getty Thesaurus of Geografic Names, Global Gazetteer e SpeciesLink. 


\section{Resultados e discussão}

\subsection{Análise cladística}

\subsubsection{Topologias}

A busca exaustiva com pesos iguais encontrou 13 árvores mais parcimoniosas de comprimento igual a 102 passos $(\mathrm{IC}=75 ; \mathrm{IR}=62)$, que geraram uma árvore de consenso (Fig. 1) de comprimento igual a $108(\mathrm{IC}=71 ; \mathrm{IR}=53)$. Em razão da politomia encontrada no cladograma de consenso, tanto no grupo interno, quanto no grupo externo, nova análise foi efetuada com o algoritmo de pesagem sucessiva de caracteres.

Com a pesagem sucessiva dos caracteres, a busca exaustiva encontrou 3 árvores (Fig. 2) mais parcimoniosas de comprimento igual a 102 passos $(\mathrm{IC}=75 ; \mathrm{IR}=62)$, cujo consenso (Fig. 3) tem comprimento igual a 103 passos $(\mathrm{IC}=74 ; \mathrm{IR}=60)$. O consenso obtido nessa busca apresenta uma resolução maior das relações, tendo sido, portanto, utilizado para a discussão filogenética.

Considerando comparações com análises prévias, o conjunto de dados foi novamente analisado, com pesos iguais, excluindo-se um dos grupos-externos, Paranapiacaba teinturieri, para verificar a sua influência na topologia das árvores encontradas. Essa re-análise encontrou 1 árvore (Fig. 4) mais parcimoniosa de comprimento igual a 95 passos $(\mathrm{IC}=80 ; \mathrm{IR}=64)$.

\subsubsection{Lista de caracteres}

0. Vértice, sutura mesocranial:

(0) completa (estendendo-se desde o vértice até a crista frontal, bem demarcada) Fig. 8f ;

(1) incompleta (pouco demarcada, sendo restrita à porção central da fronte, entre os calos antenais) - Fig. 6a.

Segundo Lingafelter \& Konstantinov (1999), a maioria dos Galerucinae possui a sutura mesocranial desenvolvida, completa ou incompleta. O estado considerado plesiomórfico na presente análise é encontrado apenas na raiz ( C. cajennensis).

1. Olhos, tamanho relativo à largura da cabeça em vista dorsal:

(0) pequenos (ocupam a metade ou menos da largura total da cabeça em em vista dorsal) - Fig. 6c;

(1) grandes (ocupam ca. 2/3 ou mais da largura total da cabeça em em vista dorsal)

- Fig. 6b.

2. Linha orbital, grau de impressão no tegumento: 
(0) pouco impressa, quase inconspícua - Fig. 8f;

(1) bem demarcada - Fig. 7a.

3. Linha orbital, posição relativa ao olho:

(0) próxima - Fig. 6d;

(1) distante - Fig. 7a.

O algoritmo utilizado na otimização desse caráter na árvore escolhida para a discussão foi o ACCTRAN, já que a reversão do estado plesiomórfico (0) é uma hipótese mais simples para explicar a transformação.

4. Sulco inter-ocular, grau de impressão:

(0) completo, bem demarcado - Fig. 8f;

(1) incompleto, limitado à porção mediana da linha acima dos calos antenais - Fig. 7a.

5. Sulco inter-ocular, posição da porção central em vista lateral :

(0) na mesma linha do vértice - Fig. 8f;

(1) defletido - Fig. 7a.

6. Inserções antenais, posição na fronte em relação à linha mediana dos olhos:

(0) basal (próxima da margem fronto-clipeal) - Fig. 8f;

(1) na mesma linha - Fig. 7a.

Esse caráter foi utilizado por Laboissière para diferenciar as tribos Galerucini e Luperini (Crowson \& Crowson, 1996).

7. Antenas, antenômero III do macho, margem lateral:

(0) lisa, sem projeções - Fig. 9a;

(1) com projeção pontiaguda - Fig. 9c.

8. Antenas, antenômero III, comprimento em relação ao comprimento do antenômero $\mathrm{V}$ :

(0) maior - Fig. 9a;

(1) menor - Fig. 9d;

(2) igual - Fig. 9f.

A escolha do antenômero V para comparação deve-se ao fato de que este antenômero, assim como os seguintes, aparentemente não apresenta variação na tribo Luperini. Esse caráter foi otimizado na topologia discutida com uso do algoritmo DELTRAN, 
já que não foi possível definir uma hipótese para a série de transformação e a transição de um estado para outro qualquer pode ser interpretada como plausível, dada a variabilidade da configuração desse antenômero na tribo.

9. Antenas, antenômero IV do macho, margem lateral:

(0) lisa, sem projeções - Fig. 9a;

(1) com projeção pontiaguda - Fig. 9c.

10. Labro, número de cerdas medianas:

(0) dezesseis - Fig. 8f;

(1) oito;

(2) seis - Fig. 7a.

Segundo Lingafelter \& Konstantinov (1999), a maioria dos Galerucinae tem mais que oito cerdas longas, embora alguns tenham apenas seis. É interessante notar o padrão do número de cerdas encontrados nos terminais utilizados na presente análise, isto é, não foi encontrado nenhum estado intermediário entre dezesseis e oito cerdas. ACCTRAN foi o algoritmo escolhido para otimizar o caráter na topologia discutida, uma vez que a perda de cerdas é uma hipótese que explicaria a transformação com menor número de pressupostos.

11. Pronoto, relação entre comprimento e largura:

(0) mais largo que longo - Fig. 11e;

(1) aproximadamente tão longo quanto largo - Fig. 10a.

Esse caráter, que descreve as proporções do pronoto, é utilizado em estudos filogenéticos de Chrysomelidae com diversos graus de abrangência, como por exemplo para descrever as relações entre as subfamílias (Crowson \& Crowson, 1996), entre os gêneros da tribo Galerucini (Swigonová \& Kjer, 2004) e entre os gêneros de algumas seções de Luperini (Wagner \& Kurtscheid, 2005; Stapel et al., 2008). No presente trabalho, o caráter foi significativo, representando uma sinapomorfia para o clado que representa o gênero Cochabamba.

12. Pronoto, superfície:

(0) com um par de depressões medianas - Fig. 10b;

(1) lisa, sem depressões.

13. Pronoto, superfície, localização das depressões medianas:

(0) laterais ao disco - Fig. 11f;

(1) disco - Fig. 10b; 
(2) metade basal - Fig. 10e;

(3) terço basal - Fig. 11a.

Caráter contingente ao caráter 12 .

14. Pronoto, profundidade das depressões medianas:

(0) profunda - Fig. 11f;

(1) moderadamente profunda - Fig. 10a.

(2) rasa - Fig. 10b.

Caráter contingente ao caráter 12. Na árvore discutida o caráter foi otimizado com o algoritmo DELTRAN, porque o paralelismo é uma hipótese mais simples para explicar a transformação.

15. Pronoto, formato das depressões medianas:

(0) subtriangular - Fig. 11f;

(1) circular - Fig. 11a;

(2) semicircular - Fig. 10b;

(3) ovóide - Fig. 11d.

16. Pronoto, espessura dos pontos do disco:

(0) fina - Fig. 10a;

(1) grossa - Fig. 11e.

17. Pronoto, espessura dos pontos das margens:

(0) fina - Fig. 10a;

(1) grossa - Fig. 11e.

18. Pronoto, densidade da pilosidade:

(0) densa;

(1) esparsa.

19. Pronoto, posição das porções laterais da margem posterior em relação ao eixo ântero-posterior:

(0) moderadamente inclinadas;

(1) fortemente inclinadas.

Esse caráter já foi utilizado para diagnosticar o gênero Cochabamba (Bechyné, 1955b), mas, no presente trabalho, representa uma sinapomorfia para a tribo Luperini. 
20. Protórax, calo do hipômero:

(0) ausente (superfície ventral do hipômero contínua, lisa);

(1) presente - Fig. 15c .

21. Escutelo, largura da margem posterior em relação à margem anterior:

(0) ligeiramente menor;

(1) cerca de $1 / 4$ da largura.

22. Élitros, densidade da pilosidade da superfície dorsal:

(0) densa;

(1) esparsa.

23. Élitros, estrias:

(0) ausentes - Fig. 14b;

(1) presentes - Fig. 14a.

24. Élitros, densidade da pontuação:

(0) densa - Fig. 13d;

(1) moderadamente densa - Fig. 12a.

25. Élitros, tegumento entre os pontos:

(0) liso - Fig. 12c;

(1) reticulado - Fig. $12 \mathrm{~b}$.

26. Élitros, espessura dos pontos:

(0) fina - Fig. 12d;

(1) moderada - Fig. 12e.

27. Élitros, plicas umerais:

(0) ausentes (superfície contínua) - Fig. 14b;

(1) presentes - Fig. 14f.

Caráter utilizado para diferenciar algumas espécies de Diabrotica do grupo virgifera (Krysan \& Smith, 1987).

28. Élitros, número de plicas umerais:

(0) duas - Fig. 14c;

(1) cinco - Fig. 14f.

Caráter contingente ao caráter 27. 
29. Élitros, epipleuras:

(0) ligeiramente inclinadas;

(1) fortemente inclinadas (formando um ângulo quase reto com a porção elitral adjacente);

(2) moderadamente inclinadas.

Bechyné (1955b)utilizou esse caráter para diferenciar Cochabamba dos demais diabroticinos, o que não é corroborado no presente trabalho. Dada a impossibilidade de determinar, no presente estudo, a série de transformação do caráter, sua otimização na árvore discutida foi realizada com o algoritmo DELTRAN.

30. Mesepisterno, densidade da pilosidade:

(0) moderadamente densa;

(1) muito densa (encobrindo completamente a escultura do esclerito) - Fig. 15g.

31. Mesepímero, densidade da pilosidade:

(0) moderadamente densa;

(1) muito densa (encobrindo completamente a escultura do esclerito) - Fig. 15g.

32. Metepisterno, densidade da pilosidade:

(0) moderadamente densa;

(1) muito densa (encobrindo completamente a escultura do esclerito) - Fig. 15g.

Caráter utilizado para diferenciar Cochabamba dos outros diabroticinos (Bechyné, 1955b), não corroborado na presente hipótese. A otimização do caráter na topologia discutida foi realizada com o algoritmo DELTRAN, porque pressupõe-se que a variação quantitativa das cerdas nessa região do corpo pode ser resultado de paralelismo.

33. Metasterno, densidade da pilosidade lateral:

(0) moderadamente densa;

(1) muito densa (encobrindo completamente a escultura do esclerito).

O algoritmo DELTRAN foi utilizado para otimizar esse cárater na árvore, pelo mesmo motivo exposto para o caráter 32 .

34. Perna protorácica, esporão tibial da fêmea:

(0) ausente;

(1) presente - Figs. 16h. 
35. Perna metatorácica, esporão tibial do macho tíbia:

(0) ausente;

(1) presente.

36. Perna protorácica, cerdas ventrais no tarsômero I do macho:

(0) retas, iguais às demais cerdas das pernas em todo o tarsômero;

(1) com ápice expandido, em região ovóide (disco adesivo) - Figs. 16e, f.

37. Perna mesotorácica, cerdas ventrais no tarsômero I, macho:

(0) retas, iguais às demais cerdas das pernas em todo o tarsômero;

(1) de ápice expandido, em região ovóide (disco adesivo).

38. Ventrito V (macho), margem posterior:

(0) com emarginação semi-circular mediana - Fig. 16a;

(1) truncada .

39. Tergito VIII:

(0) encoberto pelos élitros;

(1) exposto.

40. Edeago, forma do tégmen:

(0) hastiforme;

(1) de "V".

41. Edeago, grau de curvatura da porção mediana do lobo-médio em vista lateral:

(0) moderadamente recurvada - Fig. 17q;

(1) recurvada - Fig. 17b.

42. Edeago, largura da porção mediana do lobo-médio em relação à porção apical:

(0) semelhante - Fig. 17q;

(1) menor - Fig. 17b.

43. Edeago, spiculum gastrale:

(0) ausente;

(1) presente.

44. Edeago, escleritos do saco interno do lobo-médio:

(0) ausentes;

(1) presentes. 
45. Edeago, escleritos do saco interno do lobo-médio:

(0) dois;

(1) três - Fig. 17o;

(2) quatro - Fig. 17f;

(3) cinco - Fig. 17c.

Caráter contingente ao caráter 44.

46. Edeago, ganchos basais:

(0) presentes;

(1) ausentes.

47. Edeago, aba apical:

(0) ausente - Fig. 17p;

(1) presente - Fig. 17a.

48. Bursa copulatrix, porção central:

(0) membranosa;

(1) esclerotizada - Fig. 18a.

49. Bursa copulatrix, tipo de esclerotização da porção central:

(0) formando um anel - Fig. 18a;

(1) formando uma placa ventral - Fig. 18c;

(2) formando uma placa dorsal cujas extremidades são recurvadas - Fig. 18f.

50. Palpos vaginais:

(0) curtos - Fig. 19h;

(1) alongados - Fig. 19a.

51. Spiculum ventrale, comprimento:

(0) curto (de comprimento menor do que o comprimento do esternito);

(1) longo (de comprimento cerca de duas vezes maior do que o comprimento do esternito).

52. Spiculum ventrale:

(0) pouco esclerotizado;

(1) fortemente esclerotizado. 
53. Élitros, iridescência (brilho metálico):

(0) ausente - Fig. 12a;

(1) presente - Figs. 13f, g.

O caráter que descreve a presença de brilho elitral metálico foi considerado um caráter à parte no grupo dos caracteres relacionados à coloração, uma vez que estudos indicam que essa característica presente em certos coleópteros deve-se a um mecanismo físico diferente daquele que resulta nos padrões de pigmentação do tegumento (Kinoshita et al., 2008; Seago et al., 2009).

54. Élitros, coloração predominante da porção umeral:

(0) negra - Fig. 12a;

(1) amarela - Fig. 13e;

(2) esverdeada - Fig. 12d;

(3) vermelha - Fig. 12 b.

55. Élitros, coloração predominante da metade apical:

(0) negra - Fig. 12a;

(1) amarela - Fig. 13e;

(2) esverdeada - Fig. 12d;

(3) vermelha - Fig. 12b.

56. Élitros, coloração das margens laterais:

(0) negra - Fig. 12a;

(1) amarela - Fig. 12e;

(2) esverdeada - Fig. 12d;

(3) vermelha - Fig. 12b.

57. Pronoto, coloração:

(0) castanha - Fig. 13d;

(1) amarelada - Fig. 13e;

(2) esverdeada - Fig. 12e;

(3) negra - Fig. 12a. 


\subsubsection{Monofilia de Cochabamba}

As topologias encontradas na análise cladística indicam que a monofilia do gênero Cochabamba deverá ser recuperada com a exclusão da espécie $C$. volxemi e a inclusão de Diabrotica rufolimbata. O terminal C. volxemi aparece como sendo mais proximamente relacionado ao grupo-externo Paranapiacaba teinturieri, o que é suportado pelas seguintes sinapomorfias: antenômero III tão longo quanto o antenômero V, 8(2); pontuação das margens do pronoto formada por pontos grossos, 17(1); bursa copulatrix com porção mediana esclerotizada, formando uma placa ventral, 49(1) e élitros iridescentes, 53(1).

O clado que representa o gênero, como grupo monofilético, é sustentado por 4 sinapomorfias: olhos grandes, 1(1); antenômero III mais curto do que o antenômero V, 8(1); pronoto aproximadamente tão largo quanto longo, 11(1) e saco interno do lobo-médio com quatro escleritos, 45(2). De tais sinapomorfias, apenas uma das características é citada como peculiar para o gênero Cochabamba (Cabrera, 1999)-caráter 8. A pilosidade muito densa do metepisterno, 32(1), descrita como Bechyné como diagnóstico para o gênero, é representada na topologia como um paralelismo entre a espécie $C$. volxemi e o grupo dos demais Cochabamba, sofrendo reversão em um clado mais interno, formado por D. rufolimbata e C. mera, 32(0). É interessante notar que as sinapomorfias aqui encontradas são, também, características atribuídas aos táxons do gênero Diabrotica (Krysan \& Smith, 1987; Wilcox, 1965), fato que pode explicar, em parte, a posição do terminal D. rufolimbata no interior do clado formado pelo grupo-interno. Outras características que definem esse clado, homoplásticas, são a linha orbital próxima ao olho, $3(0)$, e a pilosidade muito densa do metasterno, que encobre o esclerito completamente, $33(1)$.

\subsubsection{Agrupamentos internos}

Mais internamente existem outros agrupamentos a discutir. Três das espécies do grupo-interno, C. polychroma, C. chacoensis e C. rugulosa apresentam posição indefinida. C. polychroma é definido pelas seguintes características: depressões medianas na metade basal do disco do pronoto, 13(2); depressões medianas do pronoto de profundidade rasa 14(2); mesepímero completamente encoberto por pilosidade muito densa 31(1) e pronoto esverdeado $57(2)$ - sendo os três últimos homoplásticos. O terminal $C$. chacoensis é definido por duas autapomorfias, representadas pelos caracteres 23(1) e 45(3), respectivamente: presença de estrias elitrais e cinco escleritos no saco interno do lobo-médio. Já C. rugulosa define-se por quatro homoplasias: presença de plicas elitrais umerais, 27(1); mesepisterno e mesepímero completamente encobertos por pilosidade muito densa, 30(1) e 31(1), respectivamente, e porção apical do élitro predominantemente esverdeada, $55(2)$.

Dois agrupamentos internos são observados na topologia: o grupo $C$. chrysopleura $+C$. 
diversicolor e C. n. sp.+. O grupo C. chrysopleura $+C$. diversicolor é suportado por três sinapomorfias, 54(3), 55(3) e 56(3), as quais correspondem à coloração avermelhada do élitro. Enquanto o terminal C. chrysopleura é definido por uma autapomorfia, depressões medianas do pronoto de formato semicircular, 15(2) e pelos caracteres homoplásticos, depressões medianas do pronoto de profunidade rasa, 14(2) e tegumento elitral reticulado, 25(1), C. diversicolor apresenta apenas uma homoplasia como suporte, representada pelo caráter 27(1): presença de plicas umerais.

O grupo C.n. sp.+ define-se por uma autapomorfia, presença de cinco plicas umerais, 28(1) e duas características homoplásticas, relacionadas à coloração elitral esverdeada de margens laterais amareladas (caracteres 55(2) e 56(1), respectivamente). O terminal C. n. sp. é caracterizado pelo formato ovóide das depressões medianas, 15(3), de profundidade rasa, 14(2) e presença de plicas umerais, 27(1) - sendo os dois últimos homoplásticos.

Os caracteres 54(2), porção umeral do élitro de coloração esverdeada, e 57(2), coloração do pronoto esverdeada, definem o grupo C. maginata+, sendo o segundo homoplástico. Mais internamente a esse clado, formam-se agrupamentos suportados apenas por homoplasias, o clado C. marginata $+C$. variolosa, definido pelo caráter 25(1), tegumento elitral reticulado, e o clado $C$. erythrodera + , definido pelo caráter 26(0), pontuação elitral formada por pontos finos - reversão. O terminal C. marginata é caracterizado pelas seguintes homoplasias: depressões medianas do pronoto de profundidade rasa, 14(2) e formato subtriangular, 15(0). Já o terminal C. variolosa é suportado por apenas uma homoplasia, representada pelo caráter 56(2), margens laterais do élitro de coloração esverdeada. O terminal C. erythrodera define-se por três autapomorfias, representadas pelos caracteres 13(2), depressões medianas do pronoto localizadas na metade basal; 40(1), tégmen em "V e 49(2), bursa copulatrix com porção central esclerotizada formando uma placa dorsal com extremidades recurvadas; além da homoplasia representada pelo caráter 57(0), pronoto de coloração castanha - reversão.

Finalmente, o clado formado por D. rufolimbata $+C$. mera é definido por duas reversões, representadas pela pilosidade moderadamente densa do metepisterno e metasterno, 32(0) e 33(0), respectivamente. Enquanto o terminal D. rufolimbata é suportado por uma autapomorfia, 12(1), superfície do pronoto lisa, sem depressões, o terminal C. mera é caracterizado por duas homoplasias, presença de plicas umerais, 27(1) e margens elitrais laterais de coloração esverdeadas, 56(2).

Nota-se, portanto, que a resolução do relacionamento inter-específico, quando houve, foi determinada a partir de caracteres referentes à presença de plicas elitrais umerais e à coloração. Apesar da dificuldade no estabelecimento de homologias para os padrões de coloração, visto que o mecanismo de determinação da cor nos crisomelídeos não foi adequadamente estudado, caracteres desse tipo, que normalmente são úteis para auxiliar a identificação em nível específico, tem sido considerados importantes na reconstrução da filogenia de alguns grupos (Areekul \& Quicke, 2006). No caso de Cochabamba, esse caráter 
mostrou-se significativo para compreender a diversificação dos ramos em nível específico, além de, muitas vezes, auxiliar a definição dos terminais.

A posição dos terminais D. rufolimbata e C. mera é alterada de maneira significativa quando excluiu-se da análise o grupo-externo P. teinturieri. Isso pode ser explicado, em parte, pelas sinapomorfias que definem o gênero Cochabamba nessa análise: pilosidade muito densa no metepisterno e no metasterno (caracteres 32 e 33, respectivamente). Esses caracteres são interpretados, na análise que incluiu P. teinturieri, como reversões (homoplasias) para o clado (D. rufolimbata + C. mera). Outro fato que esclarece o comportamento desses terminais nas diferentes topologias é o de que $P$. teinturieri apresenta um número maior de diferenças morfológicas se comparado ao grupo-interno (excluindo-se, é claro, C. volxemi), do que o terminal D. rufolimbata. Por essa razão, provavelmente a inclusão de outros grupos-externos na análise, que amostrem a variabilidade encontrada nos gêneros Diabrotica e Paranapiacaba altere novamente o relacionamento entre os terminais já incluídos.

\subsubsection{Grupo-irmão}

O cladograma indica um relacionamento próximo, como esperado, de P. teinturieri com as espécies de Cochabamba, com diversas sinapomorfias suportando o clado que representa a seção Diabroticites. No entanto, devido à ausência de hipóteses filogenéticas para os gêneros da tribo Luperini, somada ao grande número de táxons incluídos nessa tribo, não é possível determinar a posição exata do gênero Cochabamba e sua relação com os demais gêneros da seção. 


\subsection{Taxonomia}

\subsubsection{Considerações taxonômicas}

A hipótese filogenética proposta no presente trabalho (Fig. 3) indica que o gênero Cochabamba é merofilético e uma das condições para que a sua monofilia seja estabelecida é a exclusão da espécie C. volxemi, que foi recuperada como grupo-irmão de Paranapiacaba teinturieri. Além das sinapomorfias encontradas para esse agrupamento, há grande semelhança morfológica entre essas duas espécies, as quais são notadas principalmente no formato do pronoto e da cabeça, na configuração dos antenômeros e, particularmente, na similaridade entre as estruturas internas da genitália feminina. A inclusão da espécie-tipo do gênero Paranapiacaba, P. decemverrucata (Gahan), na análise cladística não foi possível devido à escassez de exemplares para dissecção. No entanto, as semelhanças morfológicas externas já mencionadas também são encontradas na comparação de C. volxemi com $P$. decemverrucata (Gahan). Com base nesse conjunto de evidências, C. volxemi é re-alocada no gênero Paranapiacaba, sendo redescrita em separado (página 55).

A inclusão de D. rufolimbata no gênero Cochabamba, no entanto, deve ser cautelosa e não definitiva. O gênero Diabrotica Chevrolat, considerado um problema clássico na taxonomia de Galerucinae, inclui cerca de 338 espécies (Smith \& Lawrence, 1967; Seeno \& Wilcox, 1982). Todos os gêneros que compõem a seção Diabroticites foram criados a partir de novas combinações com espécies que foram originalmente descritas em Diabrotica. Nunca houve um estudo taxonômico ou filogenético detalhado do gênero ou da seção de gêneros, mas os autores que revisaram os tipos de Diabroticites (Smith \& Lawrence, 1967) indicam, devido à grande variabilidade encontrada entre os táxons incluídos, que há grande probabilidade de que Diabrotica e diversos outros gêneros de Diabroticites sejam merofiléticos. Considerando, também, os resultados da análise posterior (que excluiu P. teinturieri, Fig. 4), na qual o terminal D. rufolimbata foi representado como um grupo irmão do clado formado pelas espécies de Cochabamba, conclui-se que a posição taxonômica dessa espécie necessita de investigação mais aprofundada. Ainda assim, é necessário que D. rufolimbata seja transferida para o gênero Cochabamba, de forma que este constitua um clado. Tem-se, portanto, que Cochabamba inclui as seguintes espécies:

1. C. chacoensis (Bowditch, 1911);

2. C. chrysopleura (Harold, 1875);

3. C. diversicolor (Baly, 1890);

4. C. erythrodera (Baly, 1879);

5. C. marginata (Harold, 1875) - espécie-tipo;

6. C. mera Bechyné, 1956;

7. C. polychroma Bechyné, 1956;

8. C. rufolimbata (Baly, 1879) (comb. nov.);

9. C. rugulosa (Baly, 1886); 
10. C. variolosa (Jacoby, 1878);

11. C. n. sp. (sp. nov.).

\subsubsection{Redescrição e discussão dos caracteres do gênero Cochabamba}

\section{Cochabamba Bechyné, 1955}

Cochabamba Bechyné, 1955: 6; Smith \& Lawrence, 1967: 27, 146; Bechyné \& Bechyné, 1969: 9; Wilcox, 1972: 343.

Espécie-tipo. Diabrotica marginata Harold, 1875, por designação original.

Diagnose. Pilosidade muito densa que cobre o metepisterno (e que pode impedir a visualização da sua escultura) e, às vezes, também áreas adjacentes, de coloração amarelada ou acinzentada e comprimento médio a longo. Epipleuras fortemente inclinadas, visíveis lateralmente por todo o comprimento elitral. Antenômeros II e III curtos (comprimento de ambos os antenômeros somados não ultrapassa o comprimento do antenômero IV). Olhos grandes, ocupando $2 / 3$ ou mais da largura total da cabeça. Espaço genal reduzido, menos de 1/4 do diâmetro ocular máximo.

Sinapomorfias. Olhos grandes, 1(1); antenômero III mais curto do que o antenômero $\mathrm{V}, 8(1)$; pronoto aproximadamente tão largo quanto longo, 11(1) e saco interno do lobo-médio com quatro escleritos, 45(2).

Forma do corpo. Quanto ao formato geral do corpo, ovalado (Figs. 12a-h e 13a-c), lateralmente convexo, os membros de Cochabamba são bastante similares aos demais gêneros incluídos no grupo dos Diabroticites, motivo pelo qual parte da descrição torna-se redundante, apesar de necessária.

Coloração geral do tegumento. Variável, com padrões gerais esverdeados $(C$. marginata, C. mera, C. erythrodera, C. variolosa), avermelhados ( $C$. chrysopleura, $C$. erythrodera), acastanhados ( $C$. erythrodera, C. polychroma), negros ( $C$. chacoensis) ou mesclados (C. rugulosa, C. n. sp).

Pilosidade geral. A presença e a distribuição das cerdas, principalmente na superfície ventral, é importante para a caracterização do gênero, que apresenta pilosidade muito densa no metepisterno, que pode encobrir completamente a visualização da escultura do tegumento, de coloração amarelada ou esbranquiçada, formada por cerdas de comprimento moderadamente longo a longo. Essa pilosidade densa pode também encobrir escleritos adjacentes em algumas espécies. A distribuição das cerdas na cabeça pode ser utilizada para diferenciar algumas espécies. A pilosidade das antenas e pernas é invariável no gênero, sendo densa, formada por cerdas longas ou moderadamente longas, com algumas cerdas eretas nos artículos apicais. De maneira geral podem ser observadas cerdas curtas, muito finas, enfileiradas nas margens anterior e posterior do pronoto, além de cerdas igualmente curtas e muito finas, eretas, distribuídas de maneira esparsa na superfície 
elitral em todas as espécies. Os ventritos geralmente apresentam pilosidade densa (Figs. 16a-d), formada por cerdas de comprimento moderadamente longo a longo, de coloração amarelada ou esbranquiçada, que podem encobrir parcialmente a visualização da escultura dos escleritos em algumas espécies, principalmente na margem posterior de cada ventrito, onde as cerdas se aglomeram. Em certas partes do corpo, como na cabeça, pronoto e calo do hipômero, a pontuação do tegumento relacionada à pilosidade pode ser diferenciada, quando examinada ao estereomicroscópio comum, daquela relacionada às aberturas glandulares, através de critérios como posição, distribuição e tamanho (Figs. 15b-d).

Cabeça (Fig. 15a). Estreita (largura menor do que a largura do pronoto); hipognata. Espaço genal reduzido. Vértice defletido, podendo apresentar aberturas glandulares e sulcos. Calos antenais desenvolvidos, ovóides a sub-retangulares, pouco maiores do que as cavidades antenais, podendo ter coloração diferente do restante da cabeça, geralmente mais clara. Olhos grandes (ocupam cerca de $2 / 3$ ou mais da largura total da cabeça em vista dorsal). Linhas orbitais bem marcadas, geralmente próximas da margem do olho na linha do vértice, adjacente às quais há uma cerda de comprimento longo, inserida em um ponto grosso, na porção anterior da cabeça em vista frontal (Fig. 15a). Cavidades antenais arredondadas, inseridas em posição mediana em relação à linha mediana do comprimento dos olhos, próximas entre si (distância entre as cavidades é menor do que o diâmetro individual), com bordas salientes. Antenas (Fig. 9e) longas (cerca de 2/3 do comprimento do corpo), filiformes, com 11 antenômeros, em geral dimórficas, sendo que a base dos artículos é quase tão larga quanto o ápice, nos machos, e mais estreita do que o ápice, nas fêmeas.

Peças bucais (Figs. 22a-f). Clípeo estreito (Figs. 7a-f e 8a-d), aproximadamente retangular, em geral escuro. Labro geralmente castanho-escuro, mais largo do que longo, com a margem anterior, levemente arredondada e ligeiramente emarginada no centro e a basal, reta, com apódemas laterais; presença de fileira de seis cerdas inseridas em pontos grossos na linha mediana (Fig. 22a). Epifaringe membranosa, com fileira de cerdas curtas, grossas, na margem anterior (Fig. 22b). Mandíbulas simétricas, subtriangulares (Figs. 22e, f); face externa convexa, presença de inúmeras cerdas curtas na superfície mediana; região incisiva da margem interna com três dentes, sendo o basal menor; região molar ovóide, superfície esculpida com uma série de fileiras longitudinais de dentículos. Maxilas (Fig. 22c) com cardos mais longos do que largos, presença de numerosas cerdas medianas na porção apical; estipes divididos em basestipe e medioestipe subiguais, presença de poucas cerdas longas nos basestipes; gáleas desenvolvidas, mais longas do que largas, com ápice arredondado, presença de numerosas cerdas longas no ápice; lacínias mais largas do que longas, com ápice arredondado, presença de numerosas cerdas longas no ápice e na margem interna; palpos maxilares mais longos do que largos, ultrapassando a gálea e a lacínia em comprimento; 4-articulados, artículo distal com ápice afilado. 
Lábio (Fig. 22d) com pós-mento subtrapezoidal, com pilosidade esparsa; pré-mento sub-retangular, presença de poucas cerdas na porção mediana; lígula arredondada, palpos labiais, 3-articulados, presença de cerdas esparsas, longas, eretas no segundo artículo.

Tórax. Pronoto (Figs. 10a-f e 11a-d) tão longo quando largo, presença de depressões variáveis na região discal, pontuação geral variável, presença de aberturas glandulares na porção anterior (Fig. 15b), próximas às margens anterior e laterais, presença de quatro cerdas longas, uma em cada ângulo, inseridas em pontos grossos e profundos, margens dos ângulos posteriores inclinadas formando um ângulo obtuso com a linha mediana do pronoto, fóvea bem definida, elevada, margens laterais ligeiramente sinuosas no terço basal. Cavidades pro- e mesocoxais arredondadas, próximas entre si, fechadas; cavidades meta-coxais transversas, ovaladas, afiladas lateralmente, transversais ao tórax, abertas. Élitros glabros, pontuados ou pontuados e estriados, espessura dos pontos variável.

Asas membranosas (Fig. 22h). Veias RA e MP fortemente esclerotizadas; veias AA, CuA e AP pouco esclerotizadas. Região basal das veias MP e AA fundidas à veia $\mathrm{SC}$; veia AP curta, sem conexões. Célula radial delimitada fracamente. Margem posterior com franja de cerdas curtas e finas.

Pernas e dimorfismo sexual. Pernas (Fig. 22g) subiguais, longas (comprimento total maior do que metade do comprimento elitral). Coxas das pernas pro- e mesotorácicas, arredondadas, coxas das pernas metatorácicas, ovaladas. Trocânteres subtriangulares, reduzidos. Fêmures alongados, com extremidade apical estreitada. Tíbias alongadas, largura basal aumentando gradualmente até a extremidade apical, dimórficas quanto à presença de esporões tibiais (presentes em todas as pernas, nas fêmeas, e apenas no par metatorácico, nos machos). Tarsos pseudotetrâmeros, tarsômero I de sub-quadrado a sub-retangular, dimórfico (presença de discos adesivos ocupando quase toda a superfície ventral, nos machos - Figs. 16e, f), tarsômero II sub-retangular, tarsômero III bilobado, presença de pilosidade densa, formada por cerdas de comprimento longo. Demais tarsômeros iguais em ambos os sexos, sendo o tarsômero IV muito pequeno, inconspícuo, e o tarsômero V alongado, com garras bífidas (Fig. 15h).

Abdômen. Ventritos (Fig. 16a-d) mais largos do que longos, diminuindo em largura gradualmente até o ventrito $\mathrm{V}$, o qual é subtrapezoidal com emarginação mediana na margem posterior, nos machos de algumas espécies (Fig. 16a, d). Tergito VIII geralmente exposto, mais esclerotizado do que os precedentes, de coloração e pilosidade semelhantes ao observado para os ventritos.

Edeago (Fig. 5c). Tégmen em forma de " $\mathrm{T}$ " ou "V", de comprimento aproximadamente igual a metade do comprimento do lobo-médio. Lobo-médio (Fig. 17b, e, h, k, n, q) fortemente côncavo, porção apical afilada e de comprimento variável (Fig. 17a, d, g, j, m, p), placa dorsal formada por lobos desiguais, sendo o anterior com ápice abobadado, que pode ser afilado em maior ou menor grau, em algumas espécies; saco interno com três, quatro ou cinco escleritos, de formato variável (Fig. 17c, f, i, l, o); 
spiculum gastrale em forma de "V".

Genitália feminina (Fig. 5b). Esternito VIII (Fig. 21a-g) subtriangular, trapezoidal ou pentagonal fracamente esclerotizado, presença de cerdas no ápice; spiculum ventrale alongado, com ápice alargado, retangular, geralmente ligeiramente convexo, atingindo cerca de metade do comprimento abdominal total. Palpos vaginais (Fig. 19a-f) alongados, nunca mais longos do que o spiculum ventrale, grau de esclerotização variável, presença de cerdas na região apical. Bursa copulatrix (Fig. 18a-e) com diferentes níveis de esclerotização na região central, podendo formar anéis ou placas bem definidos. Uma única espermateca (Fig. 20a-f), em forma de "C" ou "S", em geral alongada com região basal fortemente côncava e ápice acuminado, ducto em geral longo e simples. Glândula da espermateca não observada (provavelmente destruída no processo de preparação para a dissecção, como é comum para diversos crisomelídeos).

Distribuição geográfica: Costa Rica, Panamá, Equador, Peru, Venezuela, Colômbia, Brasil, Argentina e Paraguai.

Discussão dos principais caracteres. O gênero segue a tendência observada em Chrysomelidae para a variabilidade na coloração. No entanto, os padrões observados são de grande importância para identificar os táxons específicos, especialmente quando combinados a outros caracteres (ainda que haja alguma variação na coloração intra-específica, provavelmente resultado dos diferentes modos de captura e conservação utilizados, bem como na idade dos exemplares no momento da fixação), principalmente aqueles referentes aos élitros.

Não foi observada variação interespecífica considerável na morfologia das peças bucais (Fig. 22a-f) para diferenciar as espécies entre si. Além disso, as peças bucais observadas nas espécies de Cochabamba são muito semelhantes àquelas descritas para outros gêneros da seção Diabroticites, sendo praticamente indistinguíveis, por exemplo, das peças de parte do gênero Diabrotica, estudada por Krysan \& Smith (1987). Esses dados confirmam a idéia de que há pouca variabilidade nessas estruturas em um nível hierárquico específico, ou até mesmo, genérico.

Em comparação com os poucos estudos da genitália que incluem os Diabroticites, foi possível notar que esta não é uma fonte de caracteres bem definidos para as espécies, com variações ocorrendo principalmente nos escleritos do saco interno, nos machos, e nos palpos vaginais e bursa copulatrix, nas fêmeas. No entanto, quando foi possível dissecar diversos exemplares da mesma espécie, foi possível notar que tal variação é muito grande dentro das espécies para que se obtenha um conjunto estável de caracteres para defini-las por si só. Como observado para outras características em Chrysomelidae, caracteres de genitália devem, em geral, ser utilizados associados a outros para serem considerados diagnósticos específicos, ou mesmo genéricos. 
Chave de identificação para as espécies de Cochabamba Bechyné, 1955

1. Tegumento elitral com pontuação fina a média, ou formando padrão reticulado, sem

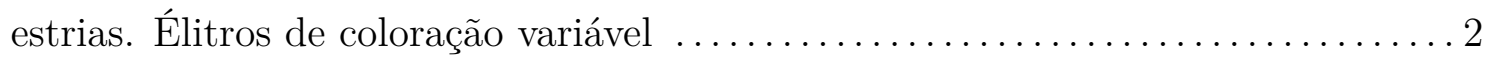

1'. Tegumento elitral com pontuação formada por pontos grossos, com estrias elitrais longitudinais. Élitros castanho-escuros a negros (Fig. 12a) - Bolívia (La Paz, Cochabamba, Santa Cruz) e Paraguai (Central) ..................chacoensis

2(1). Tegumento elitral com pontuação formando padrão reticulado $\ldots \ldots \ldots \ldots \ldots . . .3$

2'. Tegumento elitral com pontuação fina a média $\ldots \ldots \ldots \ldots \ldots \ldots \ldots \ldots \ldots \ldots$

3(2). Élitros de coloração igual à coloração das margens laterais $\ldots \ldots \ldots \ldots \ldots \ldots .4$

3'. Élitros de coloração diferente da coloração das margens laterais (Fig. 12e) - Brasil (Pará, Minas Gerais, Espírito Santo, Rio de Janeiro, São Paulo, Santa Catarina) .

C. marginata

4(3). Élitros com mancha castanho-escura adjacente à margem apical (Fig. 12b) Colômbia (Caldas, Cauca) e Peru (Piura) .................. chrysopleura

4'. Élitros sem manchas ou com manchas de outras cores (Fig. 13b) - Equador e Peru

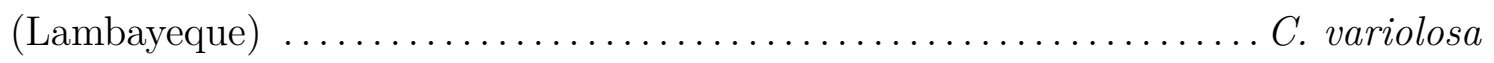

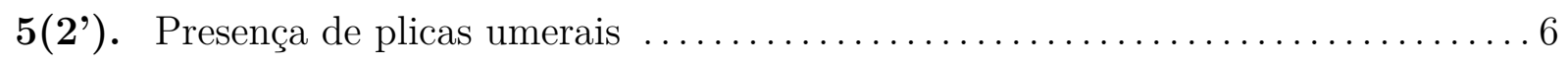

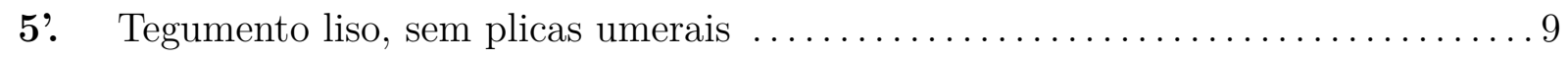

6(5). Plicas umerais conspícuas, em toda a superfície elitral $\ldots \ldots \ldots \ldots \ldots \ldots \ldots \ldots 7$

6. Plicas umerais pouco salientes, porção mediana dos élitros lisa (Fig. 12c) - Equador

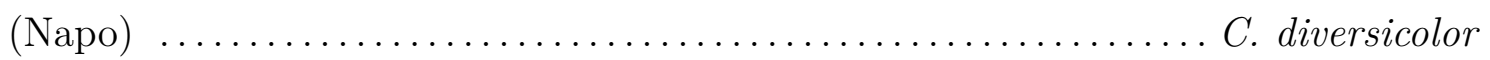

7(6). Élitros com mais de uma coloração; pubescência da superfície ventral

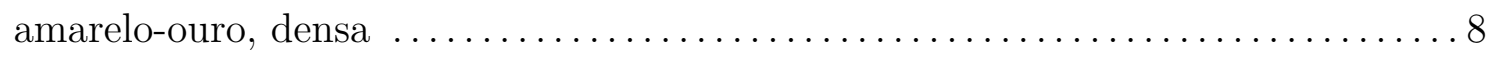

7'. Élitros de coloração única, sem manchas, verdes-claros; pubescência da superfície ventral esbranquiçada, moderadamente densa (Fig. 12f) - Panamá (Cocle) e

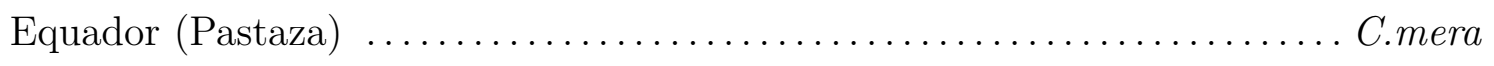

8(7). Élitros de duas cores: metade anterior negra, metade posterior avermelhada a amarelada (Fig. 13c) - Peru (Cuzco) ......................... n. sp.

8' Élitros com manchas arredondadas, verde-claras, adjacentes ao ápice, ocupando cerca de 1/4 do comprimento elitral (Fig. 13a) - Equador e Peru (Pasco) .........

C. rugulosa 
9(5'). Metepisterno e escleritos adjacentes completamente encoberto por pilosidade densa, amarelada, que impede a visualização do tegumento $\ldots \ldots \ldots \ldots \ldots \ldots \ldots$

9'. Metepisterno e escleritos adjacentes encobertos por pilosidade moderadamente densa, esbranquiçada. Antenas verde-claras; pronoto verde-claro, liso; élitros de coloração verde-clara, com margens laterais alaranjadas (Fig. 12h) - Brasil (Goiás, Mato Grosso, Minas Gerais, São Paulo e Espírito Santo) .......... C. rufolimbata

10(9). Antenas de coloração verde-clara; pronoto castanho-avermelhado a castanho-amarelado; élitros de coloração verde-clara, verde-escura ou castanho-esverdeada, superfície de aspecto liso e brilhante; pubescência da superfície ventral amarelo-clara (Fig. 12d) - Costa Rica (Puntarenas, San José,

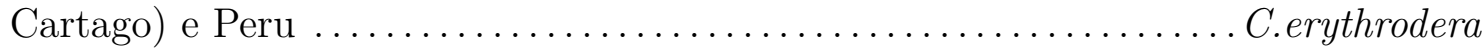

10'. Antenas de coloração heterogênea, sendo os artículos basais esverdeados e os apicais, amarelados; pronoto verde-escuro a castanho-escuro; élitros verde-escuros a castanho-esverdeados, superfície de aspecto liso e opaco; pubescência da superfície ventral amarelo-ouro (Fig. 12g) - Brasil (Minas Gerais, São Paulo, Santa Catarina), Argentina (Misiones) e Paraguai (Central) ................... . polychroma 


\subsubsection{Redescrição e discussão dos caracteres das espécies do grupo-interno e descrição de espécie nova}

\section{Cochabamba chacoensis (Bowditch, 1911)}

(Figs. 7a, 10a, 12a, 14a, 17a-c, 18a, 19a, 20a, 21a, 23, 24)

Diabrotica chacoensis Bowditch, 1911: 96; Weise, 1924: 29 (catálogo); Blackwelder, 1946: 680 (checklist); Bechyné, 1955a: 141 (checklist). Holótipo: D. chacoensis Type (M) Bow (MCZC), fotografia examinada; Parátipo: D. chacoensis Paratype, (MCZC), fotografia examinada.

Cochabamba chacoensis; Bechyné, 1955: 6; Smith \& Lawrence, 1967: 47, 146 (revisão de tipos); Wilcox, 1972: 338 (catálogo); Cabrera, 1999: 69, 74 (redescrição).

Diagnose. Antenas esverdeadas ou amareladas, sendo os artículos apicais castanhos. Pronoto aproximadamente tão longo quanto largo, de castanho-escuro a negro; élitros de castanho-escuros a negros, presença de estrias longitudinais por toda a sua extensão, pontuação do tegumento interestrial formada por pontos grossos e relativamente profundos; pubescência da superfície ventral esbranquiçada a amarelo-ouro.

Comprimento. 6-8 $\mathrm{mm}$.

Coloração geral. (Fig. 12a) Negra. Antenas esverdeadas ou amarelo-claras, sendo os artículos VIII-XI castanhos. Metepisterno castanho-amarelado e metepímero castanho-amarelado. Metasterno castanho-escuro na região central, castanho-claro a castanho-amarelado lateralmente. Pernas negras, exceto trocânteres e fêmures, que são amarelo-claros. Ventrito V e os últimos tergitos castanho-avermelhados.

Pilosidade geral. Região dorsal com pilosidade esparsa, cerdas curtas a longas, esbranquiçadas. Cabeça com poucas cerdas, longas, esbranquiçadas, abaixo da linha dos olhos. Pilosidade longa, densa, esbranquiçada ou amarelo-ouro cobrindo totalmente o tegumento do mesosterno, mesepisterno, mesepímero, metepímero, metepisterno, ventritos e as margens laterais do metasterno.

Cabeça (Fig. 7a). Aspecto liso e brilhante. Pontuação esparsa e fina; presença de aberturas glandulares localizadas logo acima dos calos antenais.

Tórax. Pronoto com pontuação esparsa, pontos finos; presença de duas leves depressões circulares no terço basal (Fig. 10a). Élitros estriados, estrias marcadas por sulcos (Fig. 14a), tegumento com pontuação densa, pontos grossos.

Edeago (adaptado de Cabrera, 1999). Lobo-médio (Figs. 17a, b) com ápice acuminado e ápice da placa dorsal alongado em relação às demais . Saco interno com cinco escleritos (Fig. 17c) - descritos seguindo a sua localização no interior do lobo-médio -: o mais apical recurvado e denteado na porção anterior; o mediano maior, ocupando grande parte do saco interno e mais largo na porção basal; dois basais subiguais e o látero-basal alongado com pouco mais da metade do comprimento do mediano. 
Genitália feminina. Spiculum ventrale alongado, fortemente esclerotizado, comprimento maior do que o a porção mediana da bursa copulatrix (Fig. 21a). Palpos vaginais alongados (cerca de $1 / 3$ do comprimento do spiculum ventrale) ligeiramente estreitados a partir do terço do comprimento, margem basal proeminente e arredondada (Fig. 19a). Bursa copulatrix com região mediana bastante esclerotizada, formando um anel estreitado na porção mesal, com superfície esculturada com pequenas papilas (Fig. 18a). Espermateca com porção basal fortemente côncava e ápice acuminado (Fig. 20a).

Material examinado. BolíviA. La Paz: Coroico, XII.1949 (A. Martinez leg.), 1 fêmea (MZSP). Cochabamba: Yungas del Palmar, III.1956, 2000m (Dirings leg.), 1 fêmea (MZSP); idem, sem data (Zischka \& Ew. Reitter leg.), 2 fêmeas (NHMB) e 1 fêmea (NRM). Santa Cruz: Cerro San Fermín, sem data e coletor, 1 fêmea (NHRS). Sem localidade, data e coletor, 1 fêmea (USNM).

Distribuição geográfica. Bolívia e Paraguai (Figs. 23e 24).

Discussão. O reconhecimento dessa espécie é inequívoco dentro do gênero, uma vez que trata-se da única espécie monocromática na superfície dorsal (com exceção das antenas) e com élitros estriados.

A genitália maculina dessa espécie não foi estudada. A caracterização da genitália foi baseada na redescrição e ilustrações de Cabrera (1999). A autora não descreveu o tégmen, tampouco o spiculum gastrale (se presente), dessa espécie. Apresenta espermateca semelhante à de C. marginata. 


\section{Cochabamba chrysopleura (Harold, 1875)}

(Figs. 7b, 10b, 12b, 14b, 18b, 19b, 20b, 21b, 23)

Diabrotica chrysopleura Harold, 1875: 92; Baly, 1890: 85; Blackwelder, 1946: 680 (checklist); Bechyné, 1955: 6 (checklist). Tipo não localizado, possivelmente perdido (Smith \& Lawrence, 1967).

Cochabamba chrysopleura; Bechyné, 1955: 6; Smith \& Lawrence, 1967: 48,146 (revisão de tipos); Wilcox, 1972: 343 (catálogo).

Diagnose. Antenas amareladas, sendo os artículos apicais mais escuros, castanhos. Pronoto aproximadamente tão longo quanto largo, de coloração castanho-escura a negra. Élitros avermelhados, com manchas castanho-escuras a negras adjacentes à margem apical, pontuação de aspecto reticulado. Pubescência da superfície ventral esbranquiçada ou amarelo-ouro.

Comprimento. $8-9 \mathrm{~mm}$.

Coloração geral (Fig. 12b) Castanho-escura avermelhada. Cabeça negra. Antenas amareladas, sendo os artículos apicais mais escuros, castanhos. Clípeo e peças bucais castanho-amareladas. Pronoto e prosterno negros. Mesosterno, mesepisterno, mesepímero e metepisterno castanho-escuros avermelhados. Metasterno castanho-escuro na região central castanho-avermelhado lateralmente. Metepímero castanho-escuro avermelhado. Élitros avermelhados, com manchas castanho-escuras a negras no ápice e, às vezes, na porção umeral. Escutelo negro. Pernas amareladas. Ventritos castanho-escuros avermelhados a negros.

Pilosidade geral. Região dorsal com pilosidade esparsa, cerdas curtas a longas, esbranquiçadas. Cabeça com poucas cerdas, longas, esbranquiçadas, abaixo da linha dos olhos. Pilosidade longa, densa, esbranquiçada ou amarelo-ouro cobrindo totalmente o tegumento do mesosterno, mesepisterno, mesepímero, metepímero, metepisterno, ventritos e margens laterais do metasterno.

Cabeça (Fig. 7b). Aspecto liso e brilhante. Pontuação esparsa, fina.

Tórax. Pronoto (Fig. 10b) com pontuação esparsa, pontos finos; presença de duas leves depressões circulares medianas na metade basal. Élitros com pontuação reticulada (Fig. 14b).

Edeago. Não observado.

Genitália feminina. Spiculum ventrale (Fig. 21b) alongado, com comprimento igual a 1,5 vez o comprimento da porção mediana da bursa copulatrix. Palpos vaginais (Fig. 19b) alongados (cerca de $1 / 3$ do comprimento do spiculum ventrale), relativamente pouco esclerotizados. Bursa copulatrix (Fig. 18b) com região central moderadamente esclerotizada. Espermateca (Fig. 20b) com porção basal moderadamente côncava e ápice expandido. 
Material examinado. Colômbia. Caldas: Manizales, sem data (A. M. Pateno leg.), 1 fêmea (IRSNB). Cauca: sem localidade, data e coletor, 5 fêmeas (NHMB); idem, 1 fêmea (NHRS); sem localidade, 1959 (F. Monrós leg.), 1 fêmea (USNM); idem, 2 fêmeas (NRM). PERU: Piura: Huascaray, 21-22.VII.1971 (C. H. T. Townsend leg.), 1 fêmea (USNM); sem localidade, 12-16.IX.1911 (sem coletor), 1 fêmea (USNM). Sem localidade, data e coletor, 2 fêmeas e 1 macho (IRSNB); idem, 3 fêmeas (NHRS); idem, 1 fêmea (USNM).

Distribuição geográfica. Colômbia e Peru (Fig. 23).

Discussão. Essa espécie pode ser confundida com C. diversicolor pela coloração avermelhada dos élitros, porém é prontamente distinguível desta pelo padrão reticulado da pontuação, pelas manchas e pela coloração castanha do restante do corpo. 


\section{Cochabamba diversicolor (Baly, 1890)}

(Figs. 7c, 10c, 12c, 14c, 23)

Diabrotica diversicolor Baly, 1890: 86; Blackwelder, 1946: 681 (checklist). Holótipo: 49819/ ex Mus Murray/ Fry Coll. 1905-100/ Type/ diversicolor/ Equador Quito (BMNH), examinado.

Cochabamba diversicolor; Smith \& Lawrence, 1967: 59 (revisão de tipos), Wilcox, 1972: 343 (catálogo).

Diagnose. Antenas de coloração heterogênea, sendo os artículos basais e medianos esverdeados e os apicais, castanho-escuros. Pronoto aproximadamente tão longo quanto largo, castanho-escuro. Élitros avermelhados, pontuação formada por pontos moderadamente grossos e superficiais. Pubescência da superfície ventral amarelo-ouro.

Comprimento. 6-9 $\mathrm{mm}$.

Coloração geral (Fig. 12c). Castanha. Cabeça negra. Antenas esverdeadas, sendo os artículos apicais castanho-escuros. Clípeo, peças bucais, pronoto e prosterno negro. Mesosterno e mesepisterno castanho-escuros avermelhados. Mesepímero amarelado. Metepisterno castanho-amarelado. Metasterno castanho-escuro na região central e castanho-claro a castanho-amarelado lateralmente. Metepímero amarelado. Élitros avermelhados, podendo ter a base ligeiramente escurecida. Escutelo negro. Pernas castanhas, exceto pelas coxas e trocânteres, que são esverdeados. Ventritos amarelados.

Pilosidade geral. Região dorsal com pilosidade esparsa, cerdas curtas a longas, esbranquiçadas. Cabeça com poucas cerdas, longas, esbranquiçadas, abaixo da linha dos olhos. Pilosidade média a longa, densa, esbranquiçada ou amarelo-ouro cobrindo totalmente o tegumento do mesosterno, mesepisterno, mesepímero, metepímero, metepisterno e margens laterais do metasterno.

Cabeça (Fig. 7c). Aspecto liso e opaco. Pontuação densa, fina.

Tórax. Pronoto (Fig. 10c) com pontuação densa, fina; presença de duas leves depressões circulares na metade basal e uma triangular, central. Élitros (Fig. 14c) com pontuação densa, pontos moderadamente grossos; presença de três plicas umerais, laterais, pouco demarcadas.

Edeago. Não observado.

Genitália feminina. Não observada.

Material examinado. Equador. Napo: Baeza, 14.IV.1977 (Elaine R. Hodges leg.), 2macho (USNM); sem localidade, data e coletor, 1 fêmea (USNM).

Distribuição geográfica. Equador (Fig. 23).

Discussão. C. diversicolor pode ser confundida com C. chrysopleura pela coloração avermelhada dos élitros. No entanto, aquela é prontamente distinguível desta pela pontuação elitral, que é moderadamente grossa, pela presença de plicas umerais laterais e pela coloração das demais partes corporais. 


\section{Cochabamba erythrodera (Baly, 1879)}

(Figs. 7d, 10d,12d, 14d, 17d-f, 18c, 19c, 20c, 21c, 23)

Diabrotica erythrodera Baly, 1879: 82; Baly, 1890: 83; Jacoby, 1891: 88; Blackwelder, 1946: 681 (checklist). Holótipo: Type/ Diabrotica erythrodera Baly Peru/ Baly Coll. (BMNH), examinado.

Cochabamba erythrodera; Smith \& Lawrence, 1967: 64, 146 (revisão de tipos); Wilcox, 1972: 344 (catálogo).

Diagnose. Antenas de coloração amarelada, sendo o último artículo castanho-escuro e os imediatamente anteriores mais claros do que os demais. Pronoto aproximadamente tão longo quanto largo, de castanho-avermelhado a castanho-amarelado, com região mediana mais escura. Élitros de verde-escuros a castanho-esverdeados, superfície de aspecto liso e brilhante, com pontuação formada por pontos muito finos e superficiais, pouco conspícuos. Pubescência da superfície ventral amarelo-clara.

Comprimento. 8-9 $\mathrm{mm}$.

Coloração geral (Fig. 12d) Castanha. Antenas amareladas, sendo o último artículo castanho-escuro e os imediatamente anteriores mais claros do que os demais. Pronoto de castanho-avermelhado a castanho-amarelado com manchas centrais castanho-escuras a negras, ou então a porção central é completamente castanho-escura a negra. Mesepisterno e mesepímero esverdeados ou castanho-amarelados a castanho-escuros. Metasterno castanho-escuro na região central e castanho-amarelado, castanho-escuro avermelhado, ou completamente castanho-escuro lateralmente. Élitros esverdeados, variando de verde-escuros a amarelados e castanho-esverdeados. Escutelo castanho-escuro a negro. Pernas esverdeadas, variando à maneira da coloração elitral; coxas esverdeadas a castanhas; trocânteres e fêmures esverdeados, castanho-amarelados a castanho-escuros; tíbias e tarsos castanho-claros a castanho-escuros. Ventritos castanho-amarelados a castanho-escuros avermelhados.

Pilosidade geral. Região dorsal com pilosidade esparsa, cerdas curtas a longas, esbranquiçadas. Cabeça com poucas cerdas, longas, esbranquiçadas, abaixo da linha dos olhos. Pilosidade longa, densa, esbranquiçada ou amarelo-clara cobrindo totalmente o tegumento do mesosterno, mesepisterno, mesepímero, metepímero, metepisterno, ventritos e as margens laterais do metasterno.

Cabeça (Fig. 7d). Aspecto liso e brilhante. Pontuação esparsa, fina; presença de aberturas glandulares localizadas logo acima dos calos antenais.

Tórax. Pronoto com pontuação esparsa, pontos finos; presença de duas leves depressões circulares medianas (Fig. 10d). Élitros com pontuação densa, pontos finos.

Edeago. Tégmen em forma de "V". Lobo-médio (Figs. 17d, e) alongado, com ápice estreito. Saco interno com quatro escleritos (Fig. 17f) - descritos seguindo a sua 
localização no interior do lobo-médio -: o mais apical expandido e denteado, os dois medianos côncavos, subiguais, e o lateral reto, afilado.

Genitália feminina. Spiculum ventrale (Fig. 21c) alongado, ligeiramente mais longo do que o comprimento da porção mediana da bursa copulatrix, moderadamente esclerotizado. Palpos vaginais (Fig. 19c) mais curtos do que o esternito VIII. Bursa copulatrix (Fig. 18c) com porção central pouco esclerotizada em relação às outras espécies, formando uma placa dorsal cujas bordas são recurvadas. Espermateca (Fig. 20c) estreita em relação às outras espécies, porção basal moderadamente convexa, porção apical recurvada, comprimida dorsoventralmente e com ápice afilado.

Material examinado. Costa RicA. Puntarenas: Coto Brus, Est. Biol. Las Alturas, V.1992, 1500m (M. Ramirez leg.), 31 fêmeas e 57 machos (INBIO); Est. Pittier, 23-2.I-II.1995, 1670m (M. Iobo leg.), 55 fêmeas e 62 machos (INBIO); idem, 21-28.VI.1995, 1670m (E. Navarro leg.), 30 fêmeas e 35 machos (INBIO); idem, 22-28.VI.1995, 1670m (A. Azofeita leg.), 11 machos (INBIO); idem, 21-4.V-VI.1995, 1800m (E. Fletes leg.), 14 fêmeas e 7 machos (INBIO); idem, 22-28.VI.1995, 1800-2050m (B. Gamboa leg.), 1 macho (INBIO); idem, 22-4.VI-VII.1995 (E. Alfaro leg.), 3 machos (INBIO); idem, 23-9.VIII-IX.1995, 1670m (M. Morada leg.), 3 machos (INBIO); idem, 23-13.VIII-IX.1995, 1670m (E. Navarro leg.), 4 machos (INBIO); idem, 26-5.IX-X.1995 (E. Navarro leg.), 2 machos (INBIO); idem, 4-22.I.1996, 1670m (E. Navarro \& de Luz leg.), 1 macho (INBIO). San José: Est. Cuerici, El Mirador, 4 km al E. Villa Mills, 29.VI.1996, 2900m (B. Gamboa leg.), 1 fêmea (INBIO). Cartago: Reserva Rio Macho, Est. Ojo de Agua, 24-26.II.1998, 2960m (E. Alfaro leg.), 1 macho (INBIO).

Distribuição geográfica. Costa Rica e Peru (Fig. 23).

Discussão. Essa espécie apresenta variação no padrão de coloração corporal, com três composições identificadas (a partir dos élitros): um padrão verde-escuro, um mais claro e um castanho-esverdeado. Outra peculiaridade dessa espécie é a superfície dorsal do corpo muito lisa, de pontuação fina, o que confere um brilho não observado nos exemplares estudados dos outros táxons (ainda que essa característica possa ser resultado direto de artefato da técnica empregada na captura e conservação dos espécimes). A dissecção de exemplares representantes dos três padrões de coloração observados permitiu reconhecer que todos fazem parte de uma única espécie, C. erythrodera. A genitália, tanto do macho, quanto da fêmea, em geral é relativamente menos esclerotizada do que o observado para as outras espécies estudadas. Apresenta espermateca relativamente menor e mais estreita, com ápice afilado, sem ser acuminado como nas outras espécies estudadas. O lobo-médio do edeago apresenta ápice mais estreito do que em C. marginata, por exemplo, além de ser mais alongado. 


\section{Cochabamba marginata (Harold, 1875)}

(Figs. 7e, 10e, 12e, 14e, 17g-i, 18d, 19d, 20d, 21d, 23, 24)

Diabrotica marginata Harold, 1875: 93; Gahan, 1891: 523; Christensen, 1943: 483, 487; Blackwelder, 1946 (checklist). Lectótipo: Bras./ marginata (Diabrotica) m. typ./ Ex-Musaeo E. Harold (MNHN), não examinado. Paralectótipo: “3” (MNHN), não examinado.

Cochabamba marginata; Bechyné, 1955: 6; Bechyné, 1965: 261; Bechyné \& Bechyné, 1962: 48; Smith \& Lawrence, 1967: 146; Bechyné \& Bechyné 1969; Wilcox, 1972: 344 (catálogo).

Diagnose. Antenas de coloração amarelada. Pronoto aproximadamente tão longo quanto largo, de coloração verde-clara a verde-escura. Élitros de coloração verde-clara a verde-escura, com margens laterais expandidas e de coloração castanho-amarelada, pontuação de aspecto reticulado. Pubescência da superfície ventral amarelo-clara a amarelo-ouro.

Comprimento. $7-12 \mathrm{~mm}$.

Coloração geral (Fig. 12e) Castanho-escura. Cabeça verde-clara. Antenas amareladas. Pronoto de verde-claro a verde-escuro, podendo apresentar manchas mais escuras sutis na porção central. Prosterno verde e mesosterno verdes. Metasterno com porção central castanho-escura e porções laterais castanho-claras a castanho-amareladas. Élitros de verde-claros a verde-escuros, com margens laterais de castanho-amareladas a alaranjadas. Escutelo castanho-escuro a negro. Pernas castanho-amareladas. Ventritos amarelados a castanhos.

Pilosidade geral. Região dorsal com pilosidade esparsa, cerdas curtas a longas, esbranquiçadas. Cabeça com poucas cerdas, longas, esbranquiçadas, abaixo da linha dos olhos. Pilosidade longa, densa, de amarelo-claro a amarelo-ouro cobrindo totalmente o tegumento do mesosterno, mesepisterno, e mesepímero, metepímero, metepisterno e ventritos e as laterais do metasterno.

Cabeça (Fig. 10e). Aspecto liso e brilhante. Pontuação esparsa, fina; presença de aberturas glandulares localizadas logo acima dos calos antenais.

Tórax. Pronoto (Fig. 10e) com pontuação densa, pontos finos; presença de duas leves depressões subtriangulares medianas no terço basal. Élitros (Fig. 12e) com pontuação reticulada; presença de espículos na superfície ventral da porção basal, próxima à margem central, formando o binding patch (Fig. 15f).

Edeago. Tégmen em "Y". Lobo-médio (Fig. 17g) com porção apical mais larga do que o observado para as outras espécies estudadas. Placa dorsal (Fig. 17h) de formato semelhante ao ápice do lobo-médio. Saco interno com quatro escleritos (Fig. 17i) descritos seguindo a sua localização no interior do lobo-médio -: o anterior denteado, os dois medianos côncavos, recurvados, e o lateral reto, afilado. 
Genitália feminina. Spiculum ventrale (Fig. 21d) alongado, de comprimento semelhante ao comprimento da porção mediana da bursa copulatrix, moderadamente esclerotizado. Palpos vaginais (Fig. 19d) alongados, moderadamente esclerotizados. Bursa copulatrix (Fig. 18d) com região posterior longa, com região central fortemente esclerotizada, formando um anel bem definido, tegmento ornamentado com pequenas papilas e cerdas curtas e grossas, esparsas. Espermateca com região basal fortemente côncava, ápice acuminado, alongado.

Material examinado. Brasil. Pará: Óbidos, XII.1959 (Dirings leg.), 1 macho (MZSP); idem, Baixo Amazonas, XII.1953 (Dirings leg.), 1 fêmea (MZSP); Cachimbo, X.1959 (Alvarenga leg.), 1 fêmea (MZSP) e 12 fêmeas (DZUP). Minas Gerais: Serra do Caraça, 27-5.XI-XII.1972 (Expedição MZUSP leg.), 2 fêmeas (MZSP) e 5 fêmeas (DZUP); Mar de Espanha, 25.XI.1904 (J. F. Zikán leg.), 1 fêmea (FIOC); idem, sem data (Heyne \& W. Berlin leg.), 1 macho (NHRS); Faz. Dos Campos, 19.XII.1915 (J. F. Zikán leg.), 1 macho (FIOC); Serra dos Cachos, Sul de Minas, 1600m (B. Pohl leg.), 1 fêmea (MZSP). Espírito Santo: Córrego Ita, X.1954, -m (W. Zikán col.), 1 fêmea (MNRJ); Faz. Jerusalém, 1.XII.1914 (J. F. Zikán col.), 1 fêmea (FIOC); sem localidade, data e coletor, 2 fêmeas e 2 machos (NHMB). Rio de Janeiro: Itatiaia, IV.1932 (D. Mendes leg.), 2 fêmeas (MNRJ); idem, 31.?.1933, 700m (W. Zikán leg.), 1 macho (NHMB); idem, XII.1933, 800m (S. Lopes \& R. Cunha leg.), 2 fêmeas e 1 macho (MNRJ); idem, 8.IX.1941 (J. F. Zikán leg.), 1 macho (FIOC); idem, 16.XII.1947 (J. F. Zikán leg.), 1 fêmea (FIOC); idem, XI.1947, 700m (W. Zikán leg.), 1 fêmea (MNRJ) ; idem, 2.I.1948 (J. F. Zikán leg.), 1 macho (FIOC); idem, 16.XI.1949, 700m (W. Zikán leg.), 1 fêmea (FIOC); idem, XI.1949, 700m (W. Zikán leg.), 1 fêmea (MNRJ); idem, XI.1950 (Travassos \& Dalcy leg.), 3 fêmeas e 1 macho (MNRJ); idem, II.1955 (Dirings leg.), 2 fêmeas e 3 machos (MZSP); idem, I.1960 (Dirings leg.), fêmea (MZSP); idem, II.1960 (Dirings leg.), 1 fêmea (MZSP); idem, 9.III.1962 (J. Halik leg.), 2 fêmeas (USNM); idem, XI.1962 (Dirings leg.), 1 macho (MZSP); idem, 4.IX.1962 (J. Halik leg.), 1 macho (MZSP); idem, I.1963 (Dirings leg.), 1 fêmea (MZSP); idem, 3.II.1963 (J. Halik leg.), 1 fêmea (MZSP) e 1 fêmea (USNM); idem, 5.II.1963 (J. Halik leg.), 2 machos (MZSP); idem, II.1964 (Dirings leg.), 1 fêmea e 1 macho (MZSP); idem, X.1965 (Dirings leg.), 1 macho (MZSP); idem, II.1966 (Dirings leg.), 12 fêmeas e 8 machos (MZSP); idem, II.1966 (sem coletor), 1 fêmea (MZSP); idem, I.1967 (Dirings leg.), 1 fêmea (MZSP); idem, II.1967 (Dirings leg.), 1 fêmea (MZSP); idem, IX.1967, 1100m (Dirings leg.), 2 machos (MZSP); idem, I.1968 (Dirings leg.), 2 fêmeas (MZSP); idem, XI.1968, 1110m (Dirings leg.), 1 fêmea (MZSP); idem, XI.1968 (Dirings leg.), 1 macho (MZSP); idem, I.1972, 1100m (Dirings leg.), 1 macho (MZSP); idem, I.1972 (Dirings leg.), 1 fêmea e 1 macho (MZSP); idem, XII.1960, 1100m (Dirings leg.), 1 fêmea (MZSP); idem, Maromba, 13.IX.1959, 1100m (sem coletor), 1 macho (FIOC); Tinguá, 1.XII.1969 (Martins \& Evangelista leg.), 1 macho (FIOC); Petrópolis, III.1941 (Parko leg.), 1 macho (MNRJ); idem, Alto da Masela, 7-8.I.1956, 1100m (Dalcy, Isolda \& N. Dias dos Santos leg.), 1 macho (MNRJ); Teresópolis, Fazenda Alpina, 11.XI.1945, 1000m (Wygod. leg.), 1 fêmea (MNRJ); 26.X.1957 (Machado-Barros \& Dalcy leg.), 1 macho (MNRJ); Serra dos Órgãos, XII.1940 (Parko leg.), 1 fêmea (MNRJ); Nova Friburgo, III.1969 (S. Fragoso leg.), 1 macho (MNRJ); V.1935 (D. M. Cochran leg.), 1 macho (USNM); 
Rio de Janeiro, Represa Rio Grande, IX.1960 (F. M. Oliveira leg.), 1 fêmea (MNRJ); Angra dos Reis, Jussaral, V.1934 (D. Mendes leg.), 1 fêmea (MNRJ); idem, VIII.1934 (Dario Mendes leg.), 1 macho (MNRJ); idem, IX.1934 (D. Mendes leg.), 2 fêmeas (MNRJ); idem, XI.1934 (L. Travassos leg.), 1 fêmea (MNRJ); idem, X.1934 (L. Trav \& Lopes leg.), 1 fêmea (MNRJ); idem, I.1935 (Dario Mendes leg.), 1 fêmea (MNRJ); idem, X.1935 (L. Trav. \& Lopes leg.), 2 fêmeas (MNRJ); idem, sem data (D. Mendes leg.), 1 fêmea (MZSP); Rezende, X.1950 (sem coletor), 2 machos (FIOC); Independência, sem data e coletor, 1 macho (MNRJ); sem localidade, data e coletor, 1 macho (MNRJ). São Paulo: Campos do Jordão, II.1938 (L. Travassos Filho leg.), 1 macho (MZSP); Pindamonhangaba, Eugênio Lefévre, 26.I.1962 (Expedição Departamento de Zoologia leg.), 1 macho (MZSP); idem, 26.II.1962 (Expedição Departamento de Zoologia leg.), 1 fêmea (MZSP); idem, 23.IX.1962 (Expedição Departamento de Zoologia leg.), 1 macho (MZSP); idem, 28.IX.1962 (Expedição Departamento de Zoologia leg.), 9 fêmeas e 12 machos (MZSP); 26.X.1962 (Expedição Departamento de Zoologia leg.), 2 fêmeas e 12 machos (MZSP); idem, 21.XII.1962 (Expedição Departamento de Zoologia leg.), 1 fêmea e 2 machos (MZSP); idem, 24.I.1963 (Expedição Departamento de Zoologia leg.), 5 fêmeas e 8 machos (MZSP); idem, III.1963 (Expedição Departamento de Zoologia leg.), 5 fêmeas e 1 macho (MZSP); Cantareira, III.1933 (Dirings leg.), 1 fêmea (MZSP); idem, 10.I.1938 (Zellibor-Hauff leg.), 1 macho (MNRJ); idem, 17.II.1960 (J. Halik leg.), 1 macho (USNM); idem, 1960 (F. Lane leg.), 1 macho (MZSP); idem, 2.I.1962 (J. Halik leg.), 1 macho (USNM); idem, 17.II.1962 (J. Halik leg.), 1 fêmea (USNM); idem, II.1962 (J. Halik leg.), 1 fêmea e 1 macho (MZSP); idem, 25.XI.1962 (J. Halik leg.), 1 fêmea (MZSP); idem, 1.III.1963 (J. Halik leg.), 1 fêmea (MZSP); idem, 8.IV.1963 (J. Halik leg.), 1 fêmea (USNM); idem, 29.XII.1963 (J. Halik leg.), 1 fêmea (MZSP); idem, 28.I.1964 (J. Halik leg.), 1 macho (MZSP); idem, 30.XI.1966 (J. Halik leg.), 2 fêmeas (MZSP); idem, 15.XI.1967 (J. Halik leg.), 3 fêmeas (MZSP); idem, 7.I.1968 (J. Halik leg.), 1 macho (MZSP); idem, 11.II.1968 (J. Halik leg.), 1 fêmea (MZSP); Parque Estadual da Cantareira, 20.X.1994 (Expedição MZUSP leg.), 1 fêmea (MZSP); Guarulhos, Sítio Bananal, 5.I.1959 (J. Halik leg.), 1 macho (USNM); São Paulo, VIII.1962 (sem coletor), 1 fêmea (MZSP); Salesópolis, Estação Biológica Boracéia, 21.I.1966 (Reichard leg.), 1 fêmea (MZSP); idem, 17.X.1960 (K. Lenko leg.), 1 macho (MZSP); idem, 14-18.XI.1973 (Expedição MZUSP leg.), 1 macho (MZSP); Caraguatatuba, Res. Fl., 22-1.V-VI.1962, 40m (Expedição Departamento de Zoologia leg.), 1 fêmea (MZSP); idem, 22-2.V-VII.1962, 40m (Expedição Departamento de Zoologia leg.), 1 macho (MZSP); idem, VIII.1965 (Expedição Departamento de Zoologia leg.), 2 fêmeas e 1 macho (MZSP); Cananéia, X.1934 (sem coletor), 1 fêmea (MNRJ); Pae. Mathias, X.1935 (J. Halik leg.), 4 fêmeas (USNM); idem, XI.1935 (J. Halik leg.), 2 machos (USNM); idem, 2.I.1960 (J. Halik leg.), 1 macho (USNM); Aquino, X.1922 (Fac. Medicina \& S. B. Pessôa leg.), 1 fêmea (MZSP); sem localidade, I.1934 (Coll. J. Guerin leg.), 1 macho (USNM); sem localidade,12.XII.1963 (J. Halik leg.), 1 fêmea (MZSP); sem localidade, data e coletor, 1 macho (NHMB). Santa Catarina: Hansa-Humboldt, sem data e coletor, 1 macho (NHMB); Timbó, I.1935 (Dirings leg.), 1 fêmea (MZSP); Rio Vermelho, XII.1948 (Dirings leg.), 1 fêmea (MZSP); idem, XI.1950 (Dirings leg.), 1 fêmea e 1 macho (MZSP); idem, XI.1952 (Dirings leg.), 1 macho (MZSP); idem, XII.1952 (Dirings leg.), 1 fêmea e 1 macho (MZSP); idem, XII.1953 (Dirings 
leg.), 1 macho (MZSP); idem, XII.1956 (Dirings leg.), 1 macho (MZSP); I.1961 (Dirings leg.), 1 macho (MZSP); Theresópolis, 1888 (sem coletor), 1 fêmea (USNM); idem, sem data e coletor, 2 fêmeas e 1 macho (USNM). Sem país e localidade, 1669 (B. de Piraley leg.), 1 macho (MZSP); sem localidade, data e coletor, 2 fêmeas (IRSNB); idem, 3 fêmeas e 1 macho (IRSNB); idem, 1 macho (NHRS); idem, 1 fêmea e 1 macho (NHMB); idem, 1 macho (MZSP); idem, 6 fêmeas e 4 machos (USNM).

Distribuição geográfica. Brasil (PA, MG, ES, RJ, SP e SC) e Argentina (Figs. 23 e 24).

Discussão. Semelhante a C. mera e C. variolosa quanto à coloração do pronoto e élitro e aspecto geral. Distingue-se de C. mera pelo padrão de pontuação, reticulado, e de ambas pela coloração da margem lateral, amarelada. Espécie representada pelos maiores exemplares. Saco interno com quatro escleritos (semelhantes aos observados em C. erythrodera). Bursa copulatrix com região posterior mais longa do que o observado para as outras espécies estudadas. 


\section{Cochabamba mera Bechyné, 1956}

(Figs. 7f, 10f, 12f, 14f, 23)

Cochabamba mera Bechyné, 1956: 261; Smith \& Lawrence, 1967: 92, 146 (revisão de tipos); Wilcox, 1972: 344 (catálogo). Holótipo: Mera, Ecuador/ Holotype (M), Cochabamba mera, J. Bechyné det., (NHMB), examinado.

DiAGNOSE.Antenas castanho-amareladas, sendo a porção basal esverdeada e o artículo apical castanho-escuro. Pronoto aproximadamente tão longo quanto largo, verde-claro. Élitros verde-claros, com pontuação formada por pontos moderadamente grossos e superficiais; presença de um par de plicas umerais, laterais. Pubescência da superfície ventral esbranquiçada.

Comprimento. 8-9 $\mathrm{mm}$.

Coloração geral (Fig. 12f) Esverdeada. Antenas castanho-amareladas, sendo os quatro artículos basais esverdeados, os quatro seguintes castanho-amarelados, os dois seguintes amarelos e o artículo apical castanho-escuro. Mesepisterno, mesepímero, metepisterno, metasterno e metepímero castanho-amarelados. Élitros verde-claros. Escutelo castanho-escuro. Pernas esverdeadas, com exceção dos fêmures, que são castanho-claros.

Pilosidade geral. Região dorsal com pilosidade esparsa, cerdas curtas a longas, esbranquiçadas. Cabeça com poucas cerdas, longas, esbranquiçadas, abaixo da linha dos olhos. Pilosidade longa, densa, esbranquiçada no mesosterno, mesepisterno, mesepímero, metepímero, metepisterno, ventritos e as margens laterais do metasterno.

Cabeça (Fig. 7f). Aspecto irregular e brihante. Pontuação logo acima dos calos antenais esparsa, média, na fêmea e densa, média, formando linhas que convergem em direção ao sulco interocular, no macho; pontuação na área fronto-clipeal, no macho, grossa, na fêmea, fina.

Tórax. Pronoto (Fig. 10f) com pontuação densa, pontos finos; presença de duas leves depressões ovóides medianas. Élitros (Fig. 14f) com pontuação densa, pontos moderadamente grossos; presença de cinco plicas umerais, laterais, pouco demarcadas.

Edeago. Não observado.

Genitália feminina. Não observada.

Material examinado. Panamá. Cocle: Cerro Peña, XI.1946 (N. I. H. Krauss leg.), 1 fêmea (USNM). EQUAdor.Pastaza: Mera, sem data e sem coletor, 1 macho (USNM), idem, 5 fêmeas (NHMB). Banos Eena[?], sem data (F. Campos R. leg.), 1 fêmea (USNM).

Distiribuição geográfica. Panamá e Equador (Fig. 23).

Discussão. Essa espécie pode ser facilmente diferenciada das outras espécies de Cochabamba que possuem padrão de coloração esverdeado por seus élitros com pontuação moderadamente grossa e pela presença de plicas umerais laterais. 


\section{Cochabamba polychroma Bechyné, 1956}

(Figs. 8a, 11a, 13a, 14g, 17j-1, 19e, 20e, 21e, 23, 24)

Cochabamba polychroma Bechyné, 1956: 260; Bechyné \& Bechyné, 1962: 25; Smith \& Lawrence, 1967: 107, 146 (revisão de tipos); Cabrera, 1999: 71 (redescrição); Wilcox, 1972: 344 (catálogo). Holótipo: Misiones, Argentina/ Holotype (M), Cochabamba polychroma, J. Bechyné det., 1954, (NHMB), examinado. Parátipos: Brasilien, Nova Teutonia, 3500m, Fritz Plaumann/ Allotype (F) Cochabamba polychroma, J. Bechyné det., 1954, (NHMB), examinado; BR-SP, Campos do Jordão, Eug. Lefevre - 1200m, 4-8 SET 953 - Trav. F, Pd. Pereira \& Medeiros/ P-Type, Cochabamba polychroma, J. Bechyné det., 1954, (MZSP), 6 exs., examinados.

Diagnose.Antenas castanhas, sendo os três articulos apicais esverdeados. Pronoto aproximadamente tão largo quanto longo, de verde-escuro a castanho-escuro. Élitros negros, pontuação formada por pontos finos e superficiais. Pubescência da superfície ventral amarelo-ouro.

Comprimento. 7-9 $\mathrm{mm}$.

Coloração geral (Fig. 12g). Castanha e esverdeada. Cabeça verde-clara. Antenas castanhas, com exceção dos três artículos apicais, que são esverdeados. Pronoto verde-escuro, com manchas castanho-escuras na porção central, ou então castanho-escuro. Prosterno verde. Metasterno castanho-escuro na região central e castanho-claro a castanho-amarelado lateralmente. Élitros e escutelo negros. Pernas castanhas, com exceção das tíbias, que são esverdeadas.

Pilosidade geral. Região dorsal com pilosidade esparsa, cerdas curtas a longas, esbranquiçadas. Cabeça com poucas cerdas, longas, esbranquiçadas, abaixo da linha dos olhos. Pilosidade longa, densa, esbranquiçada ou amarelo-clara a amarelo-ouro cobrindo totalmente o tegumento do mesosterno, mesepisterno, mesepímero, metepímero, metepisterno, ventritos e as margens laterais do metasterno.

Cabeça (Fig. 8a). Aspecto liso e brilhante. Pontuação esparsa, moderadamente grossa; presença de aberturas glandulares localizadas logo acima dos calos antenais.

Tórax. Pronoto (Fig. 11a) com pontuação densa, pontos finos; presença de dois pares de leves depressões ovóides medianas. Élitros com pontuação moderada, lisos.

Edeago. Lobo-médio (Figs. 17j, k) de ápice afilado, placa dorsal afilada. Saco interno com quatro escleritos (Fig. 17l) - descritos seguindo a sua localização no interior do lobo-médio -: o anterior denteado, um dos laterais alongado, de ápice afilado, o outro lateral côncavo, o mediano, pequeno, em forma de forquilha arredondada.

Genitália feminina. Spiculum ventrale (Fig. 21e) alongado, de comprimento semelhante ao comprimento da porção mediana da bursa copulatrix. Palpos vaginais (Fig. 
19e) de largura pouco variável ao longo de todo o comprimento, pouco mais longos do que o esternito VIII. Bursa copulatrix com região mediana fortemente esclerotizada, formando anel bem definido, com tegumento ornamentado com pequenas papilas. Espermateca (Fig. 20e) com porção basal fortemente côncava e ápice acuminado.

Material examinado. BRASIL. Minas Gerais: Mar de Espanha, 14.I.1909 (J. F. Zikán leg.), 1 fêmea (FIOC); Virgínia, Faz. Dos Campos, 19.XII.1917, 1500m (J. F. Zikán leg.), 1 fêmea (FIOC); Vila Monte Verde, 14.XI.1965 (J. Halik leg.), 1 macho (MZSP); idem, 28.XI.1965 (J. Halik leg.), 1 fêmea (MZSP); Passa Quatro, Faz. Dos Campos, 19.IV.1917 (J. F. Zikán leg.), 2 machos (FIOC); idem 28.IV.1919 (J. F. Zikán leg.), 1 macho (FIOC). São Paulo: Campos do Jordão, Eugênio Lefévre, 4-8.IX.1953, 1200m (Trav. F., Pd. Pereira \& Medeiros leg.), 8 fêmeas e 9 machos (MZSP), 2 fêmeas (NHMB); Pindamonhangaba, Eugênio Lefévre, 28-.IX-.1962 (K. Lenko leg.), fêmea (MZSP); idem, 26.X.1962 (K. Lenko leg.), 3 fêmeas e 2 machos (MZSP) e 4 fêmeas (DZUP); Barueri, XII.1958 (K. Lenko leg.), 1 fêmea (MZSP); idem, X.1962 (K. Lenko leg.), 1 fêmea (MZSP); idem, XII.1962 (K. Lenko leg.), 1 macho (MZSP); idem, I.1965 (K. Lenko leg.), 1 fêmea (MZSP); idem, X.1965 (K. Lenko leg.), 2 machos e 2 fêmeas (MZSP); idem, XI.1965 (K. Lenko leg.), 1 macho (MZSP); idem, XII.1965 (K. Lenko leg.), 7 fêmeas e 8 machos (MZSP); idem, I.1966 (K. Lenko leg.), 1 macho e 2 fêmeas (MZSP); idem, III.1966 (K. Lenko leg.), 1 macho (MZSP); idem, XII.1966 (K. Lenko leg.), 1 fêmea e 1 macho (MZSP); idem, 2.I.1967 (K. Lenko leg.), 1 fêmea e 2 machos (MZSP); idem, 4.I.1967 (K. Lenko leg.), 1 fêmea e 1 macho (MZSP); idem,19.II.1967 (K. Lenko leg.), 1 fêmea (MZSP); idem, 22.II.1967 (K. Lenko leg.), 1 fêmea (MZSP); São Paulo, Morumbi, 24.I.1943 (Dr. Nick leg.), 1 macho (MZSP); idem, 7.I.1945 (Dr. Nick leg.), 1 macho (MZSP); idem, II.1945 (Dirings leg.), 1 fêmea e 1 macho (MZSP); Osasco, 15.IV.1938 (F. Lane leg.), 1 fêmea (MZSP); São Bernardo, Represa Rio Grande, XII.1951 (B. Pohl leg.), 1 fêmea (MZSP). Santa Catarina: Nova Teutônia, XII.1952, 300-500m (Fritz Plaumann leg.), 1 fêmea (MZSP).

Distribuição geográfica. Brasil (MG, SP e SC), Argentina e Paraguai (Figs. 23 e 24).

Discussão. A coloração geral e o aspecto da superfície elitral combinados tornam o reconhecimento dessa espécie relativamente simples. 
Cochabamba rufolimbata (Baly, 1879) comb. nov.

(Fig. 12h, 23, 24)

Diabrotica rufolimbata Baly, 1879: 74; Baly, 1890: 71; Bechyné, 1956: 244 (checklist); Bechyné, 1958 (checklist); Bechyné \& Bechyné, 1962: 16 (checklist); Smith \& Lawrence, 1967: 92, 146 (revisão de tipos); Wilcox, 1972: 344 (catálogo). Lectótipo: F/ lectotype/ Rio de la Plata (BMNH), não examinado.

Diagnose.Antenas esverdeadas, sendo os dois artículos basais amarelados. Pronoto verde-claro. Élitros verde-claros, com margens laterais amareladas a alaranjadas, com pontuação formada por pontos finos e superficiais. Pubescência da superfície ventral moderadamente densa, esbranquiçada.

Comprimento. 6-9 $\mathrm{mm}$.

Coloração geral. (Fig. 12h) Esverdeada. Antenas esverdeadas, sendo os dois artículos basais amarelados. Mesepisterno, mesepímero, metepisterno, metasterno e metepímero esverdeados. Élitros verde-claros, com margens laterais amareladas a alaranjadas. Escutelo esverdeado. Pernas esverdeadas, com exceção dos tarsos, que são amarelados.

Pilosidade geral. Região dorsal com pilosidade esparsa, cerdas curtas, esbranquiçadas. Cabeça com poucas cerdas, longas, esbranquiçadas ou amareladas, abaixo da linha dos olhos. Região ventral com pilosidade moderadamente densa, cerdas de comprimento médio, esbranquiçadas. Pilosidade moderadamente densa, com cerdas de comprimento médio, esbranquiçadas no mesosterno, mesepisterno, mesepímero, metepímero, metepisterno, ventritos e as margens laterais do metasterno.

Cabeça. Aspecto liso e brihante. Pontuação fina, quase imperceptível.

Tórax. Pronoto com pontuação esparsa, pontos finos; tegumento liso, sem depressões. Élitros com pontuação densa, pontos moderadamente grossos.

Edeago. Tégmen em "Y". Lobo-médio com apíce acuminado. Placa dorsal afilada em relação ao ápice do lobo-médio. Saco interno com quatro escleritos - descritos seguindo a sua localização no interior do lobo-médio -: o anterior alongado de ápice expandido e denteado, um dos medianos, alongado, afilado, o outro alongado, expandido, de ápice arredondado, e o lateral recurvado.

Genitália feminina. Spiculum ventrale alongado, de comprimento ligeiramento maior do que o comprimento da porção mediana da bursa copulatrix, moderadamente esclerotizado. Palpos vaginais alongados, fortemente esclerotizados. Bursa copulatrix com região posterior longa, com região central fortemente esclerotizada, formando um anel bem definido, tegmento ornamentado com pequenas papilas. Espermateca com região basal fortemente côncava, ápice acuminado.

Material examinado. Brasil. Mato Grosso: Mata Verde, IV.1941 (Raimundo Luz leg.), 1 macho (MZSP); Riacho do Herval, Rio Paraná, sem data (Dirings leg.), 1 macho (MZSP); 
idem, XII.1951 (Dirings leg.), 1 fêmea (MZSP); idem, (B. Pohl leg.), 1 fêmea (MZSP); idem, XII.1952 (Dirings leg.), 1 fêmea e 2 machos (MZSP); idem, XII.1957 (Dirings leg.), 1 fêmea (MZSP); Rondonópolis, XI.1950 (Dirings leg.), 1 fêmea (MZSP); idem, XII.1950 (Dirings leg.), 1 fêmea (MZSP). Goiás: Aruanã, Rio Araguaia, V.1960 (Dirings leg.), 1 fêmea (MZSP); idem, I.1961 (Dirings leg.), 2 fêmeas (MZSP); idem, I-II.1961 (Dirings leg.), 1 macho (MZSP); idem, II.1961 (Dirings leg.), 1 fêmea (MZSP); idem, II.1962 (Dirings leg.), 5 fêmeas (MZSP); Pirenópolis, Pirapitinga, 20.VI.1942 (F. Lane leg.), 1 fêmea (MZSP). Minas Gerais: Pouso Alegre, IX.1962 (F. S. Pereira leg.), 1 macho (MZSP). Espírito Santo: Linhares, Parque Sooretama, 17-27.X.1962 (F. S. Pereira leg.), 8 fêmeas e 2 machos (MZSP). São Paulo: Itápolis, Faz. Palmeiras, X.1945 (F. Lane leg.), 2 fêmeas (MZSP); Nova Europa, Faz. Itaquerê, 24-31.VIII.1965 (Lenko \& Pereira leg.), 1 fêmea (MZSP); idem, XII.1964 (K. Lenko leg.), 2 fêmeas (MZSP); idem, 15.XII.1964 (K. Lenko leg.), 1 fêmea (MZSP); Rio Claro, I.1943 (Pe. Pereira leg.), 1 macho (MZSP).

Distiribuição geográfica. Brasil (MT, GO, MG, SP e ES) e Argentina (Fig. 23 e 24).

Discussão. A hipótese filogenética sugerida no presente trabalho indica que essa espécie faz parte do gênero Cochabamba, para o qual está sendo transferida. É muito semelhante, pelo padrão de coloração, à $C$. marginata, no entanto é facilmente diferenciada pela sua pontuação, formada por pontos moderadamente grossos. 


\section{Cochabamba rugulosa (Baly, 1886)}

(Figs. 8c, 11b, 13a, 14h, 23)

Diabrotica rugulosa Baly, 1886: 450; Gahan, 1891: 417, 464; Bechyné \& Bechyné, 1969: 56; Blackwelder, 1946: 685 (checklist). Lectótipo: Type/ E. Ecuador/ Diabrotica rugulosa Baly E. Ecuador/ Baly Coll, não localizado.

Cochabamba rugulosa; Bechyné, 1956: 261; Smith \& Lawrence, 1967: 117, 146 (revisão de tipos); Wilcox, 1972: 344 (catálogo).

Diagnose. Antenas esverdeadas, sendo os artículos apicais castanho-amarelados. Pronoto aproximadamente tão longo quanto largo, castanho-escuro a negro. Élitros negros, com manchas verde-claras arredondadas, adjacentes ao ápice; presença de plicas umerais, laterais, pontuação fina e superficial, pouco conspícua. Pubescência da superfície ventral de amarelo-clara a amarelo-ouro.

Comprimento. 8-9 $\mathrm{mm}$.

Coloração geral (Fig. 13a) Castanho-escura a negra. Antenas esverdeadas, sendo os artículos VIII-XI castanho-amarelados. Mesepímero amarelado. Metepisterno castanho-amarelado. Metasterno castanho-escuro na região central e castanho-claro a castanho-amarelado lateralmente. Metepímero amarelado. Élitros negros; presença de manchas de verde-claras, arredondadas, adjacentes à margem apical. Escutelo negro. Pernas castanhas, com exceção dos trocânteres, que são amarelo-claros e dos fêmures, que são verde-escuros.

Pilosidade geral. Região dorsal com pilosidade esparsa, cerdas curtas a longas, esbranquiçadas. Cabeça com poucas cerdas, longas, esbranquiçadas, abaixo da linha dos olhos. Pilosidade longa, densa, de amarelo-clara a amarelo-ouro cobrindo totalmente o tegumento do mesosterno, mesepisterno, mesepímero, metepímero, metepisterno, ventritos e as margens laterais do metasterno.

Cabeça (Fig. 8c). Aspecto liso e brilhante. Pontuação esparsa, fina, presença de aberturas glandulares localizadas logo acima dos calos antenais.

Tórax. Pronoto (Fig. 11b) com pontuação densa, pontos finos, presença de duas depressões circulares medianas bem demarcadas. Élitros (Fig. 14h) com pontuação densa, pontos moderadamente grossos; presença de seis plicas umerais, laterais.

Edeago. Não observado.

Genitália feminina. Não observada.

Material examinado. Peru: Pasco: Oxapampa, sem data e coletor, 1 fêmea (NHMB). Sem país, localidade, data e coletor, 1 fêmea (NHMB).

Distribuição geográfica. Equador e Peru (Fig. 23).

Discussão. Espécie facilmente reconhecida pelos élitros negros com manchas esverdeadas presentes no ápice. 


\section{Cochabamba variolosa (Jacoby, 1878)}

(Figs. 8c, 11c, 13b, 14i, 23)

Diabrotica variolosa Jacoby, 1878: 151; Gahan, 1891: 524; Bowditch, 1911: 10; Blackwelder, 1946: 686 (checklist). Holótipo: Ecuad/ Type/ 1st Jacoby Coll./ Type 17707 (MCZC), fotos disponíveis no sítio da instituição examinadas.

Cochabamba variolosa; Bechyné, 1955: 6; Smith \& Lawrence, 1967: 139, 146 (revisão de tipos).

Diagnose Antenas castanho-amareladas, com artículos basais esverdeados. Pronoto aproximadamente tão longo quanto largo, verde-claro a verde-escuro. Élitros verde-claros, com pontuação reticulada, formada por pontos grosseiros e profundos. Pubescência da supefície ventral amarelo-ouro.

Comprimento. $7-8 \mathrm{~mm}$.

Coloração geral. (Fig. 13b) Castanho-escura. Antenas castanho-amareladas, sendo os três artículos basais esverdeados. Pronoto verde-escuro. Prosterno e mesosterno esverdeados. Élitros verdes-claros. Escutelo castanho-escuro avermelhado a negro. Pernas castanhas, com exceção dos fêmures e coxas, que são esverdeados. Ventrito V e últimos tergitos castanho-escuros avermelhados na metade posterior.

Pilosidade geral. Região dorsal com pilosidade esparsa, cerdas curtas a longas, esbranquiçadas. Cabeça com poucas cerdas, longas, esbranquiçadas, abaixo da linha dos olhos. Pilosidade longa, densa, amarelo-ouro cobrindo totalmente o tegumento do mesosterno, mesepisterno, mesepímero, metepímero, metepisterno, ventritos e as margens laterais do metasterno.

Cabeça (Fig. 8c). Aspecto liso e brilhante. Pontuação esparsa, fina, presença de aberturas glandulares localizadas logo acima dos calos antenais.

Tórax. Pronoto com pontuação esparsa, pontos finos; presença de duas leves depressões circulares medianas (Fig. 11c). Élitros com pontuação reticulada.

Edeago. Não observado.

Genitália feminina. Não observada.

Material examinado. Peru. Lambayeque: Olmos, sem data (sem coletor), 1 macho (NHMB).

Distribuição geográfica. Equador e Peru (Fig. 23).

Discussão. Por seu aspecto geral, pode ser confundida com C. marginata. Um exame mais cuidadoso revela a sua identidade através da coloração geral, que é mais clara. 


\section{Cochabamba sp. nov.}

(Figs. 8d, 11d, 13c, 14j, 18e, 19f, 20f, 21f, 23)

Holótipo: Peru, Torentoy Canyon (Base Machu Picchu), VI-VII.1964, 2000m (B. Malking leg.), fêmea (MZSP). Parátipo: Peru, Macchu Picchu, 29. I .952, 2000m, Coll. F. Monros/ F. Monros Collection, 1959, macho (USNM).

Diagnose. Antenas amareladas, sendo os artículos apicais castanhos. Pronoto aproximadamente tão longo quanto largo, negro. Élitros negros, na metade basal, avermelhados na região central e amarelados, no terço apical, presença de plicas umerais, pontuação formada por pontos moderademtne grossos e profundos. Pubescência da superfície ventral amarelo-ouro.

Comprimento. $8-9 \mathrm{~mm}$.

Coloração geral (Fig. 13c) Negra. Antenas amareladas, sendo os cinco artículos apicais castanhos. Clípeo e peças bucais negras. Élitros negros na metade basal, avermelhados na região central e amarelados no terço apical. Escutelo negro. Pernas amareladas. Ventritos verde-claros.

Pilosidade geral. Região dorsal com pilosidade esparsa, cerdas curtas a longas, esbranquiçadas. Cabeça com poucas cerdas, longas, esbranquiçadas, abaixo da linha dos olhos. Região ventral com pilosidade densa, cerdas escuras. Pilosidade longa, densa, esbranquiçada ou amarelo-ouro cobrindo totalmente o tegumento do mesosterno, mesepisterno, mesepímero, metepímero, metepisterno, ventritos e margens as laterais do metasterno.

Cabeça (Fig. 8d). Aspecto liso e brilhante. Pontuação esparsa, moderadamente grossa, presença de aberturas glandulares localizadas logo acima dos calos antenais.

Tórax. Pronoto (Fig. 11d) aproximadamente tão longo quanto largo, pontuação densa, pontos moderadamente grossos; presença de duas leves depressões circulares medianas. Élitros (Fig. 14j) com pontuação densa, pontos moderadamente grossos, presença de seis plicas umerais.

Edeago. Não observado.

Genitália feminina. Spiculum ventrale (Fig. 21f) alongado, de comprimento semelhante ao comprimento da porção mediana da bursa copulatrix, fortemente esclerotizado. Palpos vaginais (Fig. 19f) alongados, de comprimento igual a cerca da metade do comprimento do spiculum ventrale, fortemente esclerotizados. Bursa copulatrix (Fig. 18e) com porção central moderadamente esclerotizada, formando um anel bem definido, com tegumento ornamentado com pequenas papilas. Espermateca (Fig. 20f) com porção basal moderadamente côncava e ápice acuminado.

Distribuição geográfica. Peru (Fig. 23).

Discussão. A coloração elitral é a característica mais facilmente utilizada para identificação dessa espécie. 


\section{Espécie excluída de Cochabamba}

\section{Paranapiacaba volxemi (Baly, 1889) comb. reval.}

(Figs. 8e, 11e, 13f, 14k, 17m-o, 18f, 19g, 20g, 21g, 23, 24)

Diabrotica volxemi Baly, 1889: 253; Baly 1891: 417, 440. Lectótipo: Type/ Diabrotica volxemi Baly Brazil/ Baly Coll. (BMNH), examinado. Paralectótipo: Col. Camille Van Volxem./ volxemi/ Baly Coll. (BMNH), examinado.

Synbrotica volxemi; Bechyné, 1956: 275.

Paranapiacaba volxemi; Bechyné, 1958: 562; Bechyné \& Bechyné, 1962: 46, 48; Smith \& Lawrence, 1967: 143, 151 (revisão de tipos); Wilcox, 1972: 348 (catálogo). comb. reval.

Cochabamba volxemi; Moura, 2003: 645.

Diagnose. Antenas negras, o antenômero III duas vezes mais longo do que o antenômero II. Pronoto mais largo do que longo, negro. Élitros negros, com oito pares de máculas arredondadas, amareladas, alinhados longitudinalmente. Pubescência da superfície ventral amarelo-clara.

Comprimento. $5-7 \mathrm{~mm}$.

Coloração geral (Fig. 13f) Negra, com brilho metálico esverdeado. Élitros negros, presença de quatro pares de máculas amareladas e arredondadas em cada élitro, de tamanho variável, dispostas em fileira alinhada longitudinalmente - pode haver fusão parcial de algumas das máculas, mais frequentemente observável no par mais apical.

Pilosidade geral. Região dorsal com pilosidade esparsa, cerdas curtas a longas, esbranquiçadas. Cabeça com cerdas numerosas, longas, esbranquiçadas ou amareladas, abaixo da linha dos olhos. Região ventral com pilosidade densa, cerdas escuras. Pilosidade longa, densa, esbranquiçada ou amarelo-clara cobrindo totalmente o tegumento do mesosterno, mesepisterno, mesepímero, metepímero, metepisterno, ventritos e as margens laterais do metasterno.

Cabeça (Fig. 8e). Aspecto irregular e brilhante. Pontuação esparsa, concentrada logo acima dos calos antenais, esparsa e média, na fêmea; densa, média, formando linhas que convergem em direção à sutura coronal, no macho. Pontação da área fronto-clipeal, densa, grossa, no macho. Olhos médios (ocupam cerca de metade da largura total da cabeça em vista dorsal), linhas orbitais distantes da margem do olho na porção próxima ao vértice. Antenas (Fig. 9f) iguais em ambos os sexos, antenômero II de comprimento igual a cerca da metade do comprimento dos artículos seguintes.

Tórax. Pronoto (Fig. 11e) mais largo do que longo (a largura é igual a 1,5 vez o comprimento), pontuação densa, pontos grossos; presença de duas leves depressões circulares medianas. Élitros com pontuação densa, pontos grossos, semelhante à pontuação do pronoto. 
Edeago. Tégmen em forma de "Y". Lobo-médio (Figs. 17m, n) com placa dorsal com ápice moderadamente largo. Saco interno com três escleritos (Fig. 17o) - descritos seguindo a sua localização no interior do lobo-médio -: o apical denteado na porção anterior e alongado na região basal, o mediano alongado, estreito e de ápice convexo, o lateral com porção anterior denteada e porção posterior afilada e bífida.

Genitália feminina. Spiculum ventrale (Fig. 21g) alongado, de comprimento cerca de três vezes maior do que o comprimento do esternito VIII. Palpos vaginais (Fig. 19g) fortemente esclerotizados, com porção mediana pouco esclerotizada e ovóide, alongados. Bursa copulatrix (Fig. 18f) com região central relativamente curta, região mediana, fortemente esclerotizada, formando uma placa ventral subtrapezoidal. Espermateca (Fig. 20g) moderadamente larga, moderadamente côncava na região basal, de ápice acuminado.

Material examinado. Brasil. São Paulo: Campos do Jordão, III.1905 (Luederwaldt leg.), 1 macho (MZSP); idem, XII.1905 (Luederwaldt leg.), 7 machos (MZSP); idem, III.1906 (Luederwaldt leg.), 1 macho (MZSP); idem, 26.XII.1944 (F. Lane leg.), 2 machos e 2 fêmeas (MZSP); idem, X.1949 (J. Halik leg.), 2 machos (MZSP); idem, X.1959 (J. Halik leg.), 4 machos (MZSP); idem, XI.1966 (J. Halik leg.), 1 fêmea (MZSP); idem, 1966 (J. Halik leg.), 6 machos e 4 fêmeas (MZSP).

Distribuição geográfica. Brasil (SP) (Fig. 23).

Discussão. A revalidação da combinação é proposta considerando os resultados obtidos na análise cladística do gênero Cochabamba, cujas topologias (Figs. 1 e 3) indicam uma afinidade com a espécie Paranapiacaba teinturieri. A presença, nessa espécie, do caráter diagnóstico de Cochabamba, pilosidade muito densa que encobre completamente o metepisterno e escleritos vizinhos, é considerada resultado de convergência evolutiva e não é suficiente para manter o táxon nesse gênero. A comparação com a espécie-tipo de Paranapiacaba, P. decemverrucata, confirmou diversas evidências morfológicas da sua afinidade com $P$. volxemi. 


\section{Conclusões}

A análise cladística apresentada, baseada em caracteres morfológicos de indivíduos adultos, indica que o gênero Cochabamba Bechyné, 1955, como definido até então, formava um agrupamento merofilético. A monofilia do gênero é, no entanto, recuperada com a remoção de C. volxemi, espécie que deve ser incluída no gênero Paranapiacaba Bechyné, 1958, e com a inclusão de Diabrotica rufolimbata, epécie utilizada como grupo-externo. O gênero Cochabamba é, aqui, definido por quatro sinapomorfias: olhos grandes, antenômero III mais curto do que o antenômero $\mathrm{V}$, pronoto aproximadamente tão largo quanto longo e saco interno do lobo-médio com quatro escleritos. Caracteres referentes à genitália e à coloração mostraram-se importantes na definição dos agrupamentos internos e dos terminais, além de auxiliarem a identificação em nível específico.

Os caracteres citados na descrição original como diagnósticos para Cochabamba não representam sinapomorfias para o clado que o define, sendo considerados resultado de convergência evolutiva. Um dos agrupamentos internos, Diabrotica rufolimbata + Cochabamba mera, tem posicionamento instável nas topologias observadas, de forma que será mais prudente incluir outros terminais, que representem melhor a diversidade encontrada nos gêneros amostrados para o grupo-externo, para confirmar seu posicionamento em Cochabamba, assim como definir melhor seus agrupamentos internos.

O gênero Cochabamba como aqui definido está formado por 11 espécies, sendo 9 anteriormente incluídas no gênero, além de uma espécie nova e uma espécie transferida de Diabrotica. 


\section{Referências bibliográficas}

Amorim, D. D. S. 1982. Classificação por sequenciação: uma proposta para a denominação dos ramos retardados. Revista Brasileira de Zoologia, 1 (1): 1-9.

Areekul, B. \& Quicke, D. L. J. 2006. The use of colour characters in phylogenetic reconstruction. Biological Journal of the Linnean Society, 88: 193-202.

Arnett-Jr., R. H.; Samuelson, G. A. \& Nishida, G. M. 1993. The insect and spider collections of the world. Sandhill Crane Press, Gainesville.

Baly, J. S. 1879. Descriptions of new Genera and Species of Galerucinae. The Annals 6 Magazine of Natural History, 5 (III): 73-84.

Baly, J. S. 1886. Descriptions of uncharacterized species of Diabrotica. Transactions of the Entomological Society of London, 443-445.

Baly, J. S. 1889. Diagnoses of uncharacterized species of Diabrotica. The Entomologist's Monthly Magazine, London, 35: 251-254.

Baly, J. S. 1890. On the South American species of Diabrotica. Part I. The Transacions of the Entomological Society, 38 (1): 1-86.

Bechyné, J. 1955a. Les Chrysomeloidea de Cayenne captures par le Dr. E. Abonnenc (Col. Phytophaga). Bulletin mensuel de la Société Linnéenne de Lyon, 24: 139-142.

Bechyné, J. 1955b. Quatrième note sur les Chrysomeloidea néotropicaux des collections de l'Institut Royal des Sciences Naturelles de Belgique. Bulletin de l'Institut Royal des Sciences Naturelles de Belgique, 31 (74): 1-12.

Bechyné, J. 1956. Reise des Herrn G. Frey in Südamerika: Galerucidae (Col. Phytophaga). Entomologische Arbeiten aus dem Museum Georg Frey, 7 (1): 241-358.

Bechyné, J. 1958. Notizen zu den neotropischen Chrysomeloidea (Col. Phytophaga). Entomologische Arbeiten, Tutzing, 9 (2): 478-706.

Bechyné, J. \& Bechyné, S. B. D. 1961. Insecta Amapaensia: Chrysomeloidea (Col. Phytoph.). Studia Entomologica, Petropolis, 4: 409-428.

Bechyné, J. \& Bechyné, S. B. D. 1962. Liste der bisher in Rio Grande do Sul gefundenen Galeruciden. Pesquisas (Zool.), 6 (15): 1-63.

Blackwelder, R. E. 1946. Check-list of the Coleopterous insects of Mexico, Central America, the West Indies, and South America. Part 4. Bulletin of the United States National Museum, Washington, 185: 551-763. 
Borowiec, L. 1995. Tribal classification of the cassiodoid Hispinae, 541-558. Muzeum i Instytut Zoologii PAN, Warszawa.

Bowditch, F. C. 1911. Notes on Diabrotica and descriptions of new species. The Canadian Entomologist, 43 (3): 89-97.

Bünnige, M.; Hilker, M. \& Dobler, S. 2008. Convergent evolution of chemical defence in Galerucine larvae. Biological Journal of the Linnean Society, 93: 165-175.

Cabrera, N. C. 1999. Redescripción de Cochabamba polychroma Bechyné y C. chacoensis (Bowditch) (Coleoptera: Chrysomelidae: Galerucinae). Neotropica (La Plata), 45 (113-114): 69-75.

Cabrera, N. C. \& Walsh, G. C. 2004. Diabrotica calchaqui, a new species of Luperini (Coleoptera: Chrysomelidae: Galerucinae), from Argentina. Annals of the Entomological Society of America, 97 (5): 889-897.

Cabrera, N. C.; Sosa Gómez, D. R. \& Micheli, A. 2008. Morphological and molecular characterization of a new species of. Zootaxa, 1922: $33-46$.

Christensen, J. R. 1943. Estudio sobre el genero Diabrotica Chev. en la Argentina. Revista de la Facultad de Agronomía y Veterinaria de Buenos Aires, 10: 464-516.

Costa, C. 1999. Coleoptera, 113-122. (FAPESP), Fundação De Amparo À Pesquisa Do Estado De São Paulo, São Paulo.

Costa, C.; Vanin, S. A. \& Casari-Chen, S. A. 1988. Larvas de Coleoptera do Brasil. Universidade de São Paulo, São Paulo.

Costa Lima, A. 1931. Insetos do Brasil, Coleópteros.

Crowson, R. A. 1967. The natural classification of the families of Coleoptera. E. W. Classey, Middlesex.

Crowson, R. A. 1981. The biology of Coleoptera. Academic Press, London.

Crowson, R. A. \& Crowson, E. A. 1996. The phylogenetic relations of Galerucinae-Alticinae, 97-118. Academic Publishing, Amsterdam.

Duckett, C. N. 1995. Variation in reproductive structures. Chrysomela Newsletter, 20: $4-5$.

Duckett, C. N.; Gillespie, J. J. \& Kjer, K. M. 2004. Relationships among the subfamilies of Chrysomelidae inferred from small subunit ribosomal DNA and morphology, with special emphasis on the relationship among the fle beetles and the Galerucinae. The Hague, Neetherlands. 
Farrell, B. D. 1998. "Inordinate fondness"explained: why are there so many beetles? Science, 281: 555-559.

Farrell, B. D. \& Sequeira, A. S. 2004. Evolutionary rates in the adaptive radiation of beetles on plants. Evolution; international journal of organic evolution, 58 (9): 1984-2001.

Farris, J. S. 1969. A sucessive approximations approach to character weighting. Systematic Zoology, 18: 374-385.

Flowers, W. R. \& Eberhard, W. G. 2006. Fitting together: copulatory linking in some Neotropical Chrysomeloidea. Revista de Biologia Tropical, 54 (3): 829-842.

Gahan, C. J. 1891. On the South American species of Diabrotica. Part II. Transactions of the Royal Entomological Society of London, 39 (3): 415-472.

Gillespie, J. J.; Kjer, K. M.; Duckett, C. N. \& Tallamy, D. W. 2003. Convergent evolution of cucurbitacin feeding in spatially isolated rootworm taxa (Coleoptera: Chrysomelidae; Galerucinae, Luperini). Molecular Phylogenetics and Evolution, 29: 161-175.

Gillespie, J. J.; Kjer, K. M.; Riley, E. G. \& Tallamy, D. W. 2004. The evolution of cucurbitacin pharmacophagy in rootworms: insight from Luperini paraphyly, 33-57. Kluwer Academic Publishers, Boston.

Gillespie, J. J.; Tallamy, D. W.; Riley, E. G. \& Cognato, A. I. 2008. Molecular phylogeny of rootworms and related galerucine beetles (Coleoptera: Chrysomelidae). Zoologica Scripta, 37 (2): 195-222.

Goloboff, P. A.; Farris, J. S. \& Nixon, K. C. 2008. TNT, a free program for phylogenetic analysis. Cladistics, 24: 774-786.

Gómez-Zurita, J.; Hunt, T. \& Vogler, A. P. 2008. Multilocus ribosomal RNA phylogeny of the leaf beetles (Chrysomelidae). Cladistics, 24: 34-50.

Harold, E. V. 1875. Diagnosen neuer Arten. Coleopterologische Hefte, 13: 58-181.

Jacoby, M. 1878. Description of new species of phytophagous Coleoptera from Central and South America. Proceedings Of The Zoological Society Of London, 46 (1): 982-996.

Kim, S. J.; Kjer, K. M. \& Duckett, C. N. 2003. Comparison between molecular and morphological-based phylogenies of galerucine/alticine leaf beetles (Coleoptera : Chrysomelidae). Insect Systematics \&5 Evolution, 34 (1): 53-64.

Kinoshita, S.; Yoshioka, S. \& Miyazaki, J. 2008. Physics of structural colors. Reports on Progress in Physics, 71 (7): 1-30. 
Konstantinov, A. S. 1998. On the structure and function of the female genitalia in flea beetles (Coleoptera: Chrysomelidae: Alticinae). Proceedings of the Entomological Society of Washington, 100 (2): 353-360.

Konstantinov, A. S. 2002. New data on the structure of the female genitalia of flea beetles (Coleoptera: Chrysomelidae). Proceedings of the Entomological Society of Washington, 104 (1): 237-239.

Krysan, J. L. \& Smith, R. F. 1987. Systematics of the virgifera species group of Diabrotica (Coleoptera: Chrysomelidae: Galerucinae). Entomography, 5: 375-484.

Lawrence, J. F. \& Newton, A. F. 1995. Families and subfamilies of Coleoptera (with selected genera, notes, references and data on family-group names), 779-1006. Muzeum i Instytut Zoologii PAN, Warszawa.

Lawson, A. F. 1987. Chrysomelidae (Chrysomeloidea). Kendall/Hunt Publishing Company, Dubuque.

LeSage, L. 1986. A taxonomic monograph of the nearctic galerucine genus Ophraella Wilcox (Coleoptera: Chrysomelidae). Memoirs of the Entomological Society of Canada, 118 (133): 1-75.

Leschen, R. A. B.; Beutel, R. G. \& Lawrence, J. F. (eds.). 2010. Handbook of Zoology, Vol. 2: Coleoptera, Beeles: Morphology and Systematics. De Gruyter, Berlin, $2^{\mathrm{a}}$ ed.

Lindorth, C. H. \& Palmen, E. 1956. Coleoptera. Ejnar Munksgaard, Copenhagen.

Lingafelter, S. W. \& Konstantinov, A. S. 1999. The monophyly and relative rank of alticine and galerucine leaf beetles: a cladistic analysis using adult morphological characters (Coleoptera: Chrysomelidae). Entomologica Scandinavica, 30 (4): 397-416.

Maddison, W. P. \& Maddison, D. R. 2010. Mesquite: a modular system for evolutionary analysis. Versão 2.73 .

Mann, J. S. \& Crowson, R. A. 1996. Internal sac structure and phylogeny of Chrysomelidae, 444. Academic Publishing, Amsterdam.

Mickoleit, G. 1973. Über den ovipositor der Neuropteroidea und Coleoptera und seine phylogenetische Bedeutung. Zeitschrift für Morphologie der Tiere, 74 (1): 37-64.

Moura, L. D. A. 1998. Revisão do gênero Neolochmaea (Coleoptera, Chrysomelidae, Galerucinae, Galerucini). Iheringia, Série Zoologia, 85: 169-188.

Moura, L. D. A. 2003. Nova espécie de Zischkaita Bechyné e notas taxonômicas em Galerucini (Coleoptera, Chrysomelidae, Galerucinae). Revista Brasileira de Zoologia, 20 (3): 643-645. 
Moura, L. D. A. 2009. Morfologia comparada da genitália masculina de Galerucini (Coleoptera, Chrysomelidae, Galerucinae). Revista Brasileira de Entomologia, 53 (1): $15-22$.

Muir, F. 1918. Notes on the ontogeny and morphology of the male genital tube in Coleoptera. Transactions of the Entomological Society of London, 223-229.

Newman, E. 1835. Attempted division of British insects into natural orders. Entomological Magazine, 2: 379-431.

Nixon, K. C. 1999. Winclada (BETA) ver 0.9.9.

Nixon, K. C. \& Carpenter, J. M. 1993. On outgroups. Cladistics, 9: 413-426.

Powel, E. F. 1941. Relationships within the family Chrysomelidae (Coleoptera) as indicated by the male genitalia of certain species. American Midland Naturalist, 25 (1): 148-195.

Reid, C. A. M. 1988. Bellaltica Reid, a new genus of Alticinae (Coleoptera: Chrysomelidae) from south-west Western Australia. The Coleopterists Bulletin, 42 (3): 219-231.

Reid, C. A. M. 1995. A cladistic analysis of subfamilial relationships in the Chrysomelidae sensu lato (Chrysomeloidea). Muzeum i Instytut Zoologii PAN, Warszawa.

Reid, C. A. M. 2000. Spylopirinae Chapuis: a new subfamily in the Chrysomelidae and its systematic placement (Coleoptera). Invertebrate Taxonomy, 14: 837-862.

Riley, E. G.; Clark, S. M.; Flowers, W. R. \& Gilbert, A. J. 2002. Chrysomelidae Latreille 1802, 617-691. CRC Press.

Seago, A. E.; Brady, P.; Vigneron, J.-P. \& Schultz, T. D. 2009. Gold bugs and beyond: a review of iridescence and structural colour mechanisms in beetles (Coleoptera). Journal of the Royal Society, Interface, 165-84.

Seeno, T. \& Wilcox, J. A. 1982. Leaf Beetle Genera (Coleoptera: Chrysomelidae). Entomography, 1: 1-221.

Sereno, P. C. 2007. Logical basis for morphological characters in phylogenetics. Cladistics, 23: $565-587$.

Sharp, D. \& Muir, F. 1912. The comparative anatomy of the male genital tube in Coleoptera. Transactions of the Entomological Society of London, 477-642. 
Smith, E. H. 1979. Techniques for the dissection and mounting of the male (aedeagus) and female (spermatheca) genitalia of the Chrysomelidae (Coleoptera). The Coleopterists Bulletin, 33 (1): 93-103.

Smith, R. F. \& Lawrence, J. F. 1967. Clarification of the status of the type specimens of Diabroticites. University of California Press, 45.

Snodgrass, R. E. 1935. Principles of insect morphology. McGraw-Hill, New York.

Spilman, T. J. 1971. The longitudinal lines on beetle elytra : a definition of stria. The Coleopterists Bulletin, 25 (4): 121-122.

Staines, C. L. 2002. The New World tribes and genera of hispines (Coleoptera: Chrysomelidae: Cassidinae). Proceedings of the Entomological Society of Washington, 104: $721-784$.

Stapel, H.; Misof, B. \& Wagner, T. 2008. A molecular and morphological phylogenetic analysis of Afrotropical Monolepta species and related Galerucinae (Coleoptera: Chrysomelidae). Arthropod Systematics 86 Phylogeny, 66 (1): 3-17.

Swigonová, Z. \& Kjer, K. M. 2004. Phylogeny and host-plant association in the leaf beetle genus Trirhabda LeConte (Coleoptera: Chrysomelidae). Molecular Phylogenetics and Evolution, 32: 358-374.

Verma, K. K. 1969. Functional and developmental anatomy of the reproductive organs in the male of Galerucella birmanica Jac. (Coleoptera, Phytophaga, Chrysomelidae). Analles des Sciences Naturelles, Zoologie, Paris, 12 (XI): 139-234.

Verma, K. K. 1996. Inter-subfamily relations among Chrysomelidae (Coleoptera) as suggested by organization of the male genital system, 444. Academic Publishing, Amsterdam.

Wagner, T. \& Kurtscheid, A. 2005. Revision of Candezea Chapuis, 1879 (Coleoptera, Chrysomelidae, Galerucinae) from continental Africa. Journal of Natural History, 39 (28): 2591-2641.

Weise. 1924. Chrysomelidae: Galerucinae. Pars 78. W. Junk, Berlim.

Wilcox, J. A. 1965. A synopsis of the North American Galerucinae (Coleoptera: Chrysomelidae). Bulletin of the New York State Museum and Science Service, 400: $1-226$.

Wilcox, J. A. 1972. Chrysomelidae: Galerucinae, Luperini: Aulacophorina, Diabroticina, 221-431. Netherlands. 


\section{Apêndices}

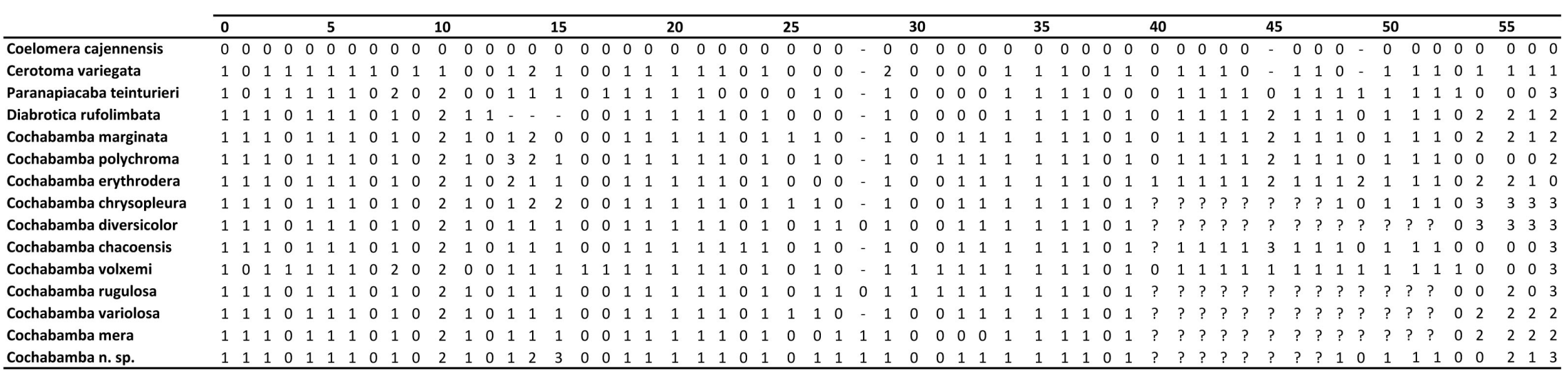

Tabela 1: Matriz de dados morfológicos. (0): estados plesiomórficos; (1-3): estados apomórficos; (-): inaplicáveis; (?): não observados. 


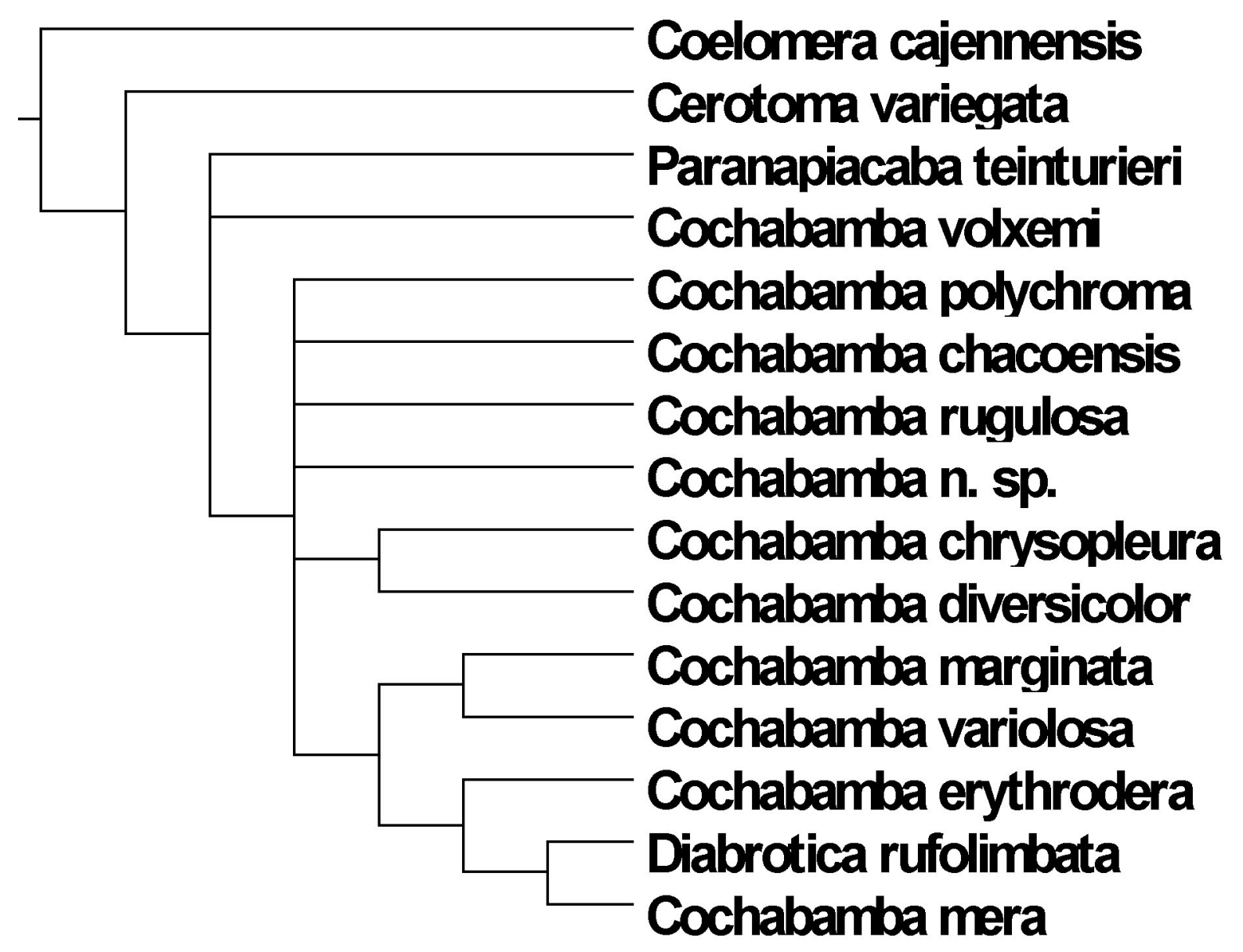

Figura 1: Cladograma de consenso obtido a partir das árvores mais parcimoniosas encontradas na busca exaustiva com pesos iguais $(C=108$ passos; $\mathrm{IC}=71$; $\mathrm{IR}=53)$. 

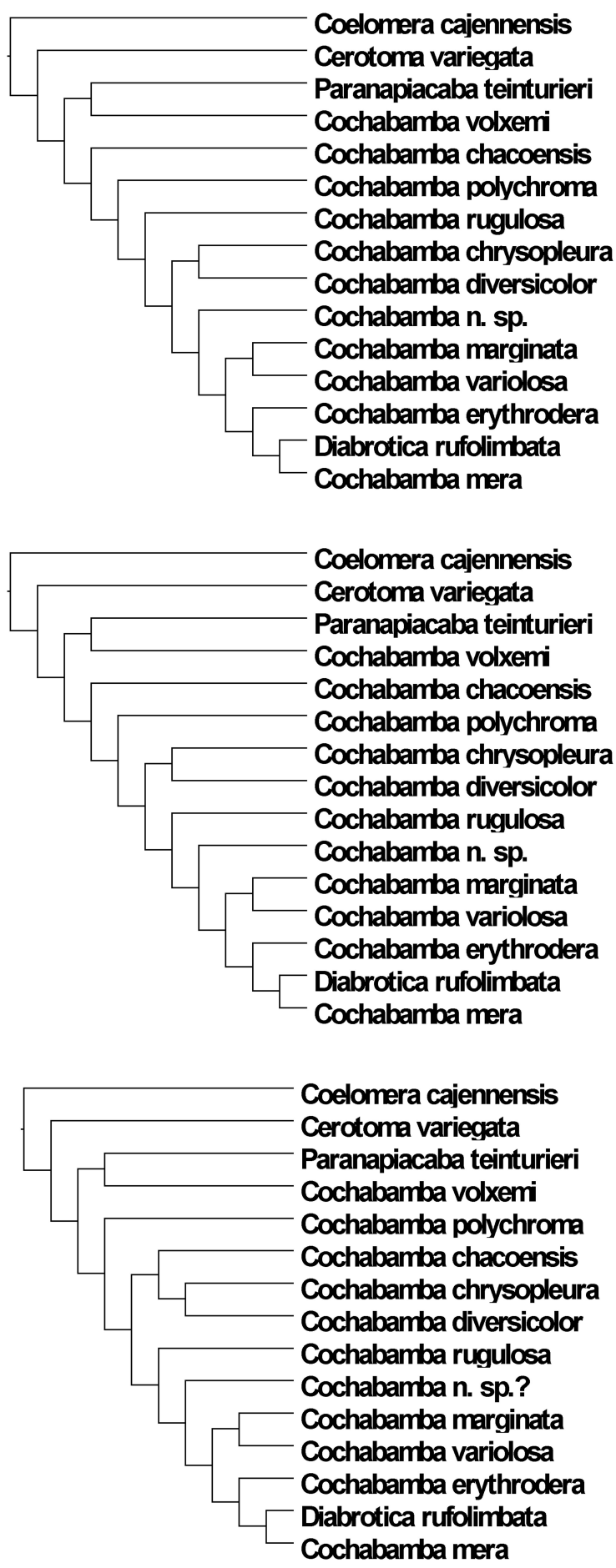

Figura 2: Cladogramas resultantes da busca exaustiva com pesagem sucessiva dos caracteres $(\mathrm{C}=102$ passos; $\mathrm{IC}=75 ; \mathrm{IR}=62)$. 


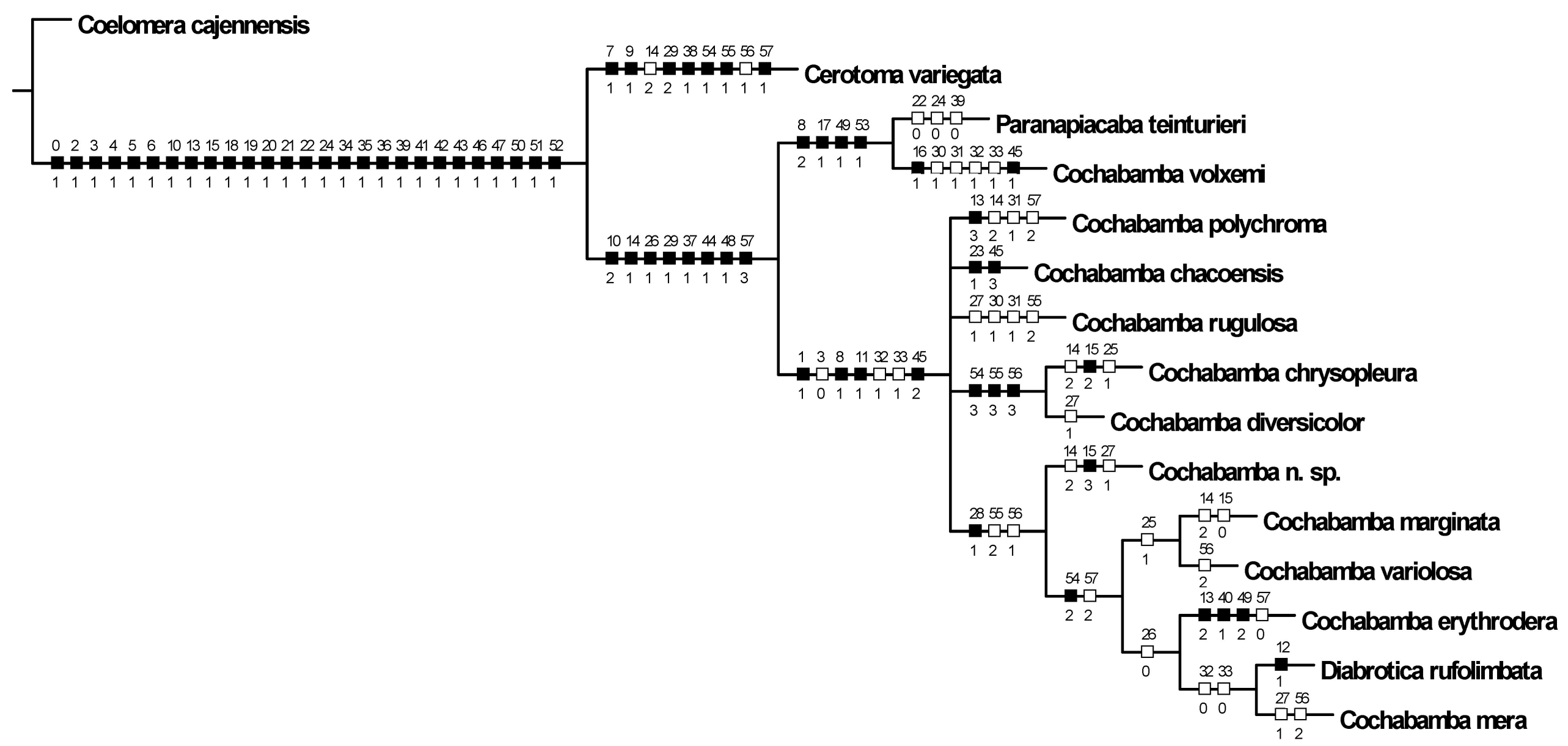

Figura 3: Cladograma de consenso obtido a partir das árvores mais parcimoniosas encontradas após busca exaustiva com pesagem sucessiva dos caracteres $(\mathrm{C}=103 ; \mathrm{IC}=74 ; \mathrm{IR}=60)$. 


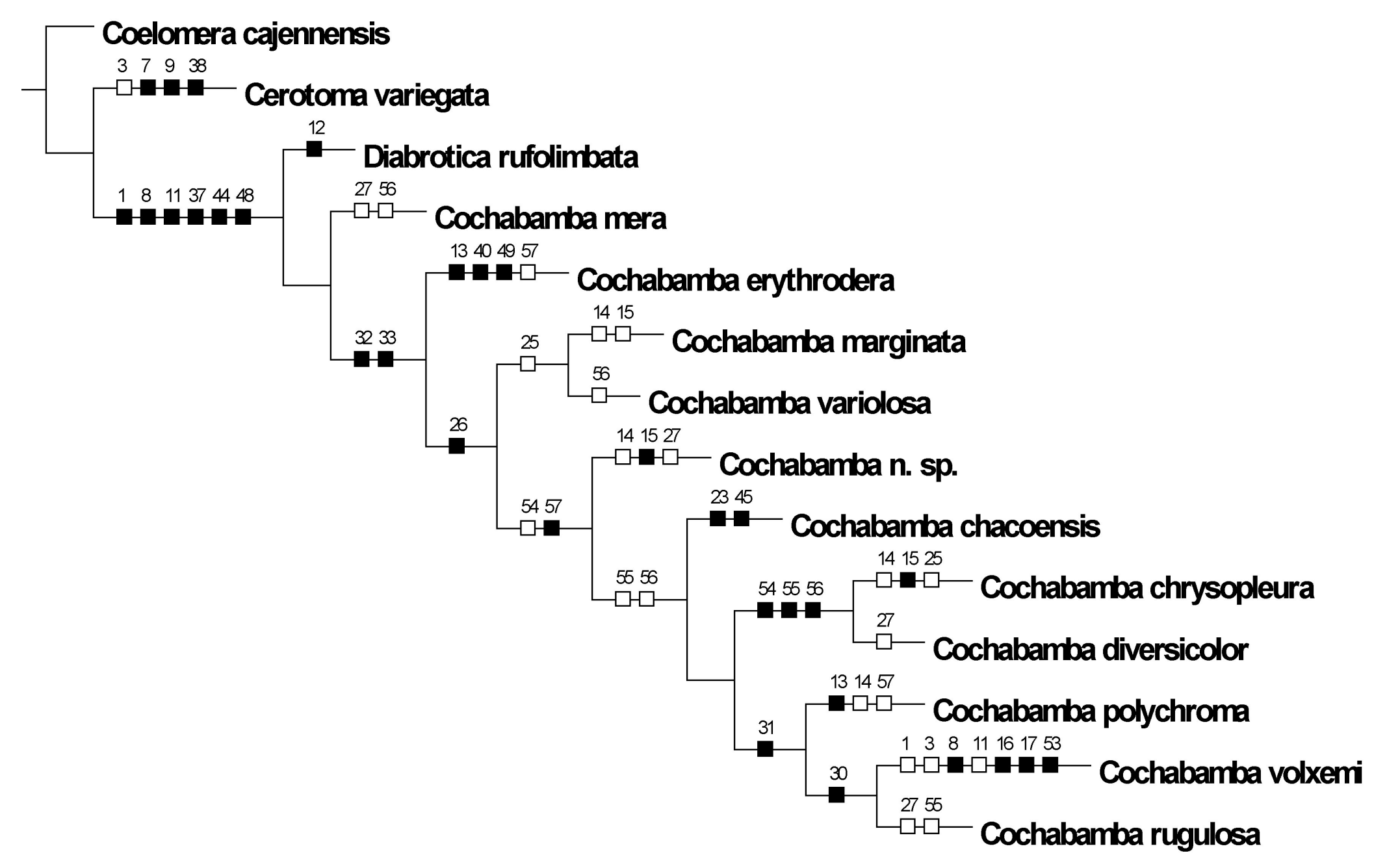

Figura 4: Cladograma resultante da busca exaustiva com pesos iguais, excluindo-se o grupo-externo Paranapiacaba teinturieri $(\mathrm{C}=95$; $\mathrm{IC}=80 ; \mathrm{IR}=64)$. 

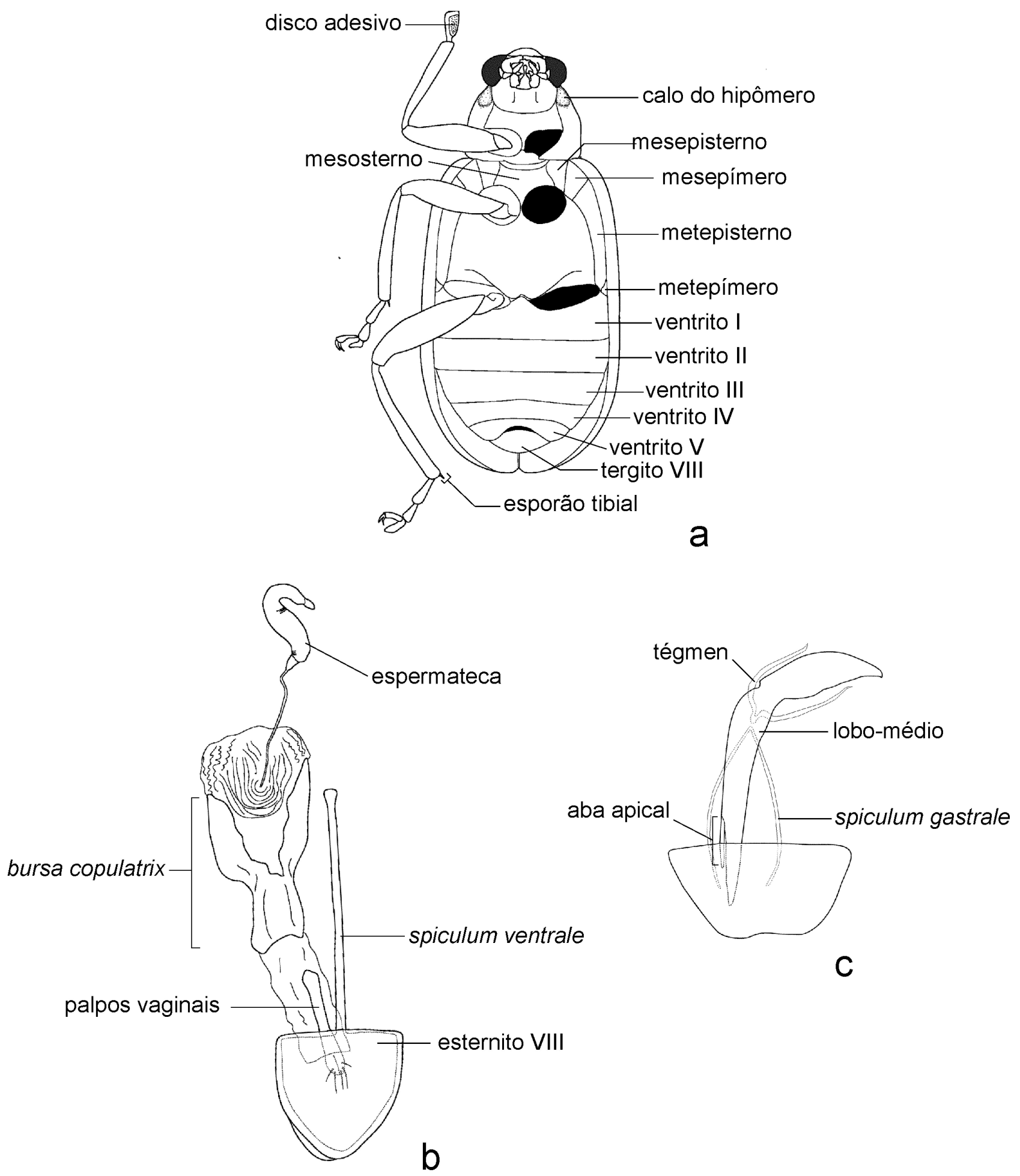

Figura 5: Diagramas esquemáticos. a: Hábito ventral (Modificado de Wilcox, 1965); b: Genitália feminina; c: Genitália masculina. 


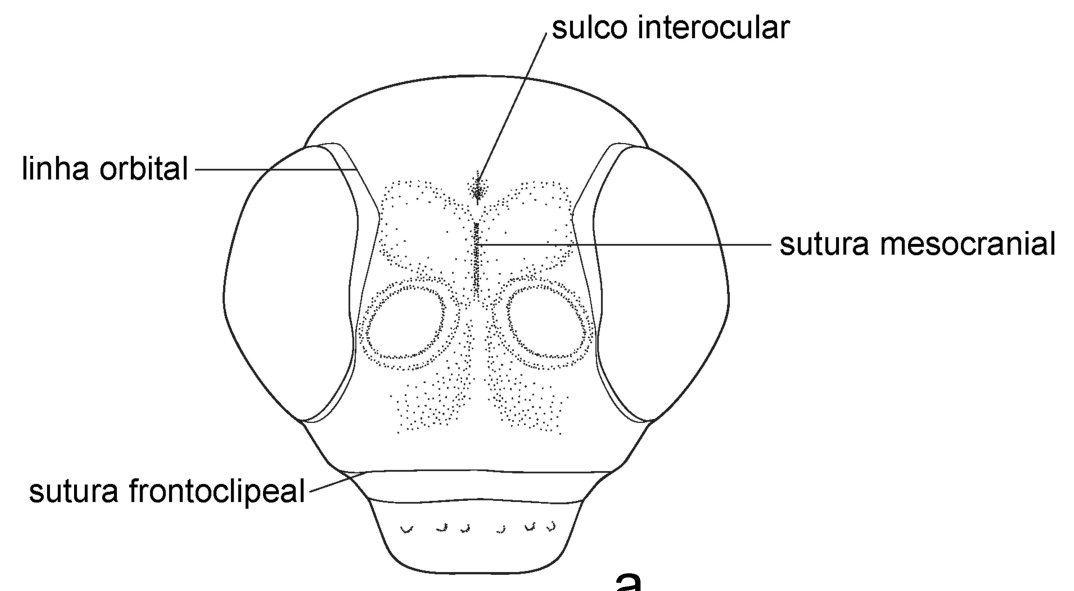

a
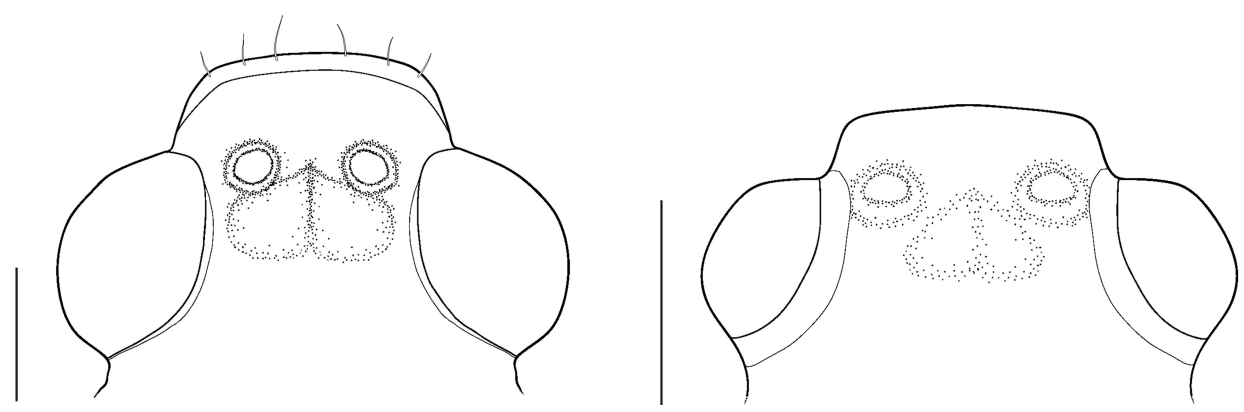

b

C

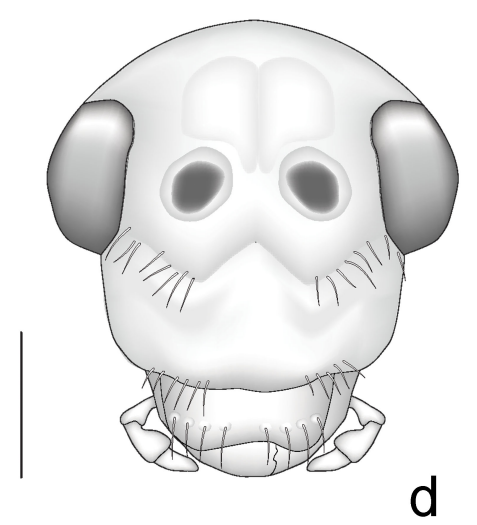

Figura 6: Cabeças. a: Diagrama esquemático de cabeça generalizada de Cochabamba, vista frontal; b: Cochabamba marginata, vista dorsal; c: Paranapiacaba volxemi, vista dorsal; d: Cerotoma variegata, vista frontal. Escala: $1 \mathrm{~mm}$. 

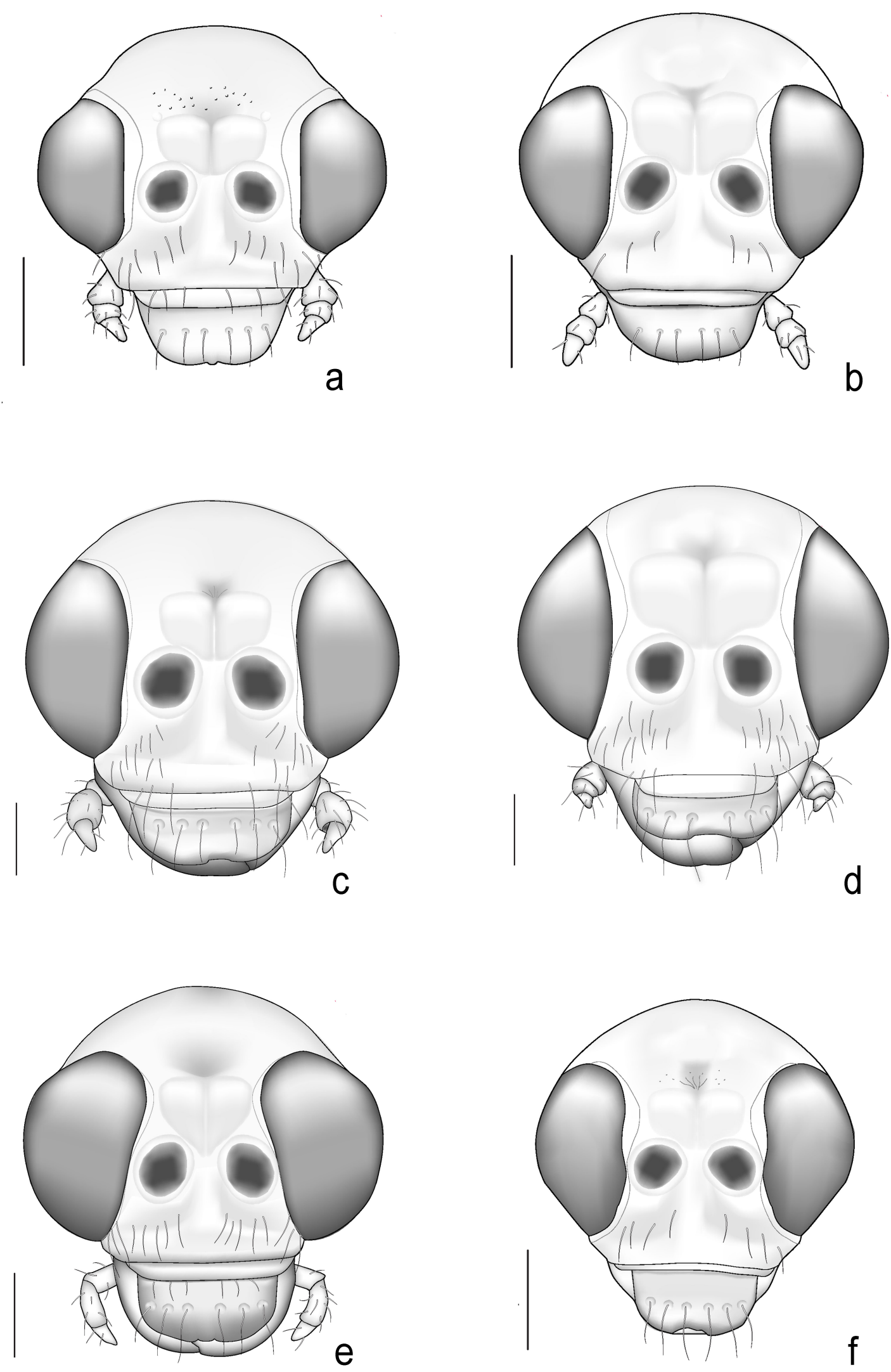

Figura 7: Cabeças, vista frontal. a: Cochabamba chacoensis; b: C. chrysopleura; c: C. diversicolor; d: C. erythrodera; e: C. marginata; f: C. mera. Escala: 2,5 mm. 

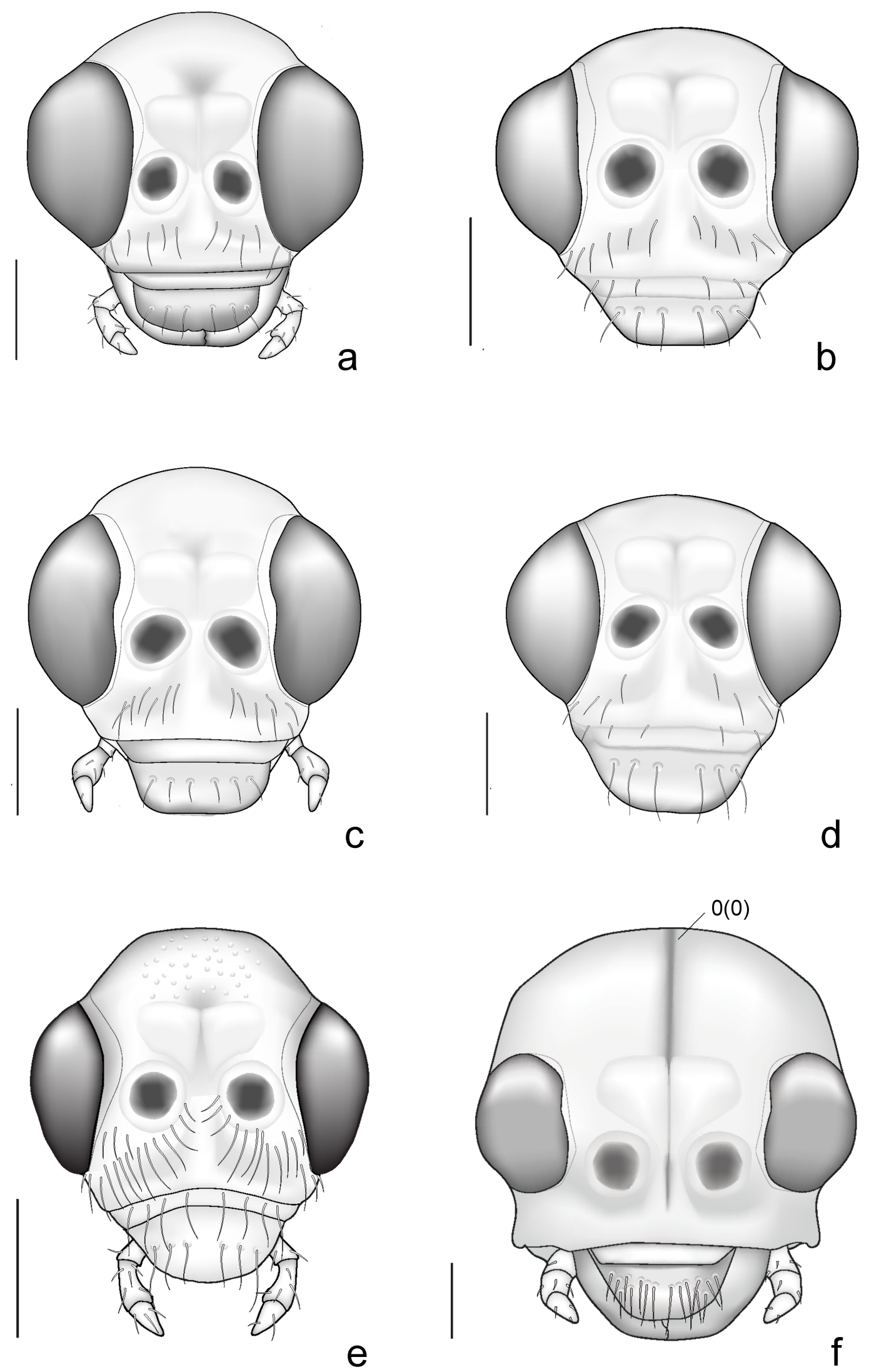

Figura 8: Cabeças, vista frontal. a: Cochabamba polychroma; b: C. rugulosa; c: C. variolosa; d: C. n. sp.; e: Paranapiacaba volxemi; f: Coelomera cajennensis. Escala: 2,5 $\mathrm{mm}$. 

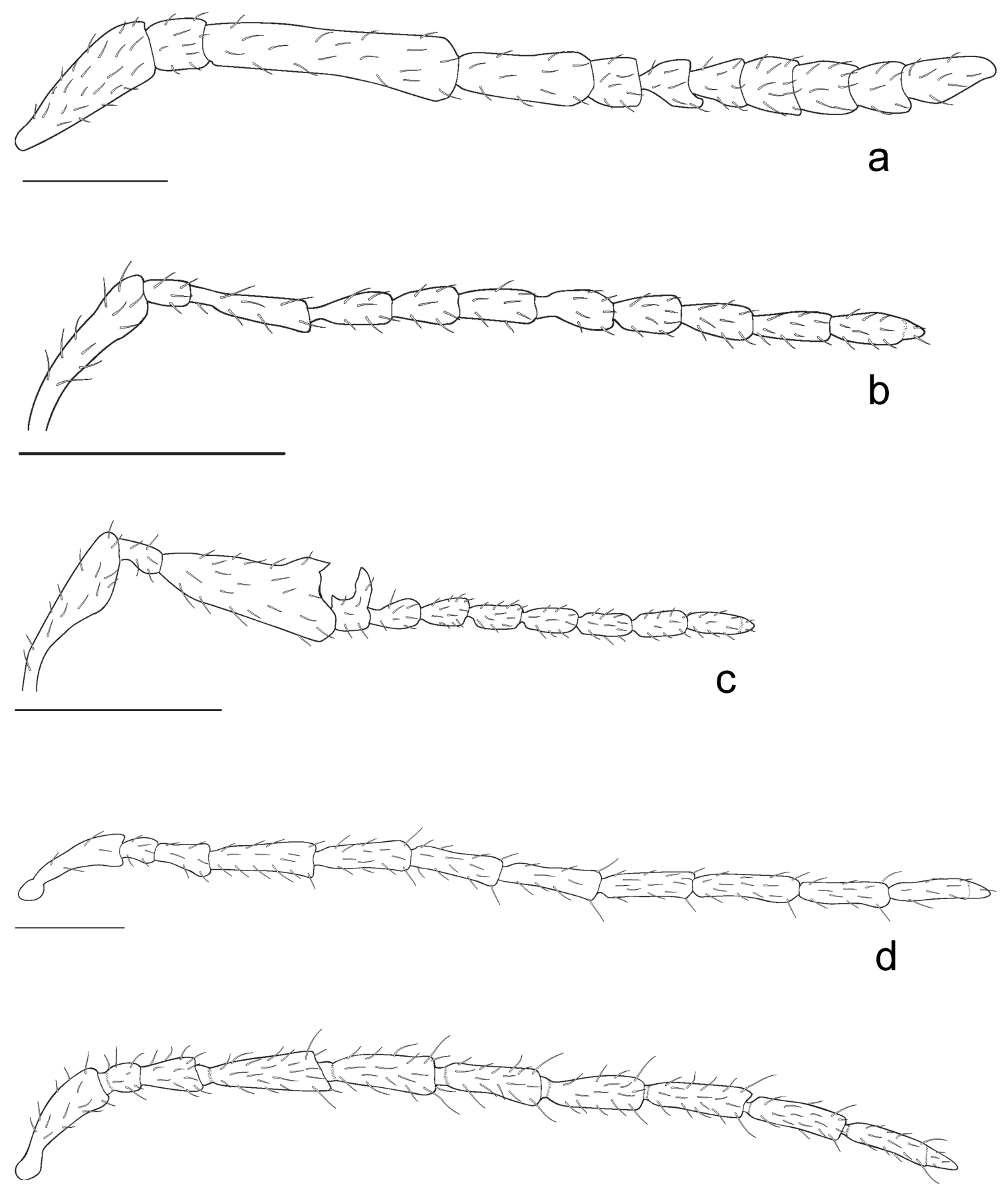

e

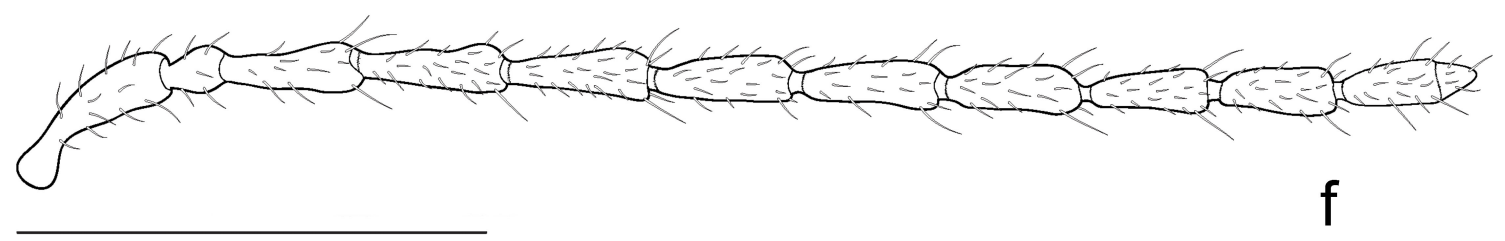

Figura 9: Antenas, vista lateral. a: Coelomera cajennensis, macho; b: Cerotoma variegata, fêmea; c: Cerotoma variegata, macho; d: Diabrotica rufolimbata, macho; e: Cochabamba marginata, macho; f: Paranapiacaba volxemi, macho. Escala: $2 \mathrm{~mm}$. 

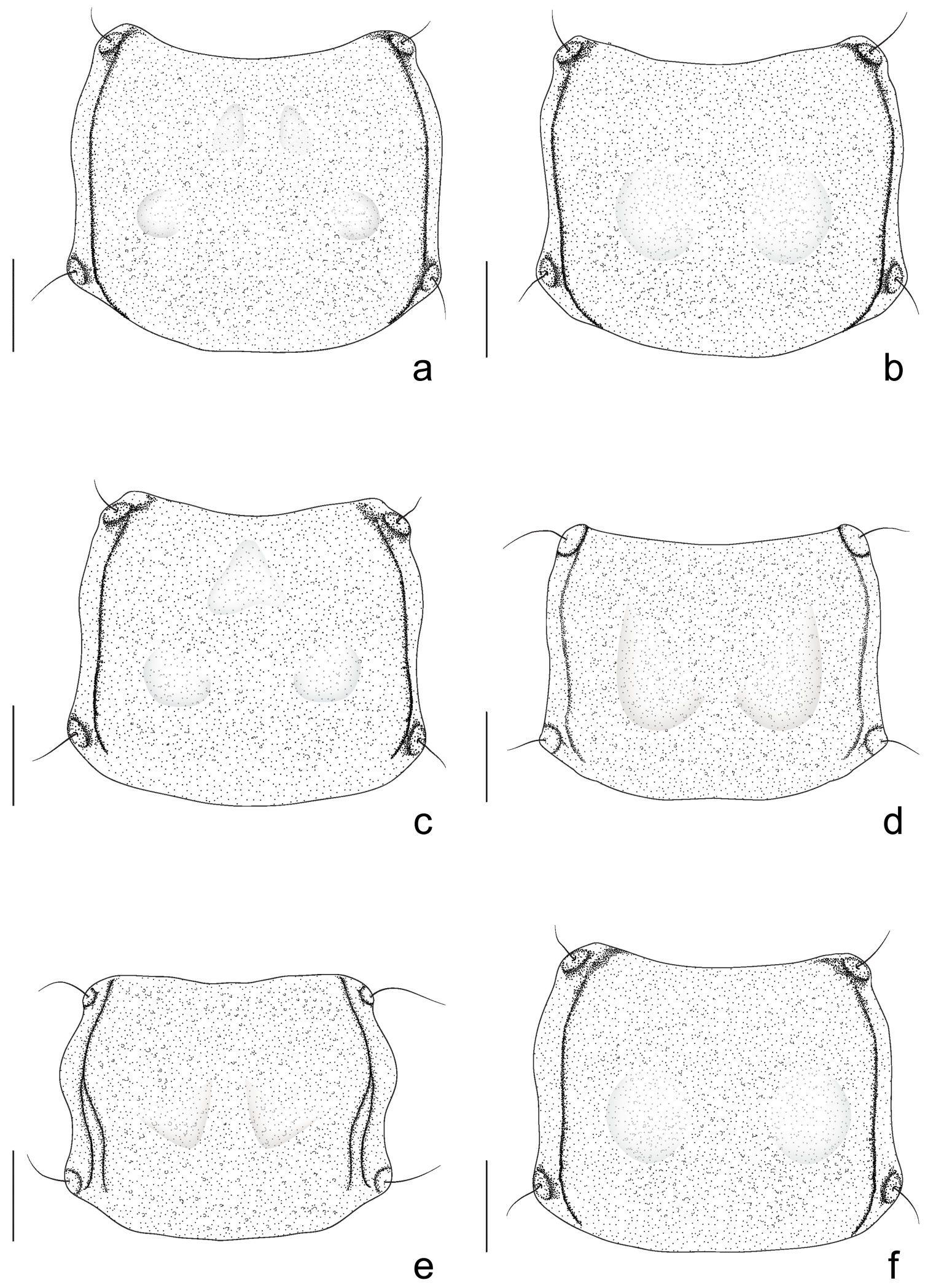

Figura 10: Pronotos. a: Cochabamba chacoensis; b: C. chrysopleura; c: C. diversicolor; d: C. erythrodera; e: C. marginata; f: C. mera. Escala: 0,5 mm. 

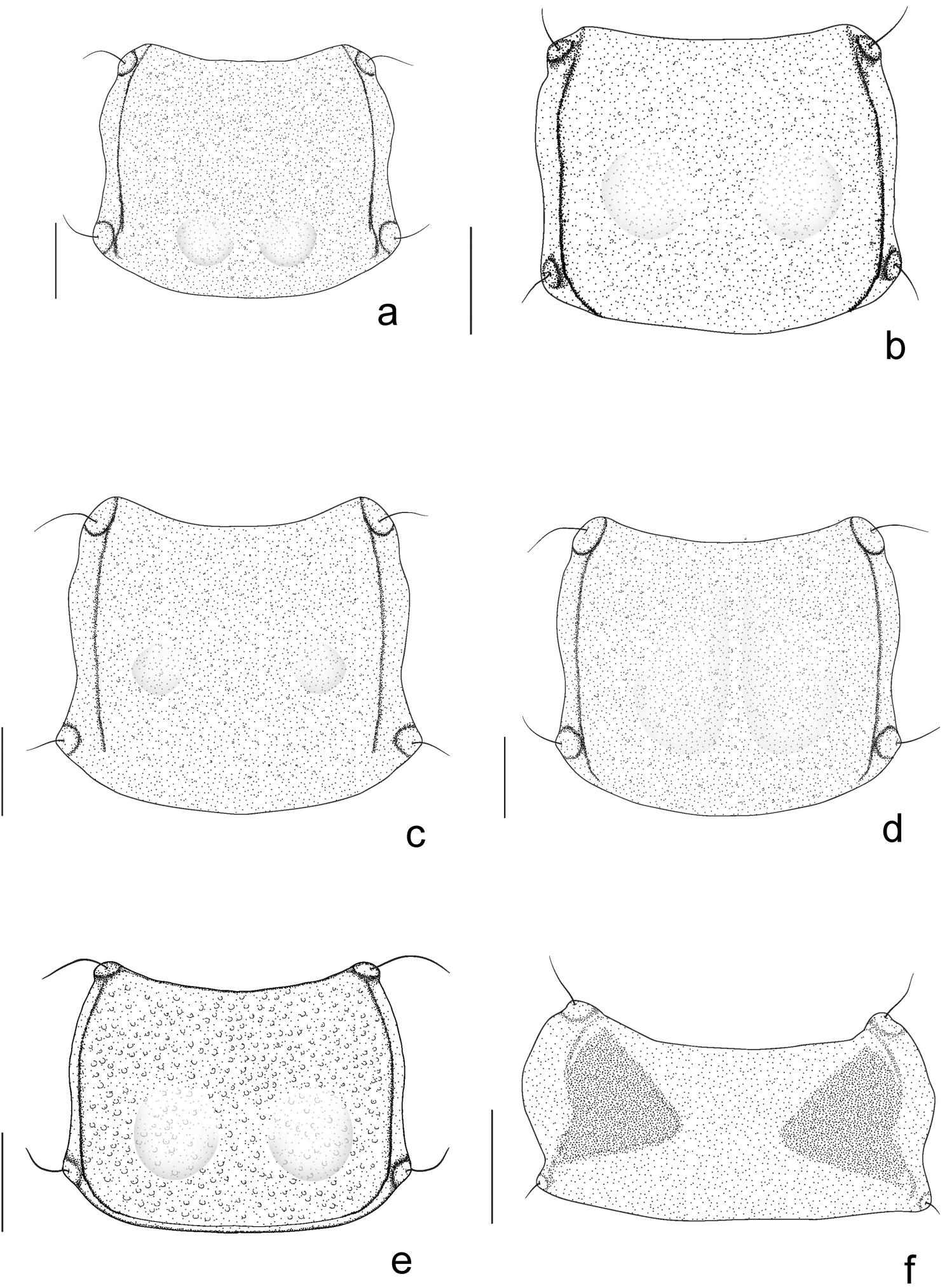

Figura 11: Pronotos. a: Cochabamba polychroma; b: C. rugulosa; c: C. variolosa; d: C. n. sp.; e: Paranapiacaba volxemi; f: Coelomera cajennensis. Escala: 0,5 mm. 

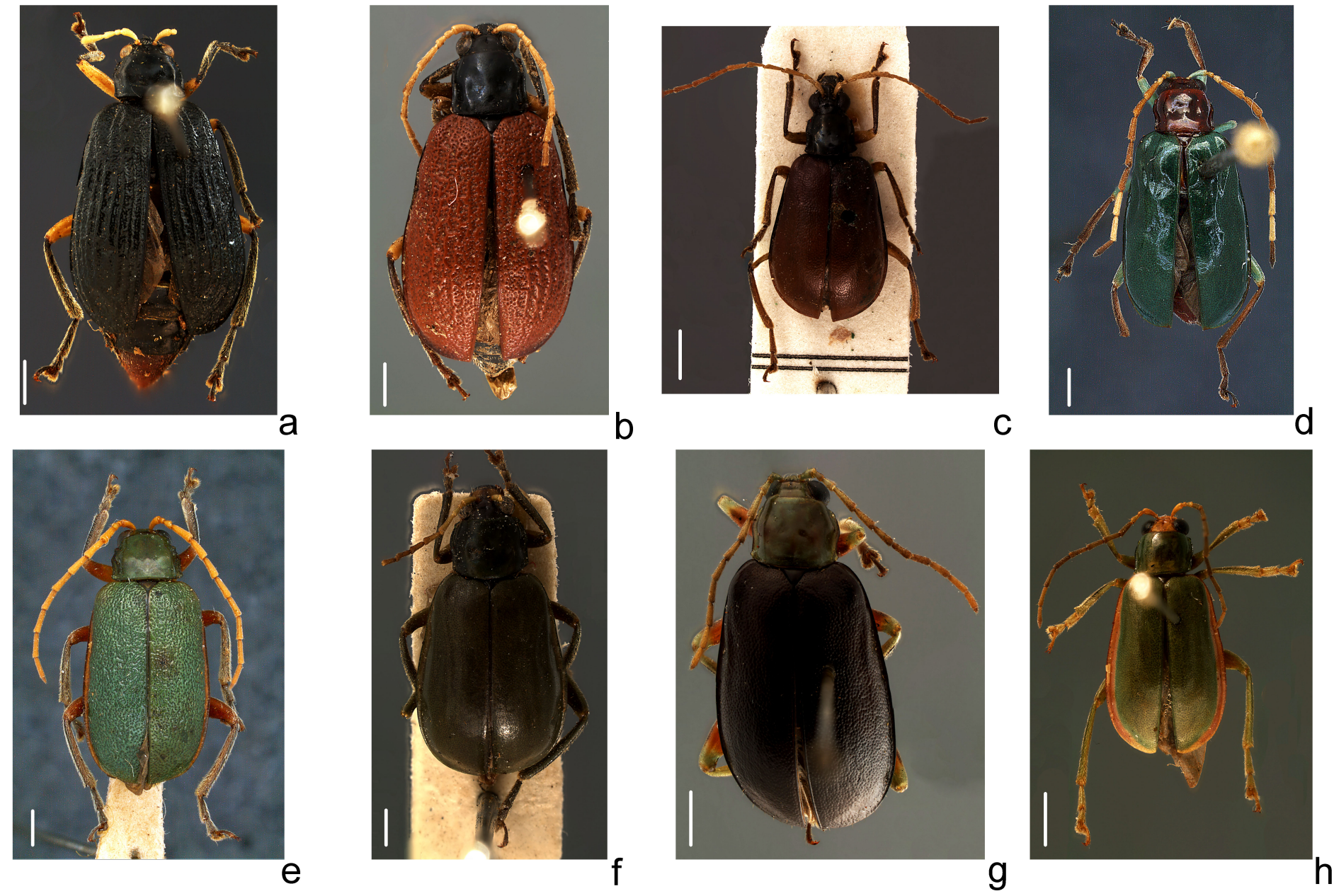

Figura 12: Hábitos dorsais. a: Cochabamba chacoensis; b: C. chrysopleura; c: C. diversicolor; d: C. erythrodera; e: C. marginata; f: C. mera; g: C. polychroma; h: C. rufolimbata. Escala: $1 \mathrm{~mm}$. 

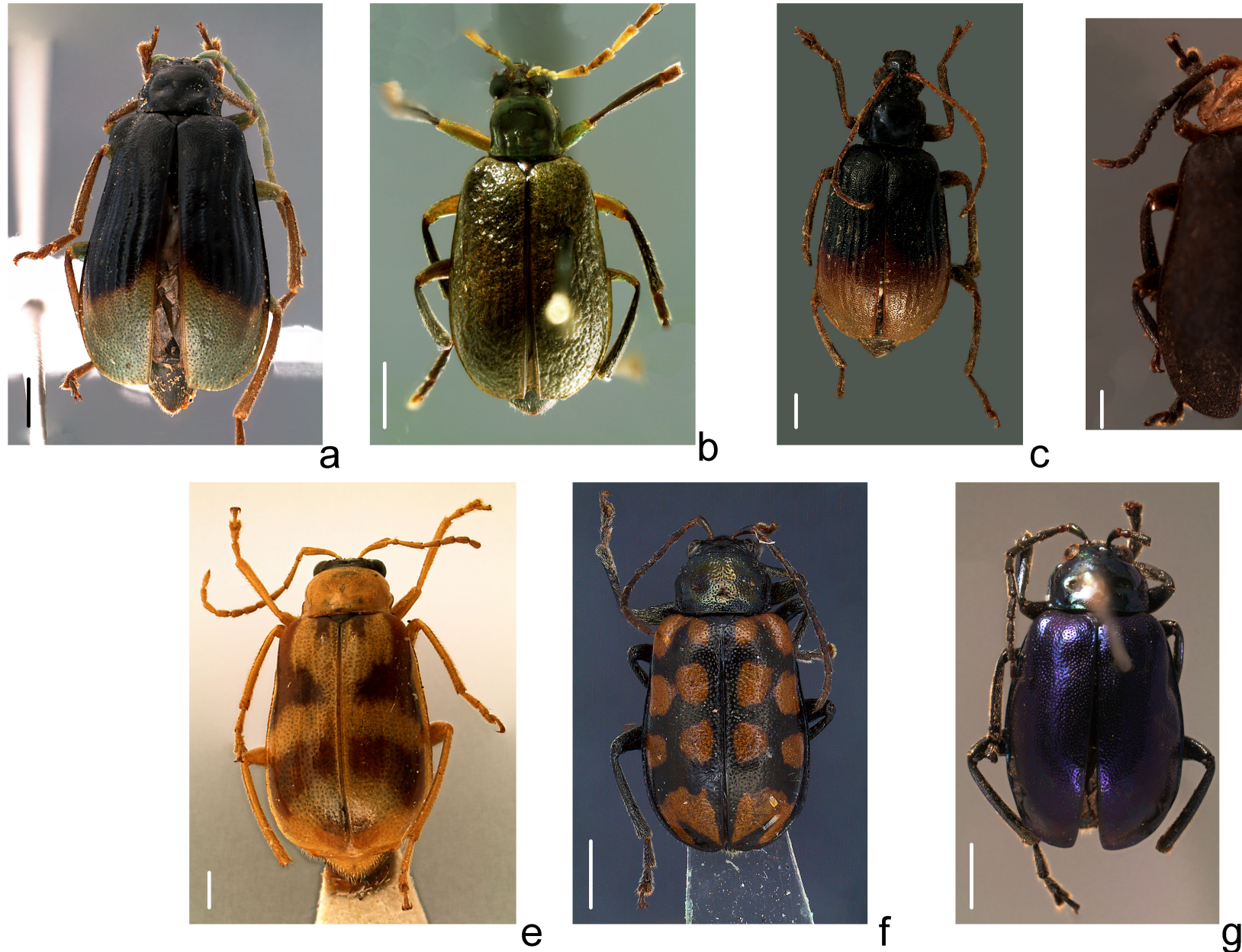

Figura 13: Hábitos dorsais. a: C. rugulosa; b: C. variolosa; c: C. n. sp.; d: Coelomera cajennensis; e: Coelomera cajennensis; f: Cerotoma variegata; g: Paranapiacaba volxemi; h: P. teinturieri. Escala: $1 \mathrm{~mm}$. 


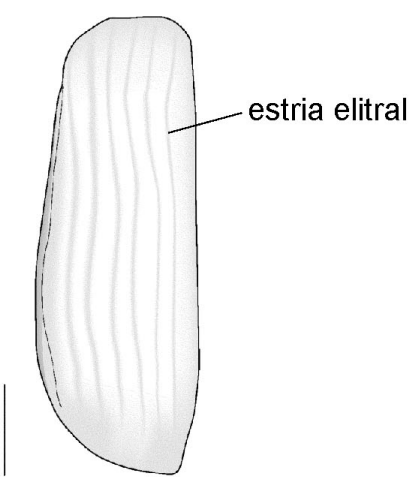

a

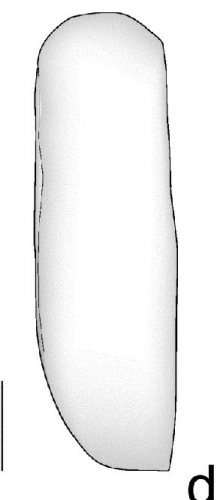

d

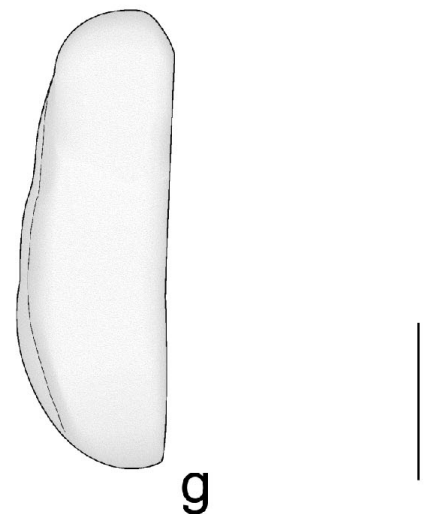

g

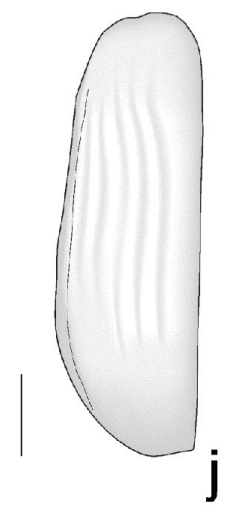

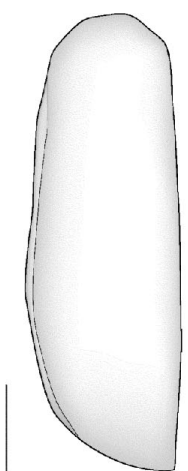

b

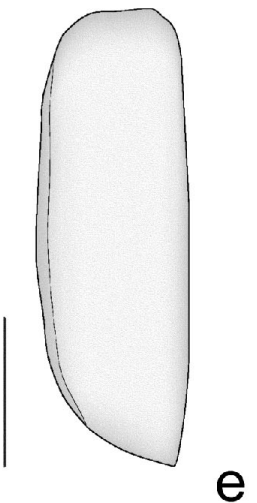

e

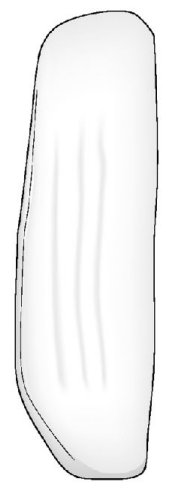

$\mathrm{h}$

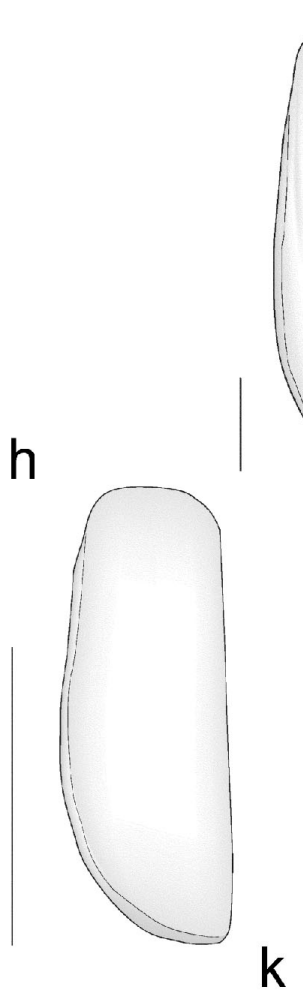

$\mathrm{k}$

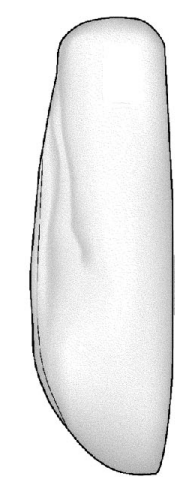

C

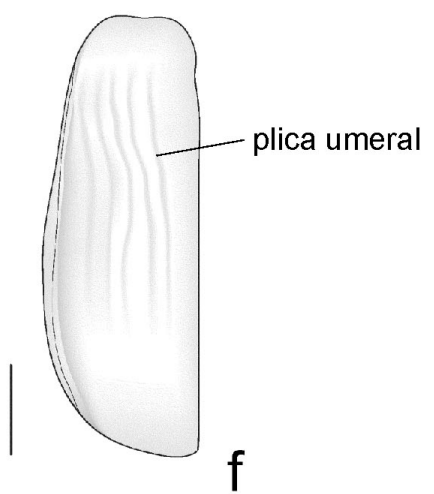

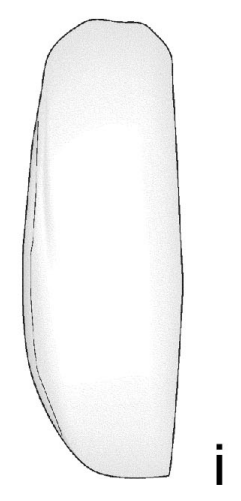

Figura 14: Élitros esquerdos, em vista dorsal. a: Cochabamba chacoensis; b: C. chrysopleura; c: C. diversicolor; d: C. erythrodera; e C. marginata; f: C. mera; g: C. polychroma; h: C. rugulosa; i: C. variolosa; j: C. n. sp.; k: Paranapiacaba volxemi. Escala: $2,5 \mathrm{~mm}$. 

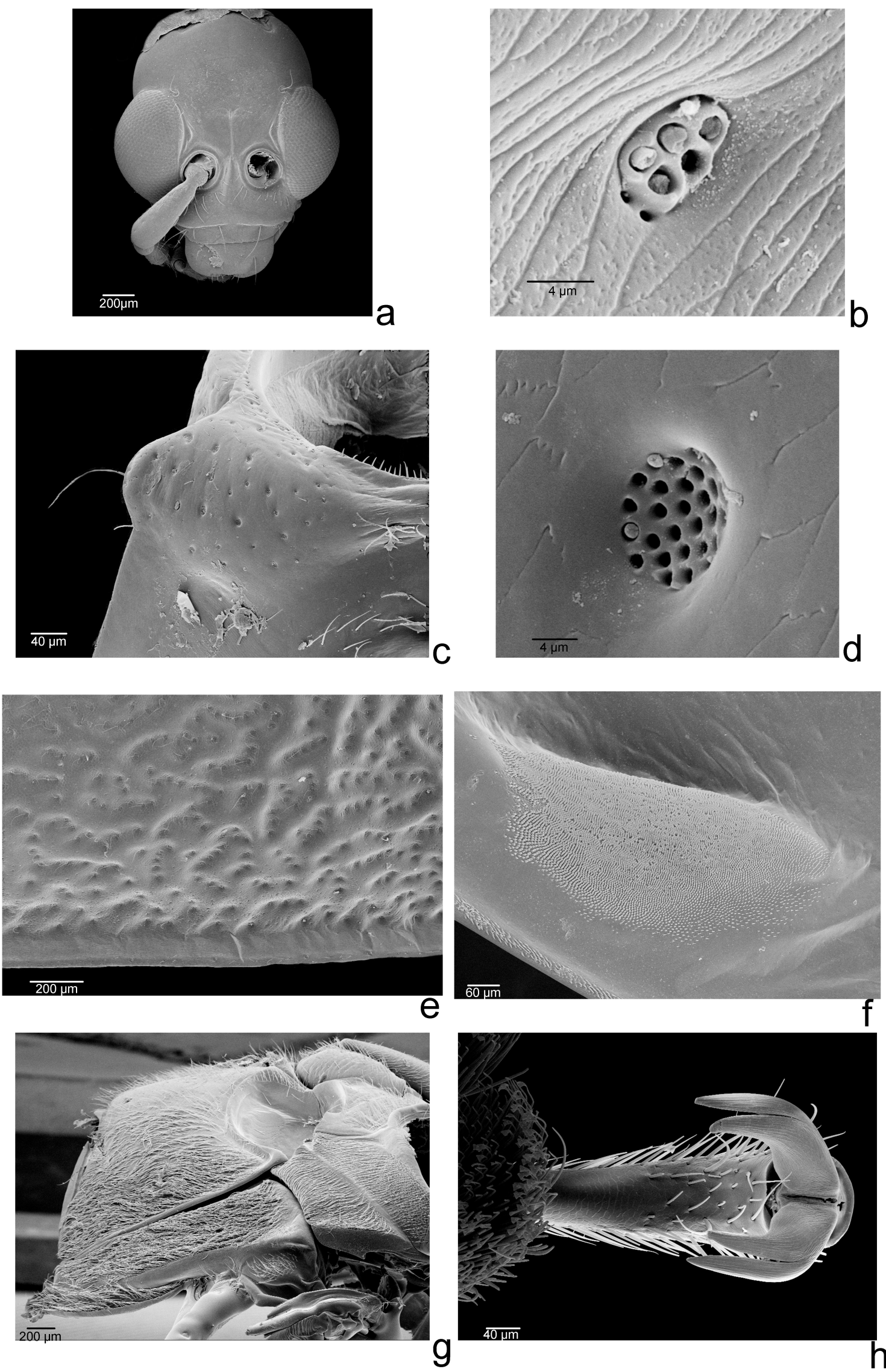

Figura 15: Micrografias eletrônicas de varredura (C. marginata). a: Cabeça, vista dorso-frontal; b: Detalhe de abertura glandular do pronoto; c: Calo do hipômero; d: Detalhe de abertura glandular do calo do hipômero; e: Detalhe do tegumento elitral dorsal; f: Superfície elitral ventral, espículos do binding patch; g: Tórax, vista lateral, detalhe da pilosidade dos escleritos; h: Garras tarsais. 

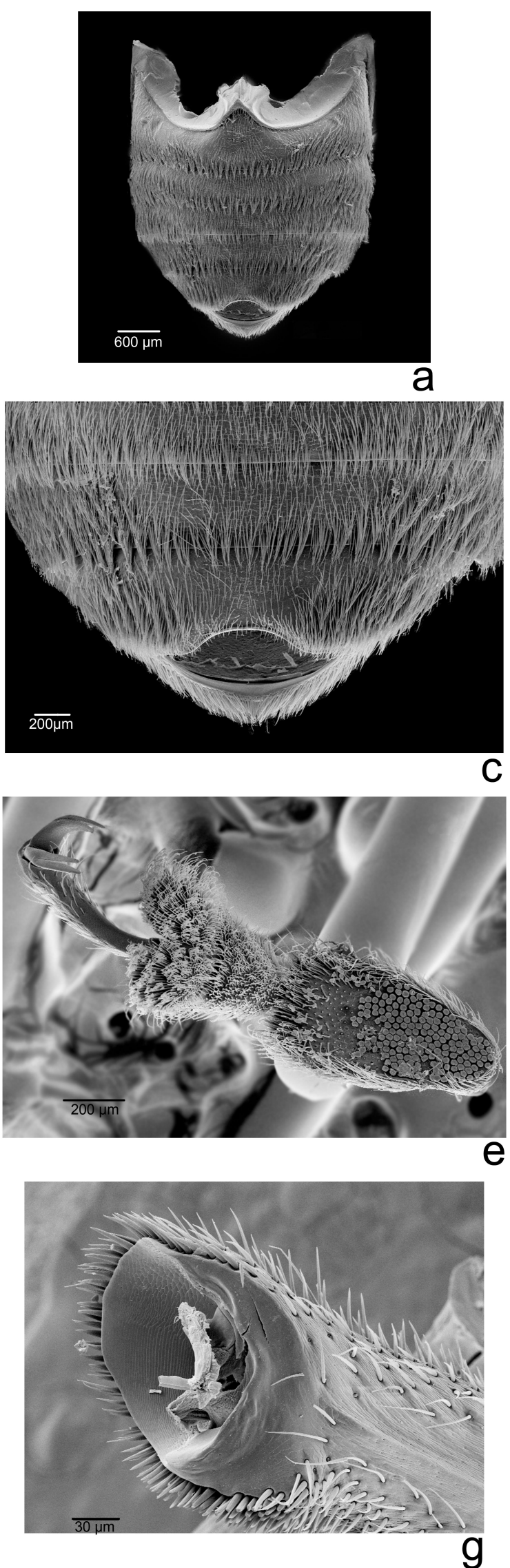
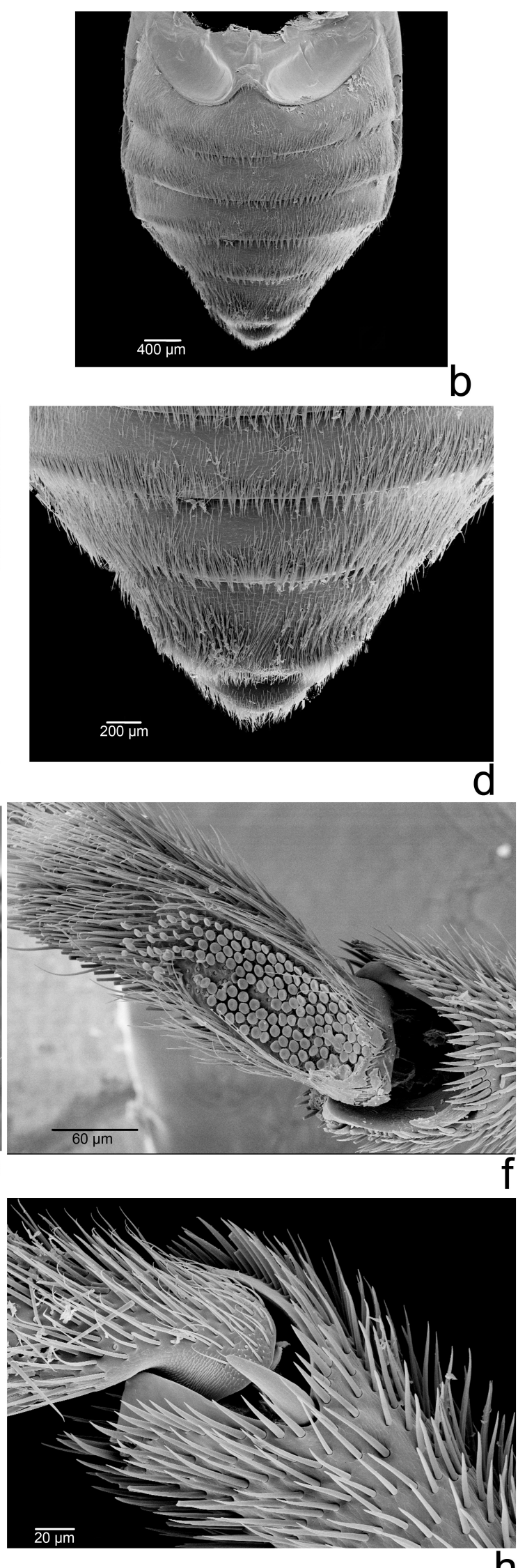

h

Figura 16: Micrografias eletrônicas de varredura (C. marginata). Abdômen, vista ventral, macho $(\mathbf{a}, \mathbf{c})$ e fêmea $(\mathbf{b}, \mathbf{d})$; e: Tarso da perna protorácica do macho, visão ventral; f: Detalhe do disco adesivo do tarsômero I da perna protorácica do macho; Detalhe do ápice da tíbia da perna protorácica do macho (g) e da fêmea (h). 

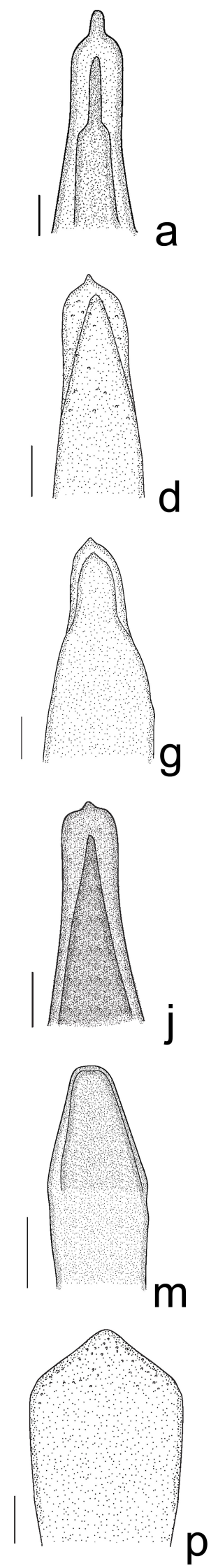

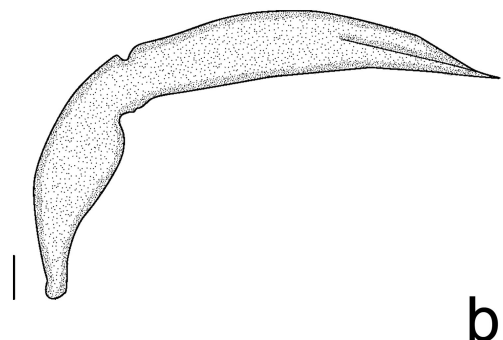

b

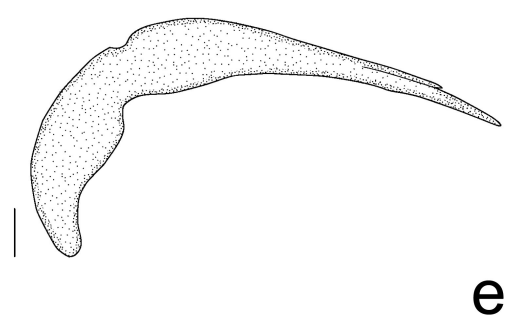

e

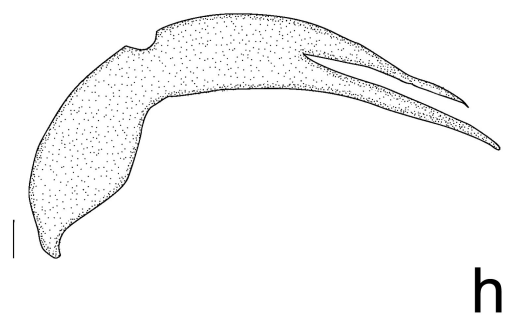

h
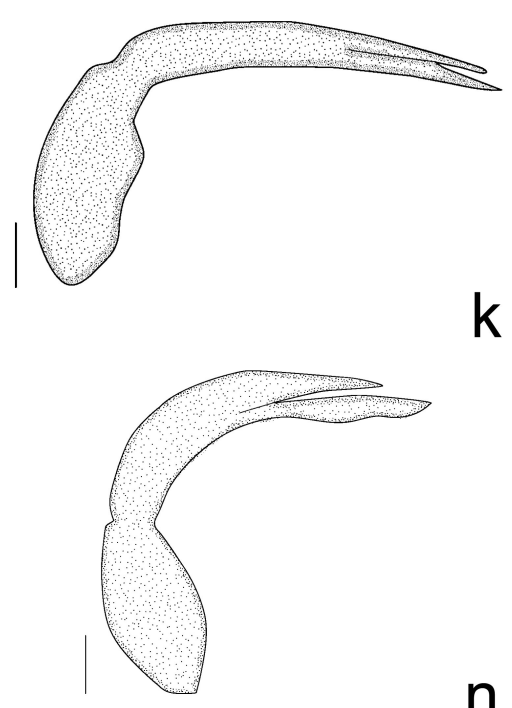

$\mathrm{n}$

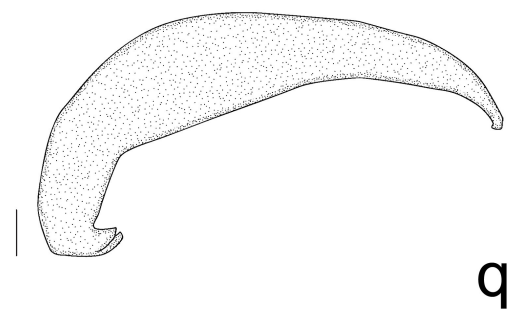

C

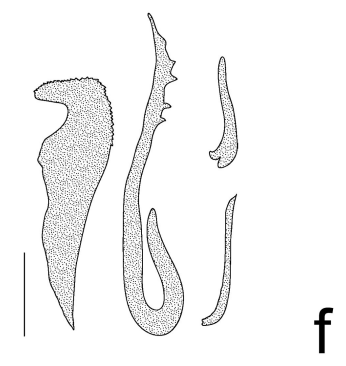

$f$
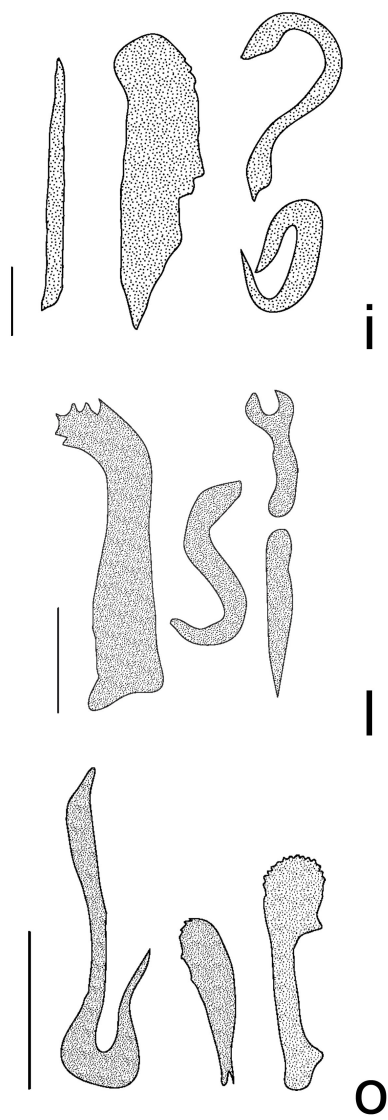

Figura 17: Lobos-médios: ápice em em vista dorsal (a, d, g, j, m, p), vista lateral (b, e, h, k, n, q), e escleritos do saco interno (c, f, i, l, o). a-c: Cochabamba chacoensis (adaptado de Cabrera, 1999); d-f: C. erythrodera; g-i: C. marginata; j-l: C. polychroma; m-o: Paranapiacaba volxemi; p-q: Coelomera cajennensis. Escala: $2 \mathrm{~mm}$. 

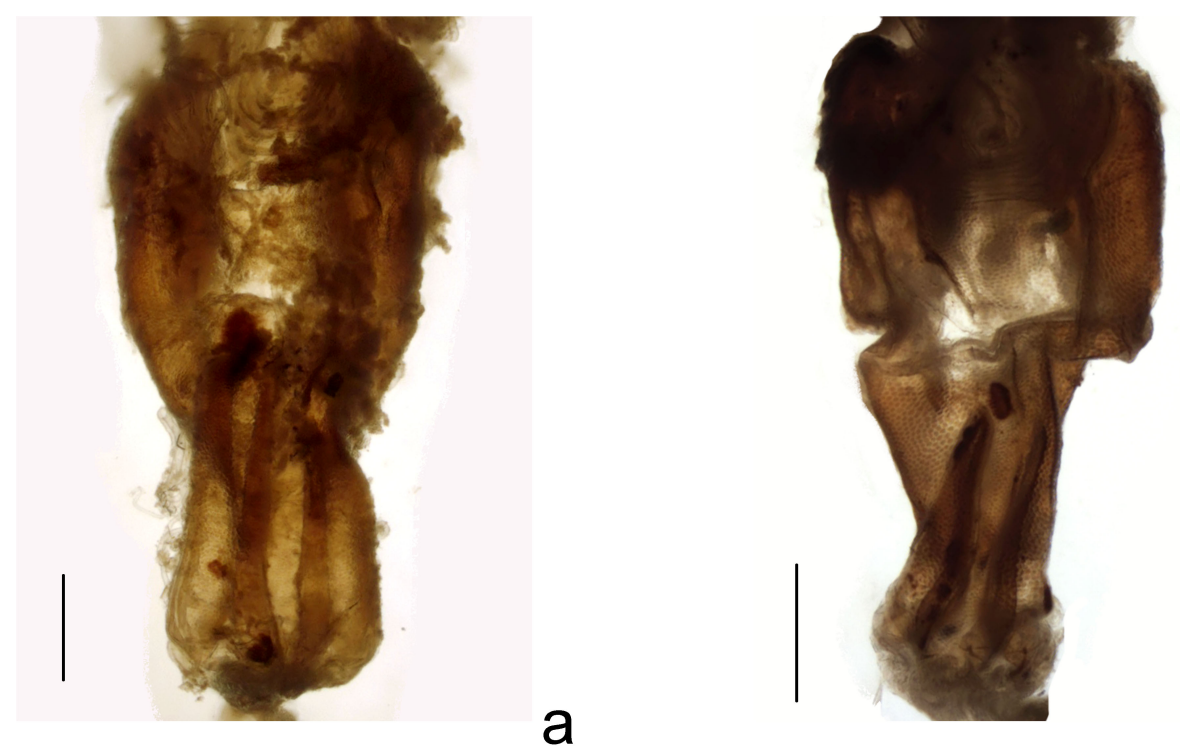

a
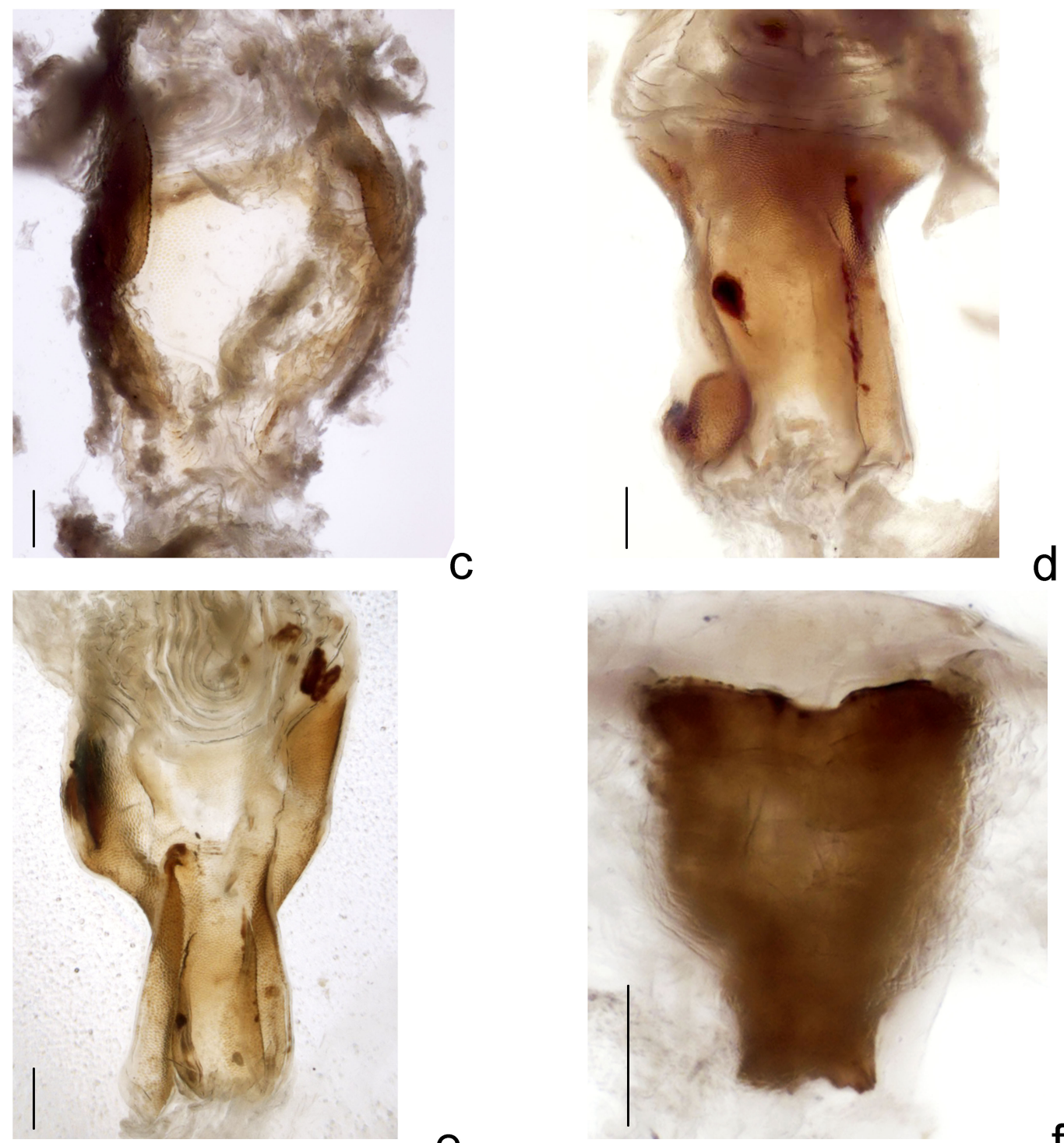

C

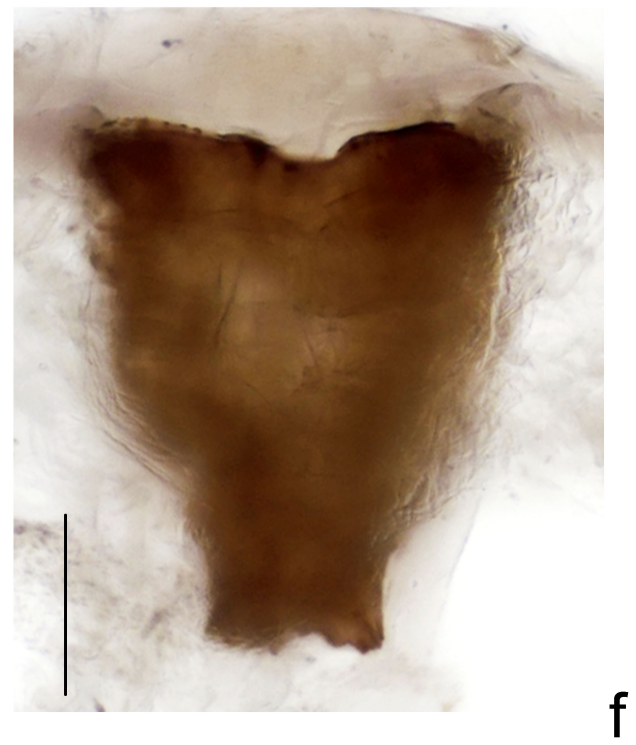

Figura 18: Região central esclerotizada da bursa copulatrix. a: Cochabamba chacoensis; b: C. chrysopleura; c: C. erythrodera; d: C. marginata; e: C.n. sp.; f: Paranapiacaba volxemi. Escala: $1 \mathrm{~mm}$. 

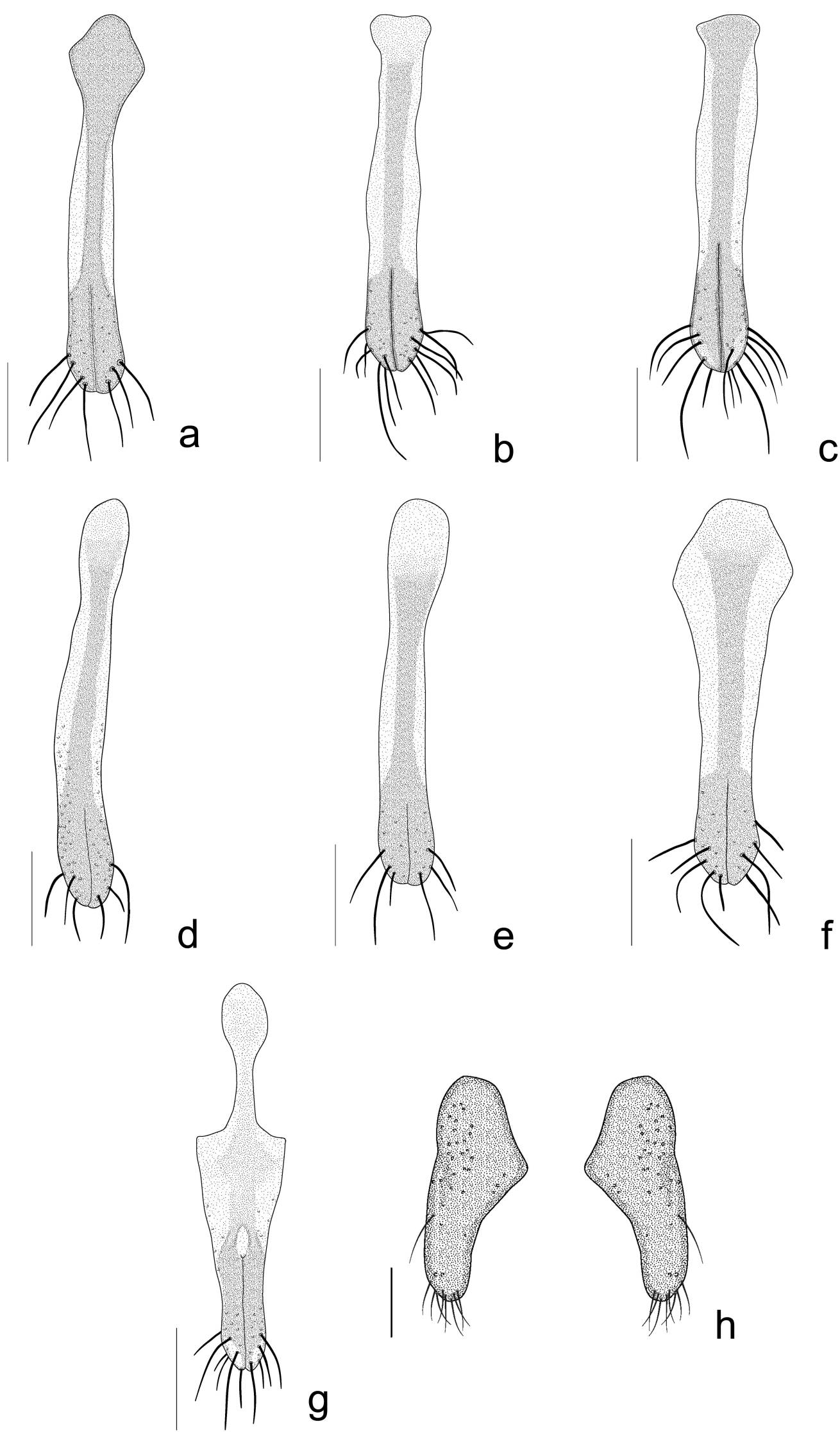

Figura 19: Palpos vaginais. a: Cochabamba chacoensis; b: C. chrysopleura; c: $C$. erythrodera; d: C. marginata; e: C. polychroma; f: C. n. sp.; g: Paranapiacaba volxemi; h: Coelomera cajennensis. Escala: $2 \mathrm{~mm}$. 

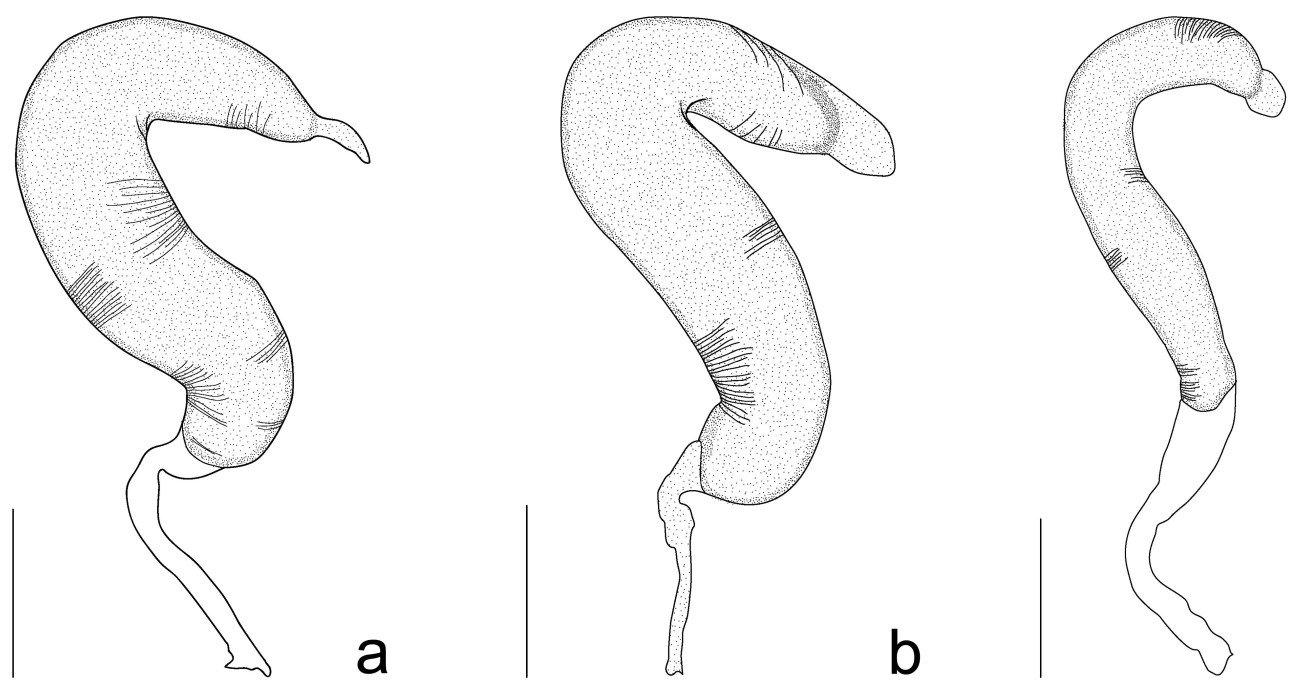

C
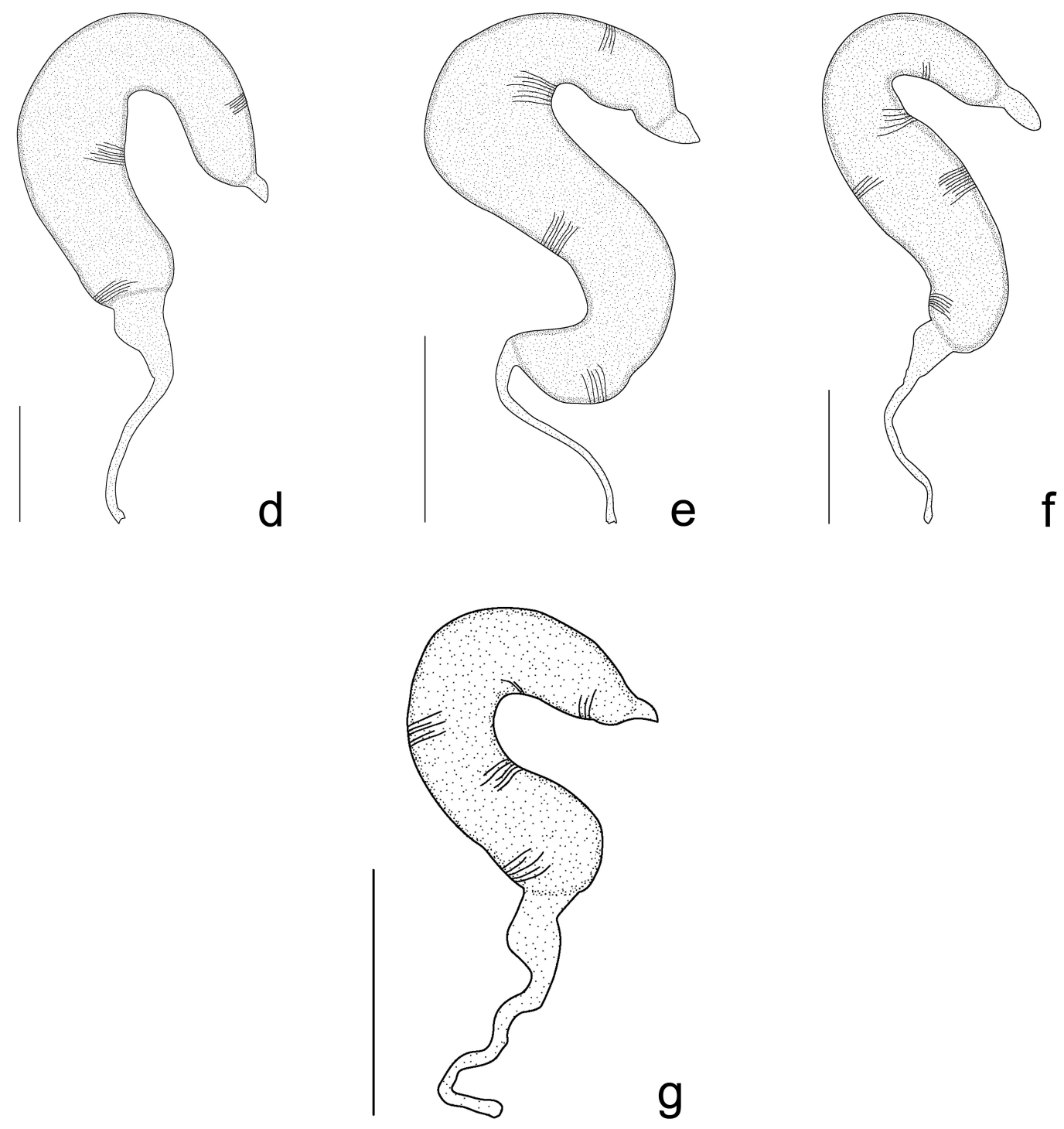

Figura 20: Espermatecas. a: Cochabamba chacoensis; b: C. chrysopleura; c: C. erythrodera; d: C. marginata; e: C. polychroma; f: C. n. sp.; g: Paranapiacaba volxemi. Escala: $2 \mathrm{~mm}$. 

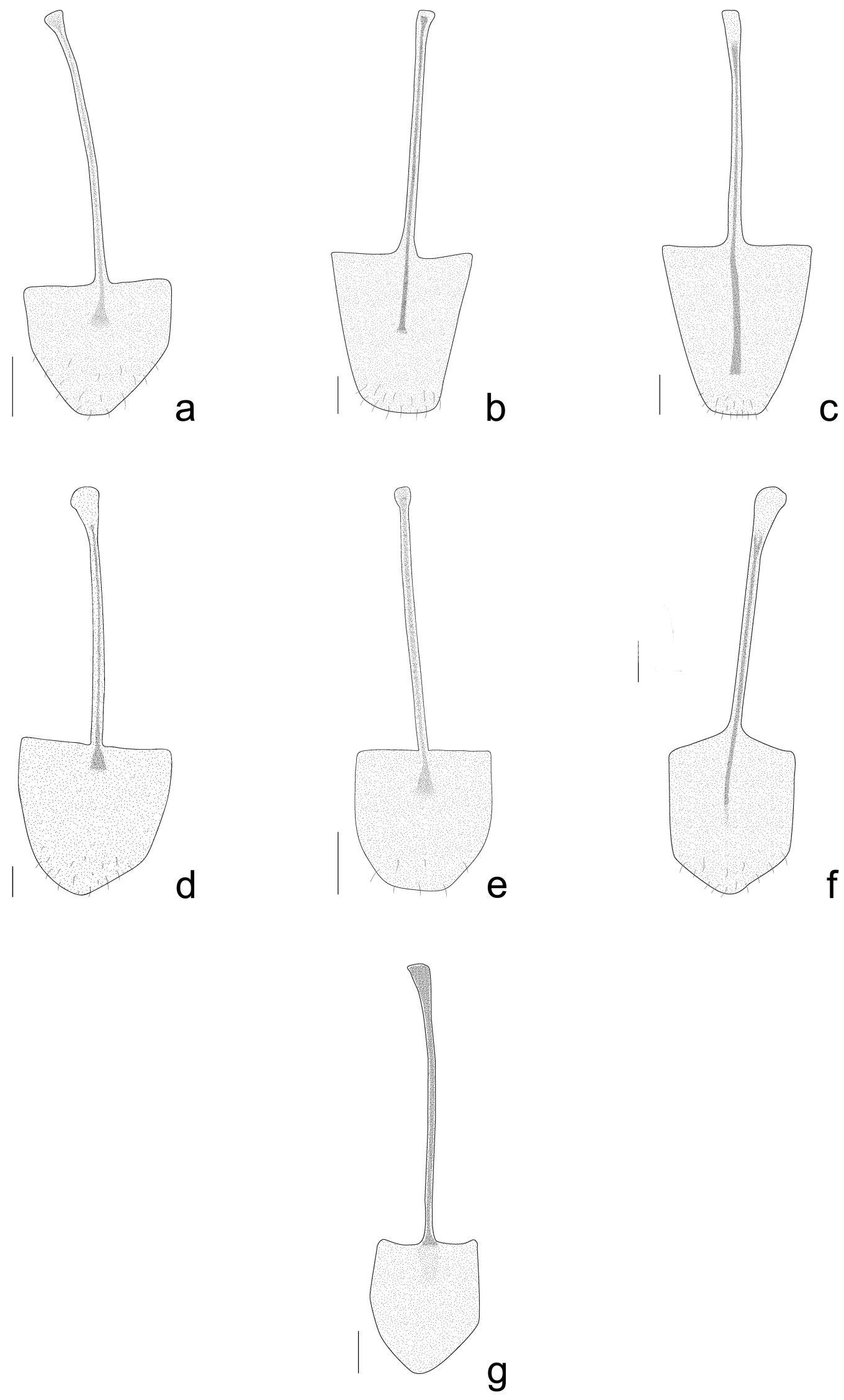

Figura 21: Esternito VIII (spiculum ventrale). a: Cochabamba chacoensis; b: C. chrysopleura; c: C. erythrodera; d: C. marginata; e: C. polychroma; f: C. n. sp.; g: Paranapiacaba volxemi. Escala: $2 \mathrm{~mm}$. 

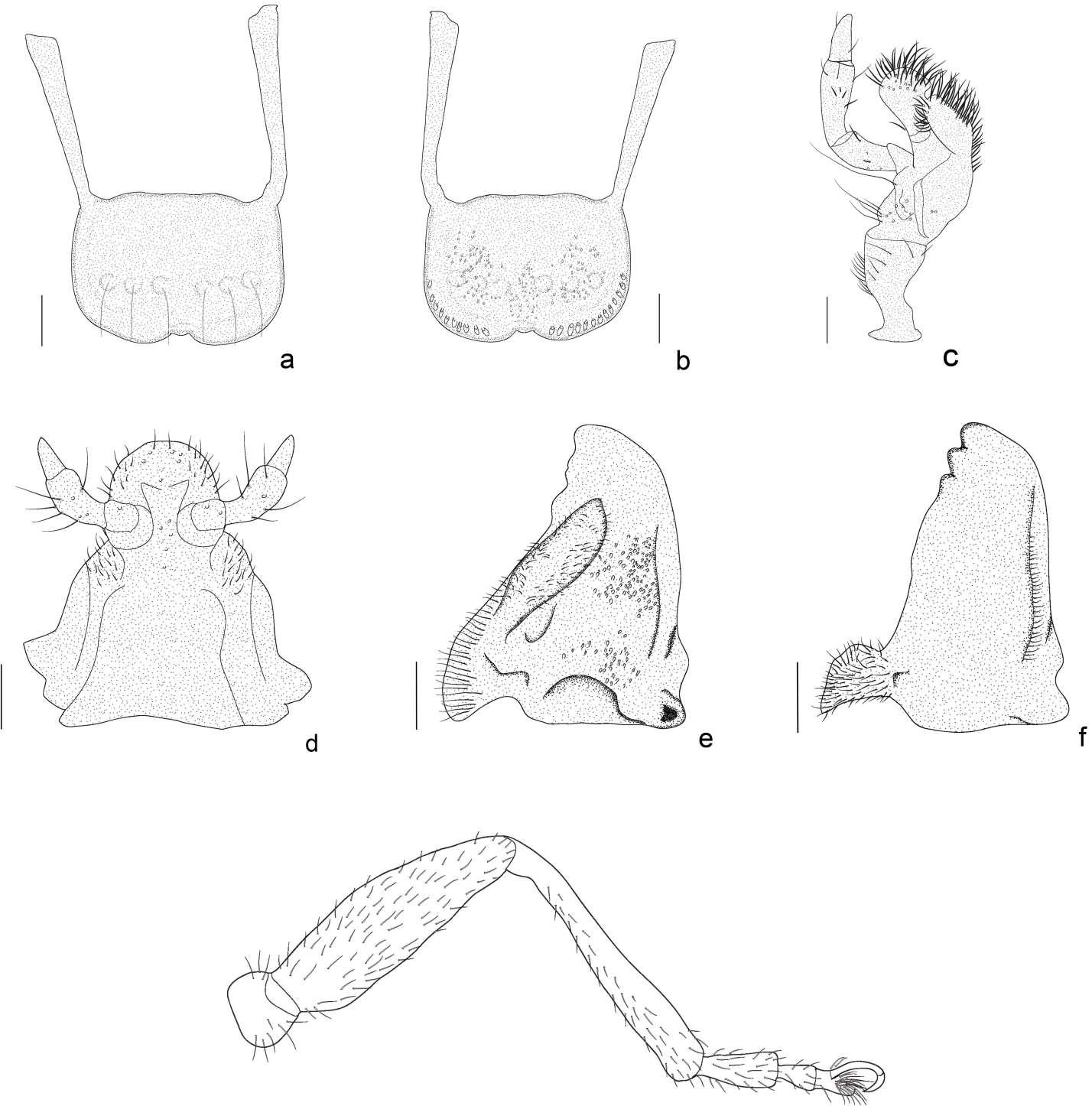

9

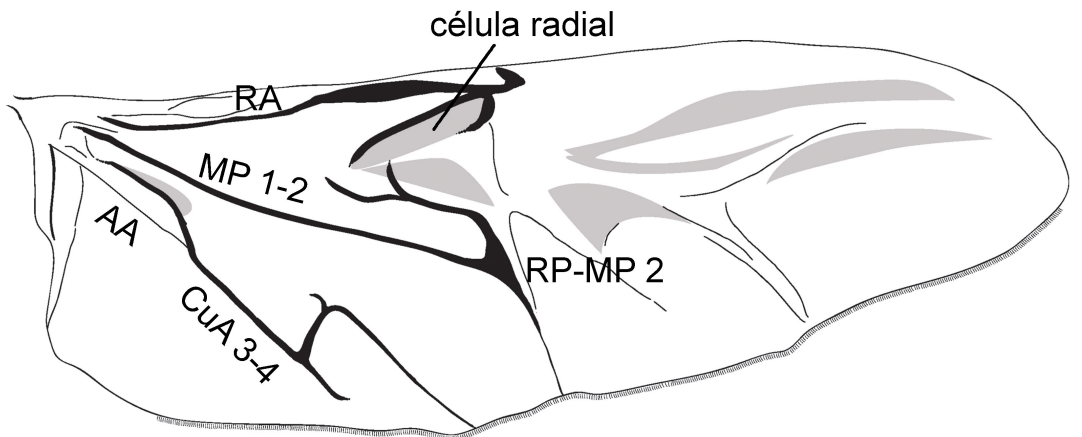

h

Figura 22: Estruturas sem variação inter-específica no gênero Cochabamba. C. marginata: a: Labro; b: Epifaringe; c: Maxila; d: Lábio; e: Mandíbula (superfície ventral); f: Mandíbula (superfície dorsal); g: Perna protorácica; C. erythrodera: h: Asa membranosa. 


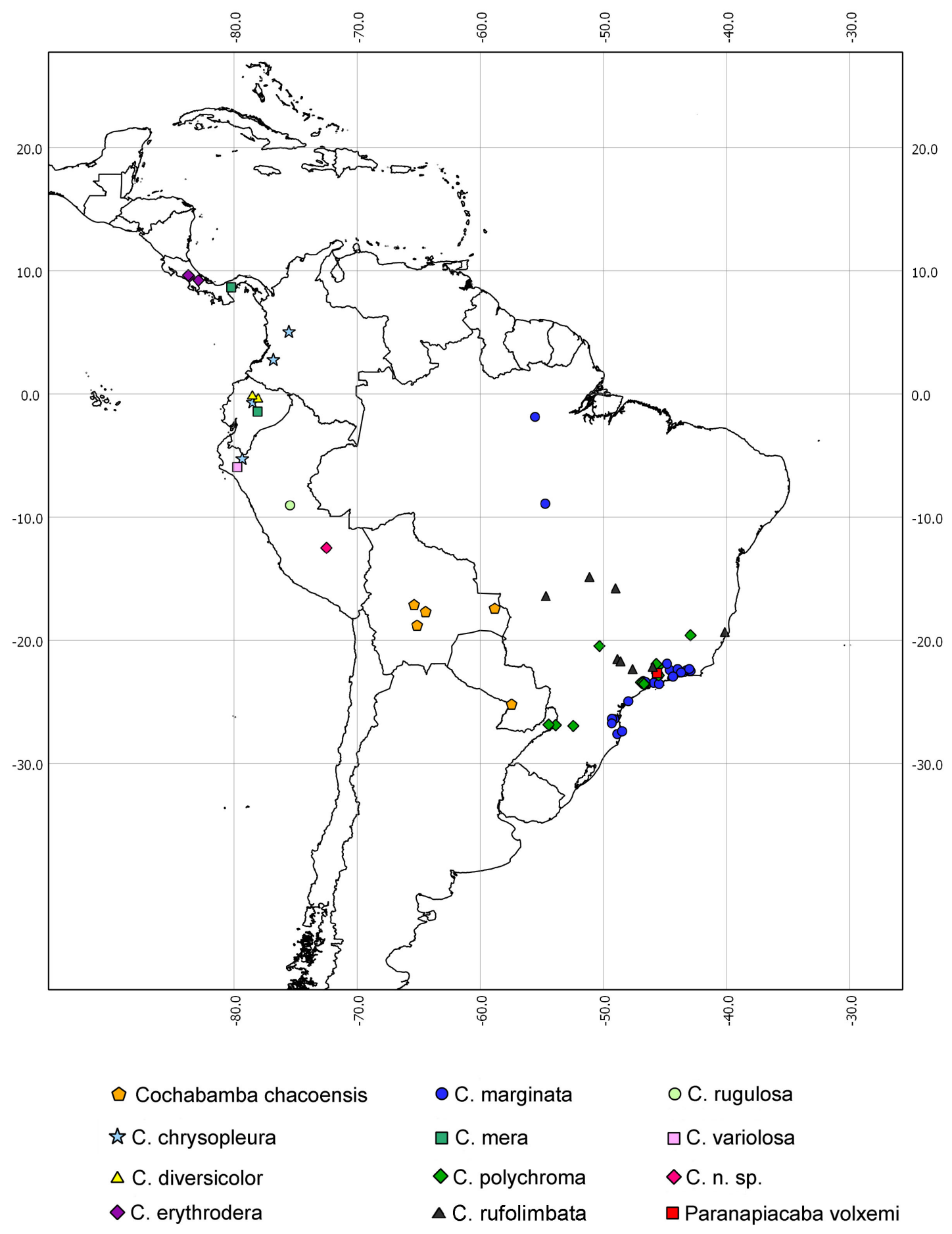

Figura 23: Distribuição geográfica das espécies de Cochabamba e Paranapiacaba volxemi, baseada nas etiquetas dos exemplares examinados e em informações da literatura: América Central e do Sul. 


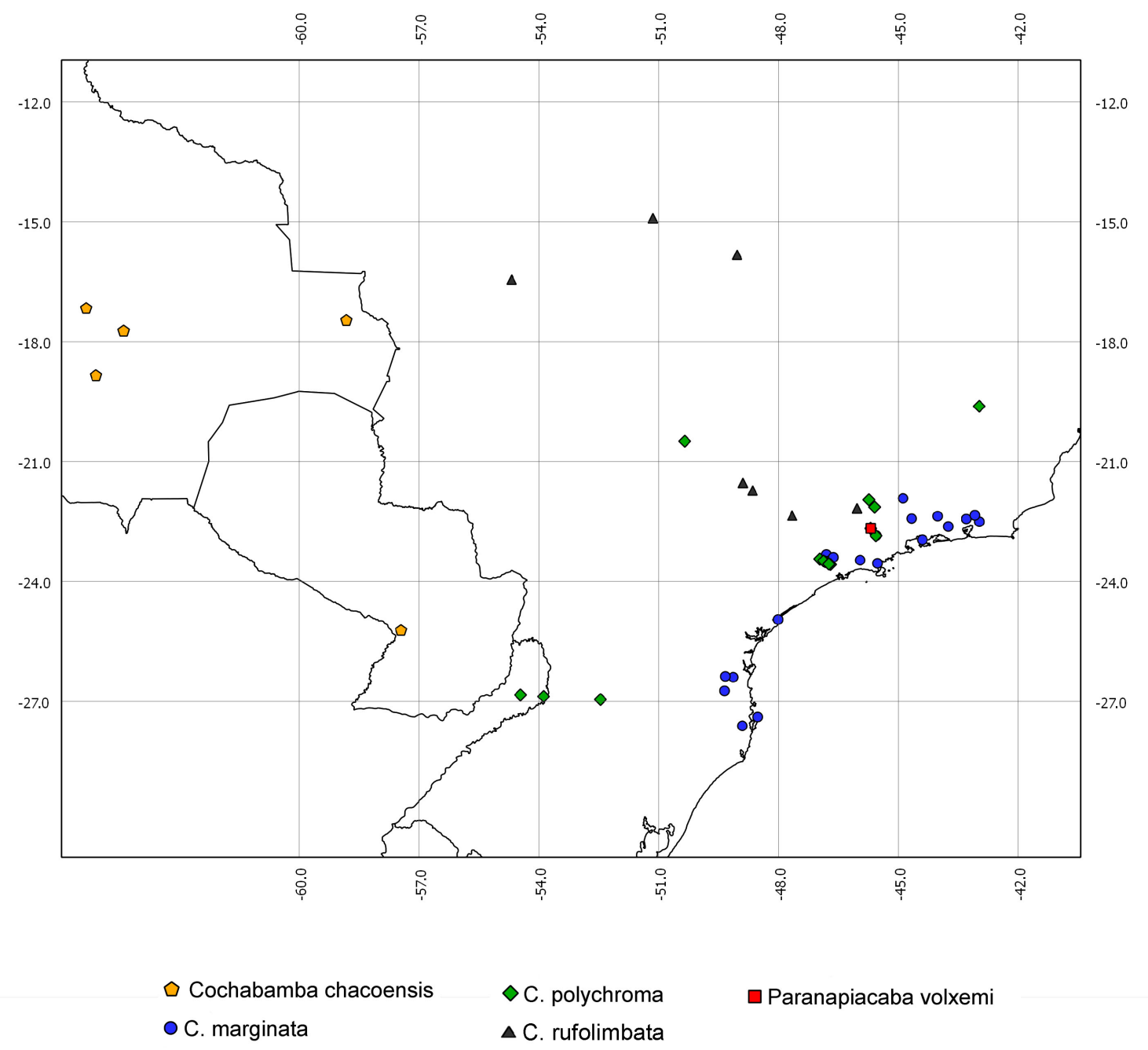

Figura 24: Distribuição geográfica das espécies de Cochabamba e Paranapiacaba volxemi, baseada nas etiquetas dos exemplares examinados e em informações da literatura: detalhe do sudeste da América do Sul. 